$M_{2016}$

\title{
PREVENTION OF INTRAVASCULAR CATHETER-RELATED INFECTIONS
}

MICAELA ALEXANDRA MACHADO QUERIDO

DISSERTAĈ̃O DE MESTRADO APRESENTADA

À FACULDADE DE ENGENHARIA DA UNIVERSIDADE DO PORTO EM ENGENHARIA BIOMÉDICA 


\title{
U.PORTO
}

FEUP FACULOADE de ENGENHARIA

UNIVERSTIDMDE DO PORTO

\author{
A Dissertação intitulada \\ "Prevention of Intravascular Catheter-Related Infections"
}

foi aprovada em provas realizadas em 11-07-2016

o júri

Presidente Prof. Doutor(Jorge Alves da Silva
Professor Auxiliâr do Departamento de Engenharia Informática da FEUP - Uporto

Salotte Reis

Prof. ${ }^{a}$ Doutora Maria de La Salette de Freitas Fernandes Hipólito Reis Dias Rodrigues

Professora Associada da Faculdade de Farmácia da U. Porto

Ceishe teouns

Doutora Maria Cristina Teixeira Lopes da Costa Pinto Lopes Martins

Investigadora do Instituto de Engenharia Biomédica - INEB - Uporto

o autor declara que a presente dissertação (ou relatório de projeto) é da sua exclusiva autoria e foi escrita sem qualquer apoio externo năo explicitamente autorizado. Os resultados, ideias, parágrafos, ou outros extratos tomados de ou inspirados em trabalhos de outros autores, e demais referências bibliográficas usadas, são corretamente citados.

Micalla Querida

Autor - Micaela Alexandra Machado Querido

Faculdade de Engenharia da Universidade do Porto 
Faculdade de Engenharia da Universidade do Porto

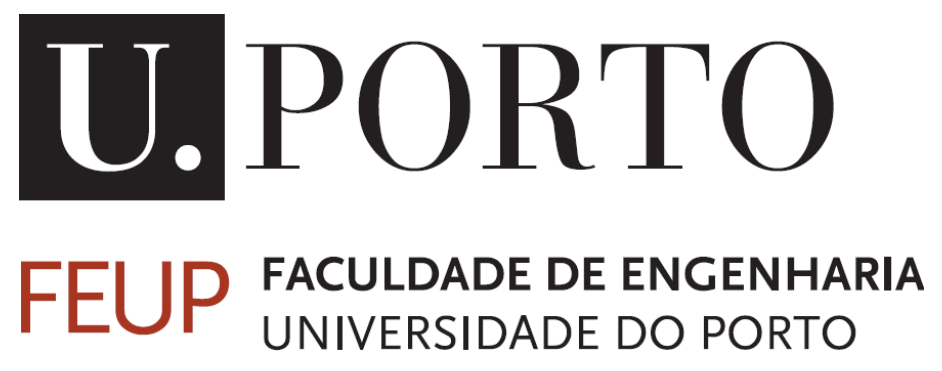

\title{
Prevention of intravascular catheter-related infections
}

\author{
Micaela Alexandra Machado Querido
}

Master Degree Dissertation

Master Degree in Biomedical Engineering

Supervisor: Dr. M. Cristina L. Martins

Co-supervisor: Dr. Helena Felgueiras

Co-supervisor: Dr. Lino Ferreira 
๑) Micaela Alexandra Machado Querido, 2016 


\section{Sísifo}

\section{"Recomeça...}

Se puderes,

Sem angústia e sem pressa.

E os passos que deres, Nesse caminho duro

Do futuro,

Dá-os em liberdade.

Enquanto não alcances

Não descanses.

De nenhum fruto queiras só metade.

E, nunca saciado,

Vai colhendo

Ilusões sucessivas no pomar

E vendo

Acordado,

O logro da aventura.

És homem, não te esqueças!

Só é tua a loucura

Onde, com lucidez, te reconheças." 


\section{Acknowledgements}

Gostaria de agradecer a todas as pessoas de algum modo me ajudaram ou apoiaram durante esta incrível jornada.

Em primeiro lugar gostaria de agradecer à minha orientadora, Cristina Martins, por toda a ajuda, toda a partilha de conhecimento e todo o apoio durante a minha dissertação. Obrigada por me aceitar numa equipa tão fantástica, por me apresentar mundo da investigação, por todos os desafios, e por toda a confiança em mim e no meu trabalho.

Também tenho de verdadeiramente agradecer à minha co-orientadora, Helena Felgueiras por me apresentar e ensinar a maioria das técnicas que usei durante este trabalho de investigação. Obrigada pela paciência, pela imensa ajuda, pelo companheirismo e pelas horas infinitas que partilhámos no laboratório.

Os meus agradecimentos também se estendem ao meu co-orientador, Lino Ferreira e ao Akhilesh Rai por esta parceria, por me terem ajudado com as minhas amostras e por serem tão prestáveis.

Ao Centro Hospitalar de São João o meu agradecimento sincero por sempre me terem fornecido as plaquetas que usei no meu trabalho. Ao CEMUP-Centro de Materiais de Universidade do Porto o meu obrigado, especialmente ao Eng ${ }^{\circ}$. Carlos Sá pela ajuda com o XPS e à Daniela pelas longas horas que passámos juntas no SEM. Devo agradecer igualmente à Dalila Pedro por ter realizado ponto crítico nas minhas infinitas amostras, e ao Ricardo Vidal pelas diversas formações e por toda a ajuda. Obrigada a todos os outros técnicos do INEB e a todo o pessoal em geral que sempre me fez sentir tão bem integrada.

Tenho também de agradecer à minha incrível equipa por todo o apoio, toda a partilha e por me terem feito sentir sempre tão bem-vinda. 0 meu muito obrigada a todos e cada um de vós que de algum modo sempre me ajudaram quando precisei. Obrigada por toda a ajuda quer no laboratório quer na secretária, por me terem aceitado como uma de vós e pelos nossos fantásticos momentos fora do laboratório.

O meu especial agradecimento aos meus companheiros de guerra, Inês Borges, Luís Baptista e especialmente Diana Oliveira. Obrigada por toda a ajuda, pela paciência, pelos desabafos e pelas noitadas na câmara de fluxo.

Obrigada aos meus amigos de Alcobaça que sempre me apoiaram e me deram força para levar este projecto avante nos bons e maus momentos. Igualmente obrigada a todos os meus 
amigos e companheiros da Covilhã por três anos fantásticos e por terem partilhado comigo o início do que viria a ser uma grande aventura.

Obrigada à minha família do Porto, João Brás, Stéphanie Soares, João Rufo, Joana Gomes e Sandra Campos por todo o apoio, pela amizade, pelos jantares, pelos cafés e pelos debates científicos quando assim tinha de ser. Um especial agradecimento ao meu companheiro e amigo de longa data João Brás pelo apoio, pela partilha desta jornada e por termos estado juntos nisto até ao fim.

Obrigada a todos os meus vizinhos e amigos que de algum modo me apoiaram nem que fosse com palavras de incentivo quando ia a casa aos fins-de-semana, obrigada por sermos uma pequena grande aldeia e por toda a confiança que de algum modo depositaram em mim.

O meu agradecimento final mas não menos importante vai para toda a família que sempre me apoiou e incentivou a querer mais e melhor, a ser mais e melhor. Aos meus pais, Susana e Paulo, obrigada pelos sacrifícios que fizeram para que eu pudesse alcançar os meus sonhos e objectivos, por sempre acreditarem em mim e por sempre terem compreendido quando eu precisava de ir mais longe. Obrigada ao meu irmão André, por estar sempre lá para mim, por ser quem é, e pelo apoio incondicional. Obrigada aos meus avós, Maria e António e aos meus bisavós, Gracinda e José Clementino, por nunca terem duvidado de mim ou das minhas capacidades mesmo que nem sempre seja muito fácil compreender bem aquilo que faço. Obrigada ao meu avô José Machado, meu fã número um, e a primeira pessoa que me fez sonhar e acreditar que eu podia ser e fazer tudo aquilo que eu quisesse se apenas trabalhasse para isso.

A todos vocês, o meu sincero obrigado pela ajuda e incentivo ao longo desta incrível etapa. 



\section{Resumo}

As infecções e formação de trombos são dois graves problemas associados à utilização de cateteres intravasculares em terapias de longa duração [1]. As estratégias que têm sido utilizadas, particularmente o revestimento de cateteres com antibióticos ou outros bactericidas e com anticoagulantes, não são suficientemente eficazes para a resolução destes problemas [2].

Este trabalho de investigação teve como objectivo o desenvolvimento de revestimentos antimicrobianos para cateteres intravasculares, de modo a evitar infecções sem induzir a formação de trombos. Para tal, péptidos antimicrobianos (AMPs) foram 1) imobilizados covalentemente na superfície de filmes de poliuretano (PU) ou 2) incorporados durante a formação do filme. O Pellethane 2363-80 AE, foi o PU utilizado neste estudo por ser um dos polímeros mais utilizados na produção de cateteres intravasculares devido às suas propriedades físicas versáteis e à sua hemocompatibilidade [3].

Durante a primeira estratégia, o péptido Cecropin-Melittin (CM) foi covalentemente imobilizado na superfície do PU usando nanopartículas de ouro (Au NPs) como agente de ligação. A imobilização do $C M$ foi avaliada por espectroscopia de fotoelectrões de raios-X (XPS), medição de ângulos de contacto, elipsometria e espectroscopia de infravermelhos por transformada de Fourier com reflectância total atenuada (ATR-FTIR) e quantificada por espectroscopia Ultravioleta/Visível. A estabilidade do revestimento foi estudada utilizando a microbalança de cristal de quartzo com dissipação (QCM-D) em condições de fluxo. Os estudos de eficácia foram realizados utilizando uma estirpe de Staphylococcus epidermidis ( $S$. epidermidis) produtora de biofilme que foi clinicamente isolada de um cateter infectado [1]. A adesão bacteriana e a viabilidade das bactérias aderidas foram quantificadas por microscopia de fluorescência. $O$ efeito do $C M$ imobilizado na adesão e ativação de plaquetas foi calculado por microscopia electrónica de varrimento (SEM). Estes estudos foram realizados na presença e ausência de plasma humano para avaliar a influência da adsorção de proteínas na eficácia do revestimento. A adsorção de proteínas do plasma nas superfícies desenvolvidas foi quantificada utilizando a QCM-D.

Os resultados demonstraram que o CM foi imobilizado na superfície de PU com uma concentração aproximada de $68 \mu \mathrm{g} / \mathrm{cm}^{2}$. O revestimento com $\mathrm{CM}$ revelou-se estável sob condições de fluxo e foi capaz de reduzir a adsorção de proteínas do plasma no PU. O CM 
imobilizado diminuiu a adesão bacteriana ao PU e foi capaz de matar as bactérias aderidas mesmo na presença de proteínas do plasma. Este revestimento reduziu a adesão de plaquetas ao PU, contudo a pré-adsorção de proteínas do plasma aumentou, de forma não significativa, o número de plaquetas aderidas ao material com CM mas diminui o seu grau de ativação.

Relativamente à segunda estratégia, MSI-78 (1-17) e MSI-78 (2-18), dois pequenos AMPs derivados do comercial e muito eficiente pexiganan (MSI-78) [4], foram incorporados em filmes de PU durante a sua produção para criar um sistema de libertação de péptidos no local da infecção. A atividade antimicrobiana destes filmes contra S. epidermidis foi avaliada na presença/ausência de plasma humano através da contagem do numero de bactérias viáveis após contacto com a superfície (Unidades formadoras de colónias (CFUs)/mL).

Os resultados de eficácia demonstram que ambos os filmes com péptidos têm efeito bactericida contra esta bactéria mesmo quando produzidos com baixas concentrações de péptidos, tanto na presença como na ausência de plasma humano.

Os resultados desta investigação são bastante promissores sugerindo que a imobilização na superfície ou a incorporação de AMPs em biomateriais pode ser uma boa estratégia para prevenir infecções sem induzir a formação de trombos.

Palavras-chave: cateteres, infecção, formação de trombos, péptidos antimicrobianos 


\section{Abstract}

Infection and thrombus formation remain the major problem associated with the use of long-term intravascular catheters [1]. Strategies based on catheters coated with antibiotics or other bactericides and heparin are not enough to solve these problems [2].

This research work aims the development of antimicrobial coatings, which can be applied in intravascular catheters, to avoid infections without inducing thrombus formation. For that, two strategies were followed based on 1) covalent immobilization or 2) physical incorporation of Antimicrobial Peptides (AMPs) on polyurethane (PU). Pellethane 2363-80 AE was the PU was selected for this study due to its application in the production of intravascular catheters, its versatile physical properties and hemocompatibility [3].

During the first strategy, the peptide Cecropin-Melittin (CM) was covalently immobilized onto the surface of PU films using gold nanoparticles (Au NPs) as binding agent. Surface immobilization was evaluated using X-ray photoelectron spectroscopy (XPS), contact angle measurements, ellipsometry and ATR-FTIR and CM was quantified using Ultraviolet-Visivel spectroscopy analysis. Stability of the CM coatings was evaluated in flow conditions using quartz crystal microbalance with dissipation (QCM-D).

Efficacy studies were performed using a strain of Staphylococcus epidermidis ( $S$. epidermidis) that is high slime producer and was isolated from an infected catheter [1]. These studies were performed in the presence/absence of human plasma to evaluate the influence of plasma proteins adsorption of CM coating efficacy. Plasma protein adsorption to the developed surfaces was quantified using QCM-D. The influence of immobilized CM on platelet adhesion and activation was also performed in the presence/absence of human plasma.

Results demonstrated the successful of CM immobilization on PU surface $\left(68 \mu \mathrm{g} / \mathrm{cm}^{2}\right) . C M$ coating was stable under flow conditions and decreases the adsorption of plasma proteins to PU. Immobilized CM was able to decrease bacterial adhesion to PU and to kill adherent bacteria even in the presence of plasma proteins. CM coating also decreased platelet adhesion to PU. However, adsorbed plasma proteins slightly increased the number of adherent platelets on the CM-coating but decreased their degree of activation. 
Concerning the second strategy, MSI-78 (1-17) and MSI-78 (2-18), two shorter AMPs derived from the commercial and very efficient pexiganan (MSI-78) [4], were incorporated in PU films during its production to create a local delivery system. The antimicrobial activity of these films was evaluated against S. epidermidis in the presence/absence of human plasma by (Colony forming units (CFUs)/mL) counting.

Efficacy results demonstrated that both peptides have bactericidal effect against the bacteria even when incorporated in low concentrations, both in presence and absence of human plasma.

The results of this research sound quite promising suggesting that AMPs immobilization or incorporation in biomaterials could be a good strategy to prevent infections without inducing thrombus formation.

Keywords: catheters, infection, thrombus formation, antimicrobial peptides 



\section{Index}

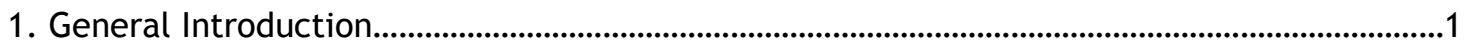

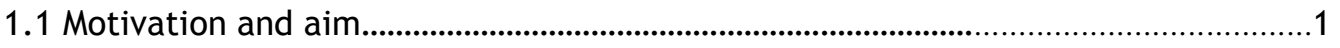

1.2 Structure of the Dissertation.......................................................................................2

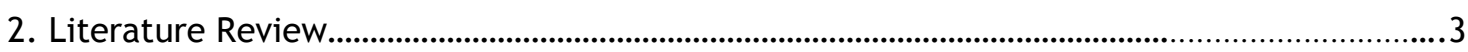

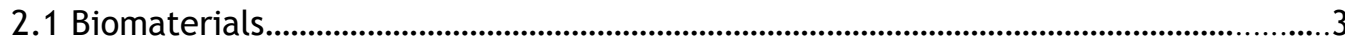

2.1.1 Polymers for Intravascular Catheters .....................................................

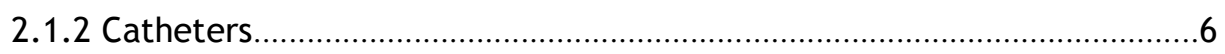

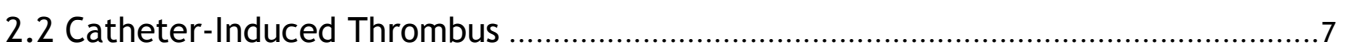

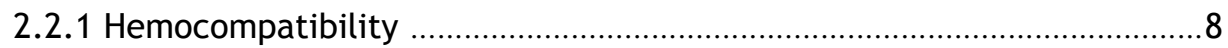

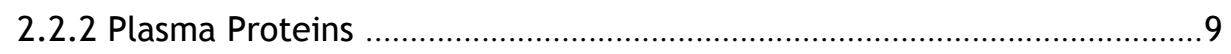

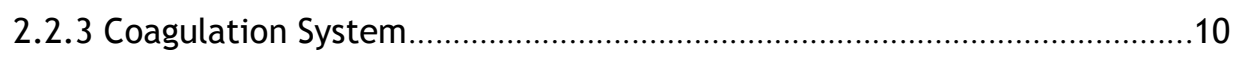

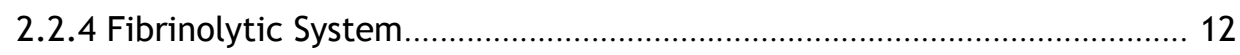

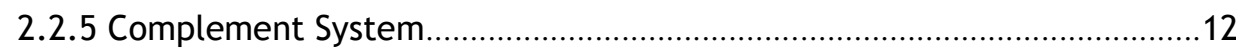

2.2.6 Interaction of Blood Cells with Biomaterials..........................................13

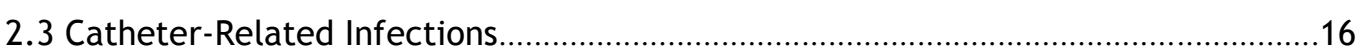

2.3.1 Bacterial Adhesion and Biofilm Formation................................................17

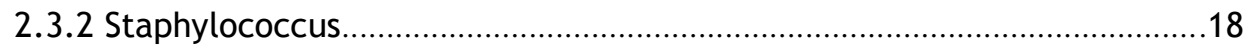

2.3.3 Strategies to Treat and Prevent Catheter-Related Infections..................20

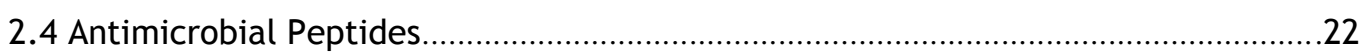

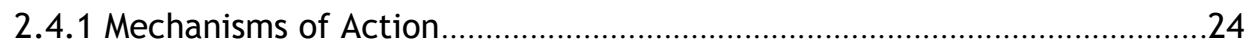

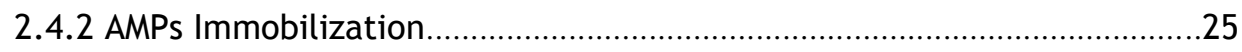

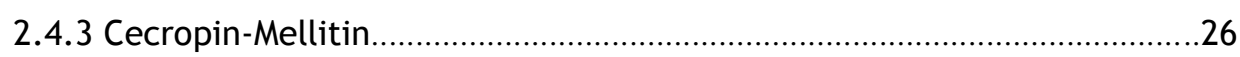

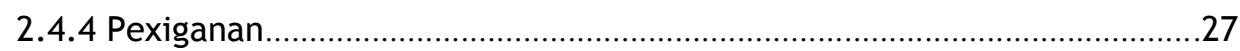

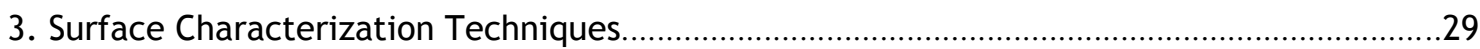

3.1 Scanning Electron Spectroscopy.......................................................................................29

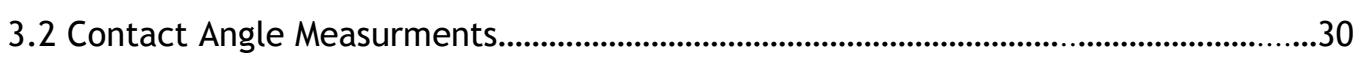

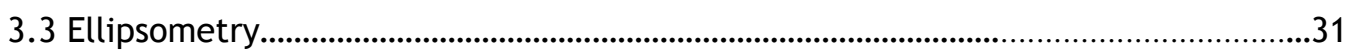

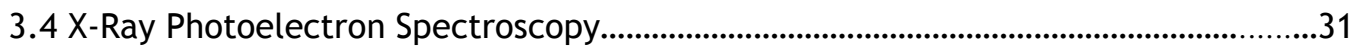


3.5 Attenuated Total Reflection - Fourier-Transform InfraRed

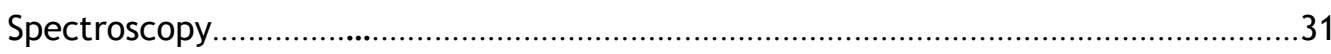

3.6 Quartz Crystal Microbalance with Dissipation........................................................33

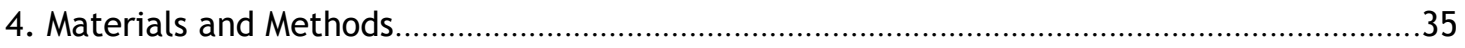

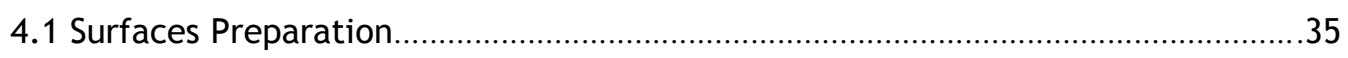

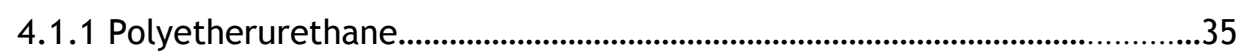

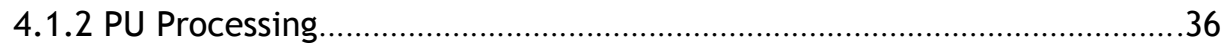

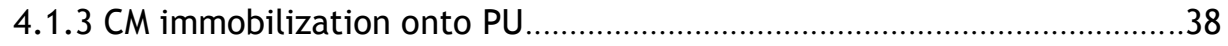

4.1.4 Physical Incorporation of MSI-78-derived Peptides into PU Films..............40

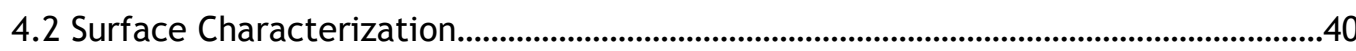

4.2.1 Scanning Electron Spectroscopy ...........................................................40

4.2.2 Water Contact Angle Determination.........................................................40

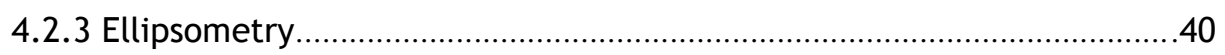

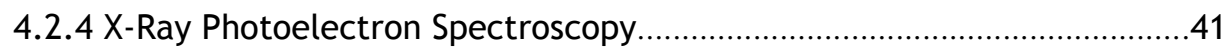

4.2.5 Attenuated Total Reflection-Fourier Transform InfraRed Spectroscopy.41

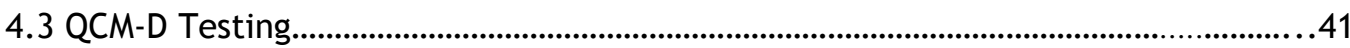

4.3.1 Stability of Au NPs and CM Coating................................................................41

4.3.2 Adsorption of Blood Plasma.............................................................................42

4.4 Platelets Adhesion and Activation..................................................................................42

4.5 Antimicrobial and Anti-Adhesive Properties of CM Coatings ........................................43

4.5.1 Bacteria Strains and Growth Conditions .........................................................43

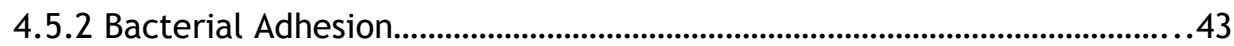

4.5.3 Bacteria Viability.................................................................................................43

4.6 Antimicrobial Activity of PU Films Containing MSI-78 (1-17) and MSI-78 (2 18).....43

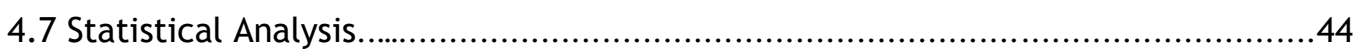

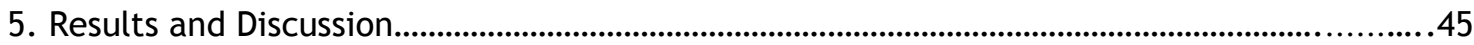

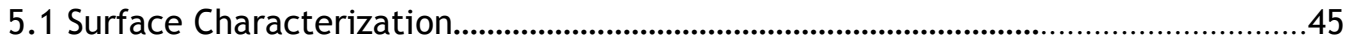

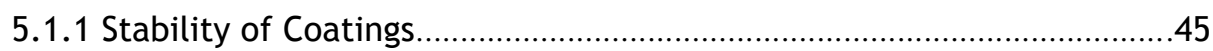

5.1.2 Scanning Electron Spectroscopy .................................................................4

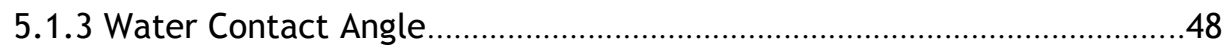

5.1.4 Thickness of Coatings: Ellipsometry.................................................................48

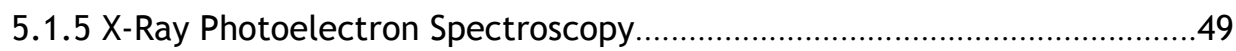

5.1.6 Attenuated Total Reflection-Fourier Transform InfraRed Spectroscopy.51

5.1.7 Immobilized CM quantification.....................................................................51

5.2 Biological Testing..................................................................................................................52

5.2.1 Protein Adsorption .....................................................................................................52

5.2.2 Platelet Adhesion and Activation....................................................................53

5.2.3 Bacterial Adhesion to CM coating.......................................................................55 
5.2.4 Viability of Adherent Bacteria......................................................................57

5.3 MSI-78 (1-17) and MSI-78 (2-18) Antimicrobial Activity...................................................57

5.3.1 Antimicrobial Activity assay..............................................................................57

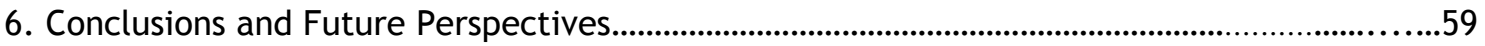

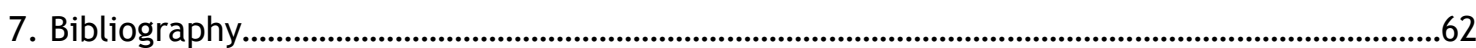




\section{List of Figures}

Figure 1- Standard two-step reaction to form PU.

Figure 1- (A) Central venous catheter made of PU, with a triple lumen. (B) Locals of insertion

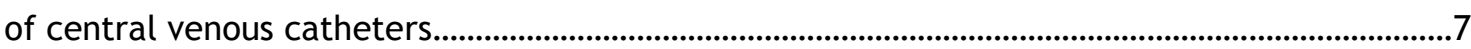

Figure 2 - Composition of human blood.......................................................................................................

Figure 3- (A) Structure of human serum albumin and (B) human fibrinogen..........................................10

Figure 5- Pathways of activation of coagulation cascade...................................................................................11

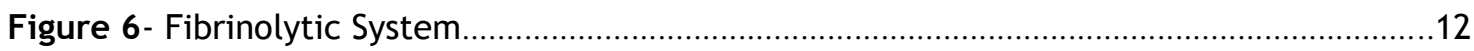

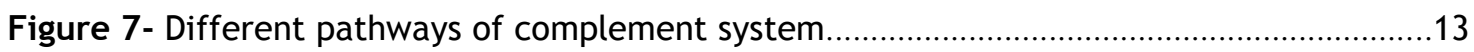

Figure 8- Platelet adhesion, activation and aggregation processes......................................15

Figure 9- Incidence of microorganisms in central venous catheter-related infections..............16

Figure 10- Different phases of biofilm formation and maturation......................................18

Figure 11- Cell wall of Gram negative (A) and Gram positive bacteria (B) .......................................19

Figure 12- Staphylococcus epidermidis. Original scanning electron microscopy (SEM) image at

magnification 10,000x....................................................................................................................................................20

Figure 13- Surfaces with bactericidal effect by direct contact $(A)$ and by release from the surface (B). (C) Surface with non-fouling properties...............................................................................21

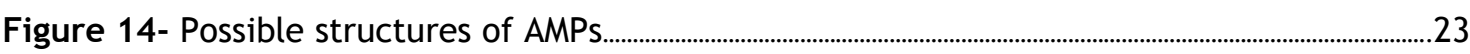

Figure 15- Mechanisms of action of membrane-active AMPs: carpet, toroidal pore and barrel-

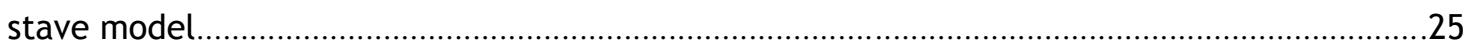

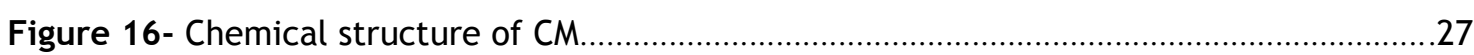

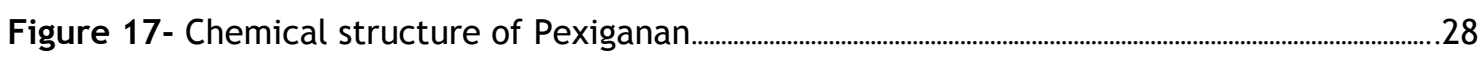

Figure 18- SEM equipment $(A)$ and schematic representation of its components (B)..................30

Figure 19- Contact angle measurement equipment (A). Contact angle observed in a

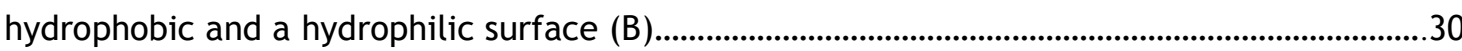

Figure 20- Ellipsometer equipment (A). Schematic representation of the ellipsometer setup

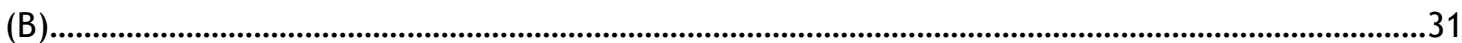

Figure 21- XPS equipment (A). Schematic representation of XPS components in detail (B)...32

Figure 22- ATR-FTIR equipment (A). Schematic representation of sample analysis with ATR-

FTIR spectroscopy (B).

Figure 23- QCM-D equipment (A). Schematic representation of a QCM-D crystal and sensing principle (B)

Figure 24- Gold substrate and sensor on which PU ultra thin films were produced and PU film

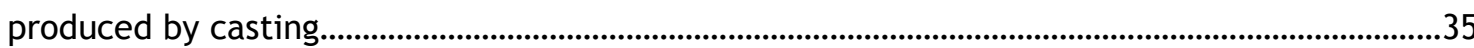

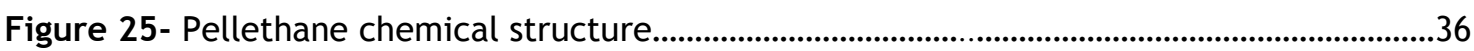

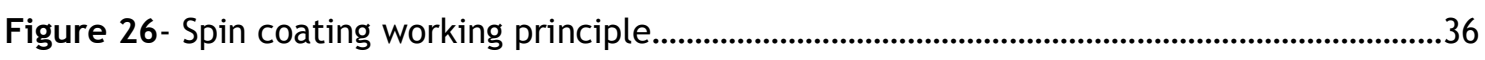

Figure 27- Gold coated silicon wafer where gold subtracts were extracted from........................37

Figure 28- Flow module of a QCM-D with an 0-ring and a gold sensor..........................................38

Figure 29- Schematic representation of the PU surfaces modification with Au NPs and CM (A). Final scheme of CM immobilization on PU (B). PU films before (PU) and after surface modification (PU-Au NPs and PU-Au NPs-CM) (B)

Figure 30 - SEM images illustrating the five types of platelet shapes, from less activated to the most activated state. round or discoid (R); dendritic or early pseudopodial (D); spreaddendritic or intermediate pseudopodial (SD); spread or late pseudopodial (S) and fully spread (FS). 
Figure 31- (A) PU-Au NPs and Pu-Au NPs-CM (B) stability profiles from $7 \mathrm{~h}$ injection of PBS at different speeds (from 12.5 to $200 \mu \mathrm{L} / \mathrm{min}$ ) in PU_ChA and PU_U . (C) Total mass changes registered on the surfaces in PU_ChA and PU_U. Positive values correspond to mass loss and negative values correspond to mass accumulation, on the sensor................................................46

Figure 32- Surface morphology of PU, PU-Au NPs and PU-Au NPs-CM obtained by SEM at 2,000x and 200,000xmagnification

Figure 33- (A) Water optical contact angles of the surfaces PU, PU-Au NPs and PU-Au NPs-CM. (B) Appearance of water drop in contact with the each surface.

Figure 34 - (A) Results from ellipsometry on PU and PU-Au NPs. (B) Aspect of the surfaces during ellipsometry assay

Figure 35- FTIR-ATR spectra of PU, PU-Au NPs and PU-Au NPs-CM.......................................51

Figure 36- $(A, B, C)$ QCM-D protein adsorption profiles from $1 \%$ human plasma in PBS on PU, Au NPs and CM. (D)Total amount of proteins adsorbed from 1\% human plasma in PBS on PU, Au NPs and CM

Figure 37 - Adhesion of human platelets on PU, PU-Au NPs and PU-Au NPs-CM. Surfaces were pre-immersed in PBS or $1 \%$ human plasma.

Figure 38 - Platelet shape distribution on PU, PU-Au NPs and PU-Au NPs-CM. Surfaces were pre-immersed in PBS (A) or 1\% human plasma (B)

Figure 39- Representative images of platelets adhesion and activation in contact with PU and PU-Au NPCM surfaces in the presence of PBS and 1\% human plasma. Images were obtained by SEM at 2,000x magnification .55

Figure 40- Total number of adherent bacteria on PU, PU-Au NPS and PU-Au NPs-CM...............56 Figure 41- Representative images of bacteria adhesion to PU and PU-Au NP-CM surfaces in the presence of PBS and 1\% human plasma. Images were obtained by MIF at 100x with oil, $20 \mu \mathrm{m}$ scale

Figure 42- Comparison between total and dead adhered bacteria. .57

Figure 43- Number of CFUs after contact with the surfaces (bacteria solution in PBS) (A). Number of CFUs after contact with the surfaces (bacteria solution in 1\% human plasma) (B). 58 


\section{List of Tables}

Table 1- Catheter occlusions induced by fibrin deposition..............................................................

Table 2- Surface atomic composition (\%) of the different samples calculated from highresolution XPS spectra.......................................................................................................................50

Table 3- Surface composition (\%) of Carbon and Sulfur calculated from high-resolution XPS spectra . .50 


\section{Abbreviation and Symbols}

\begin{tabular}{|c|c|}
\hline PU & Polyurethane \\
\hline AMP & Antimicrobial Peptide \\
\hline CM & Cecropin-Melittin \\
\hline Au NPs & Gold Nanoparticles \\
\hline QCM-D & Quartz Crystal Microbalance with Dissipation \\
\hline XPS & X-ray Photoelectron Spectroscopy \\
\hline S. epidermidis & Staphylococcus epidermidis \\
\hline MSI-78 & Pexiganan \\
\hline Factor XII & Hageman factor \\
\hline HMWK & High molecular weight kininogen \\
\hline TF & Tissue factor \\
\hline vWF & von Willebrand factor \\
\hline S. aureus & Staphylococcus aureus \\
\hline PEG & Poly(ethylene glycol) \\
\hline SEM & Scanning Electron Microscopy \\
\hline FTIR-ATR & Attenuated Total Reflection- Fourier-Transform InfraRed Spectroscopy \\
\hline RT & Room Temperature \\
\hline PP & Polypropylene \\
\hline THF & Tetrahydrofuran \\
\hline $\mathrm{HAuCl}_{4}$ & Chloroauric Acid \\
\hline STC & Silicon tetrachloride \\
\hline APTMS & 3-amino propyltrimethoxysilane \\
\hline sulfo-GMBS & $\mathrm{N}$-[Y-maleimidobutyryloxy]sulfosuccinimide ester solution \\
\hline sulfo-SDTB & Sulfosuccinimidyl-4-o-(4,4-dimethoxytrityl)butyrate \\
\hline $\mathrm{C}$ & Carbon \\
\hline N & Nitrogen \\
\hline 0 & Oxygen \\
\hline$s$ & Sulfur \\
\hline
\end{tabular}


Phosphate buffered saline solution

PU_U

PU unmodified

PU_ChA

PU chemically activated

BSA

Bovine serum albumin

$\mathrm{R}$

Round

Dendritic

SD

Spread-dendritic

$S$

Spread

FS

Fully spread

TSA

Trypticase soy agar

TSB

Trypticase soy broth

DAPI

4',6- diamidino-2-phenylindole

$\mathrm{NaCL}$

Sodium Chloride 


\section{Oral and Poster Communications based on this Master Dissertation:}

1) Querido MM, Rai A, Felgueiras HP, Ferreira L, Martins MCL. "Influence of CecropinMelittin antimicrobial coating in platelet adhesion/activation to biomaterials" in "IV International Conference on Antimicrobial Research"- Málaga, Spain (July 2016, Poster);

2) Querido MM, Rai A, Felgueiras HP, Ferreira L, Martins MCL. "Influence of CecropinMelittin antimicrobial coating in platelet adhesion/activation to biomaterials" in " $7^{\text {th }}$ Symposium on Bioengineering- Faculdade de Engenharia da Universidade do Porto" Porto, Portugal (April 2016, Poster);

3) Querido MM, Felgueiras HP, Martins MCL. "Influence of Human Blood Plasma in Bacteria and Platelet Adhesion to Biomaterials" in "IJUP-Encontro de Investigação Jovem da Universidade do Porto, $9^{\text {th }}$ edition"- Porto, Portugal (February 2016, Oral Presentation). 



\section{Chapter 1}

\section{General Introduction}

\subsection{Motivation and Aim}

The major goal of this dissertation is the development of antimicrobial strategies to be applied in PU intravascular catheters in order to avoid infections, without inducing thrombus formation.

For that, the peptide CM was covalently immobilized on PU surfaces, using Au NPs as a bidding agent.

At the same time other AMPs, MSI-78 derivatives were incorporated in PU films during their production and their bactericidal effect was also studied.

The use of intravascular catheters is a very common and frequent medical procedure. Catheters are used during surgeries, therapeutic delivery, fluids removal, etc. Despite their continuous use, complications associated with their long-term utilization still occur, commonly in the form of thrombus formation and infections.

Once implanted in the human body, a biomedical device is quickly surrounded by a layer of adsorbed proteins and glycoproteins. These adsorbed proteins can initiate the intrinsic coagulation system and induce the adhesion, activation and aggregation of platelets that culminate in formation of blood clots. In the most serious scenarios, these clots can be released from the catheter, migrate through the blood vessels and cause a distant thrombus (thromboembolism), leading to the obstruction of blood vessels creating serious problems that may culminate in patient's dead [5]. More frequently, thrombus formation can also occlude the catheter tube requiring its consequent removal/replacement. Conventional strategies to prevent thrombus formation include heparin administration. However, haemorrhage complications associated with the use of heparin is problematic for some patients, particularly for patients with traumas or wounds [6][7].

Catheter-related infection is also associated with the adsorbed protein layer that will mediate bacterial adhesion to the surface of the catheter. This type of infection is usually caused by bacteria, present in the patients' skin or in the hospital environment that after adhering to the catheters surface, can generate biofilms highly resistant to conventional antibiotic treatments [8]. Moreover, the increasing number of bacteria strains capable to become resistant to conventional antibiotics makes catheter-related infections very difficult 
to treat. Therefore, infection scenario frequently leads to implant removal/replacement, which aside from endangering patients' health also involves important economical costs [9].

Because of the limitations of the current strategies available, research has been conducted to develop catheters with antimicrobial coatings and better hemocompatibility. The immobilization of AMPs, with increased performance over classic antibiotics, on the surface of catheters is a promising approach to overcome these issues [10]. Yet, the efficiency of these antimicrobial surfaces in contact with human blood and its bacterial fighting skills are still poorly studied and require attention.

\subsection{Structure of the Dissertation}

In this dissertation, a complete literature review was prepared, exposing the most relevant and recent information on the subject in study.

The most frequent types of biomaterials used in cardiovascular applications, namely in catheters, blood composition and its effect on the hemocompatibility of catheters, along with information on thrombus formation are some of the subjects discussed in the Chapter 2 . In the same chapter is also possible to find information about catheter-related infections and the main bacteria involved in those infections, as well as a new strategy to overcome those problems, the utilization of AMPs. Types of AMPs, classifications, and mechanisms of actions are explored.

Chapter 3 presents some of the surface characterization techniques used in this work. Theoretical fundaments, practical applications and operating mode of the different techniques are briefly exposed.

Materials and methods used in the practical work can be found in Chapter 4 and the obtained results in Chapter 5, as well as the discussion of the results acquired. In Chapter 6 the conclusions and future work are presented. 


\section{Chapter 2}

\section{Literature Review}

\subsection{Biomaterials}

Biomaterials are a set of materials, natural or synthetic, used in a medical devices to diagnose, treat, augment or replace damaged tissues, organs or function of the body [11]. They can be inserted in the human body for long periods of time (long-term applications) or for small/limited periods (short-term applications). Biomaterials should not induce abnormal host responses when implanted, namely inflammation, allergies and early rejection associated with toxicity [12], [13].

Depending on the application, biomaterials may have to be: bioinert, bioactive, biodegradable, bioresorbable, biofunctional, etc. Those requirements may also determine the physical and mechanical properties of the biomaterial: stiffness, elasticity, resistance to stress, composition, density, etc. [14]. Biomaterials should be capable of resisting high mechanical solicitation, corrosion, fracture and fatigue. The resistance to constant use and varying loading may also be determinant for a long-term success. The highest imposition to a biomaterial is that it should not fail as long as the host lives [15]-[17].

Biomaterials can be divided in four major classes: (1) composites, (2) ceramics, (3) metals, and (4) polymers.

(1) Composites: materials that contain two or more distinct components. Usually, they are divided in two phases, the matrix, which is the bulk continuous phase, and the reinforcement, which is the non-continuous phase and usually is formed by materials that possess superior mechanical or thermal properties, depending on the demands of the application [13], [18].

(2) Ceramics: non-metallic inorganic materials with limited range of formulations. Ceramics possess remarkable properties, great strength and stiffness, high resistance to corrosion and wear, and low density and hardness. However, ceramic components may exhibit low fracture toughness and sensibility to the presence of cracks or other defects. Because of that they are commonly applied in combination with metals [18], [19].

(3) Metals: if properly processed, this class of materials provides reliable long term implant performance in major load-bearing situations. Metals can be used for several cardiovascular applications, namely in stents and cardiac valves. In addition, the good 
electrical conductivity of metals favors their use for neuromuscular stimulation devices such as pacemakers [18], [20].

(4) Polymers: versatile class of biomaterials due to their inherent flexibility to be synthesized or modified to match the physical and mechanical properties of various human tissues and organs [21]. Polymers are organic materials, macromolecules that result from smaller structural units (monomers) and are often used to replace soft tissue. Indeed, polymers are commonly used in the production of cardiovascular devices, including intravascular catheters the subject of this work [22].

\subsubsection{Polymers for Intravascular Catheters}

As said before, polymers are composed of several monomers covalently bonded to form long molecular chains. Polymers usually possess oxygen, hydrogen and carbon in their chains.

Polymers can be of natural or synthetic origins. Natural polymers are the ones we find in nature, like cellulose, proteins, polysaccharides, etc., and can be produced by plants, animals, and microorganisms. Synthetic polymers are artificially produced in laboratory and can be classified in elastomers, thermoplastics and termosets. Elastomers (i.e. rubbers) are soft, yet resistant and they can be recycled. Thermoplastics, as polyethylene and polyurethane, suffer alterations in their shape under heat conditions being possible to mold them with high temperatures. In the other hand, thermosets (i.e. polyester) retain their strength and shape even when heated [23][24].

Polymers are usually generated from one of two polymerization reactions, addition or condensation. In addition reaction, monomers, all equal among them, are added together to form a polymer. In condensation the monomers used to form the polymer can be equal or different among them. In this reaction, monomers are combined and a simple molecule of water, methanol, carbon dioxide or acid chloride is removed [25].

If the monomers used to form the polymer are equal, they will form a homopolymer. However, if the polymer results from two or more different monomers, it is called a copolymer.

Some of the artificial polymers most used in biomedical applications are polytetrafluroethylene, polypropylene, polyamides, polyvinylchloride and poly(etherurethane) (i.e. a type of PU) [22].

As biomaterials, polymers are often applied in the fabrication of cardiovascular devices due to their mechanical and physical properties. Polymers are less thrombogenic than metals, have low production cost, and, because of their ductility, products with specific shapes can be easily manufacture [26]. This way, polymers can be safely used in the production of prosthetic heart valves, vascular grafts, artificial heart components, tubing, intra-aortic balloons, shunts, percutaneous leads and catheters [27], [28].

$\mathrm{PU}$ is one of the most used materials in medicine, namely polyetherurethane, since there are several types of PU. PU is not only used in catheters production but in diverse medical devices, lead insulators of pacemakers, heart valves, artificial organs, vascular prostheses, etc [22].

This thermoplastic polymer synthesis results from different monomers reaction so, it is classified as a copolymer. In its composition there are alternating sections of hard segments and soft segments. The hard segments (crystalline) are composed of a isocyanate and a low 
molecular weight diol chain extender (R1 from Figure 1). Soft segments (amorphous) are generally composed of various types of polyols [29].

In PU synthesis (Figure 1), first the isocyanate group from the diisocyanate compound reacts with the hydroxyl group of the soft segment polyol to form the prepolymer. The reaction between the isocyanate groups and the hydroxyl-terminated end groups results in urethane linkages. In the second step, the low molecular weight chain extender, diol, is used to link the prepolymer segments yielding a high molecular weight polymer [30] [31].

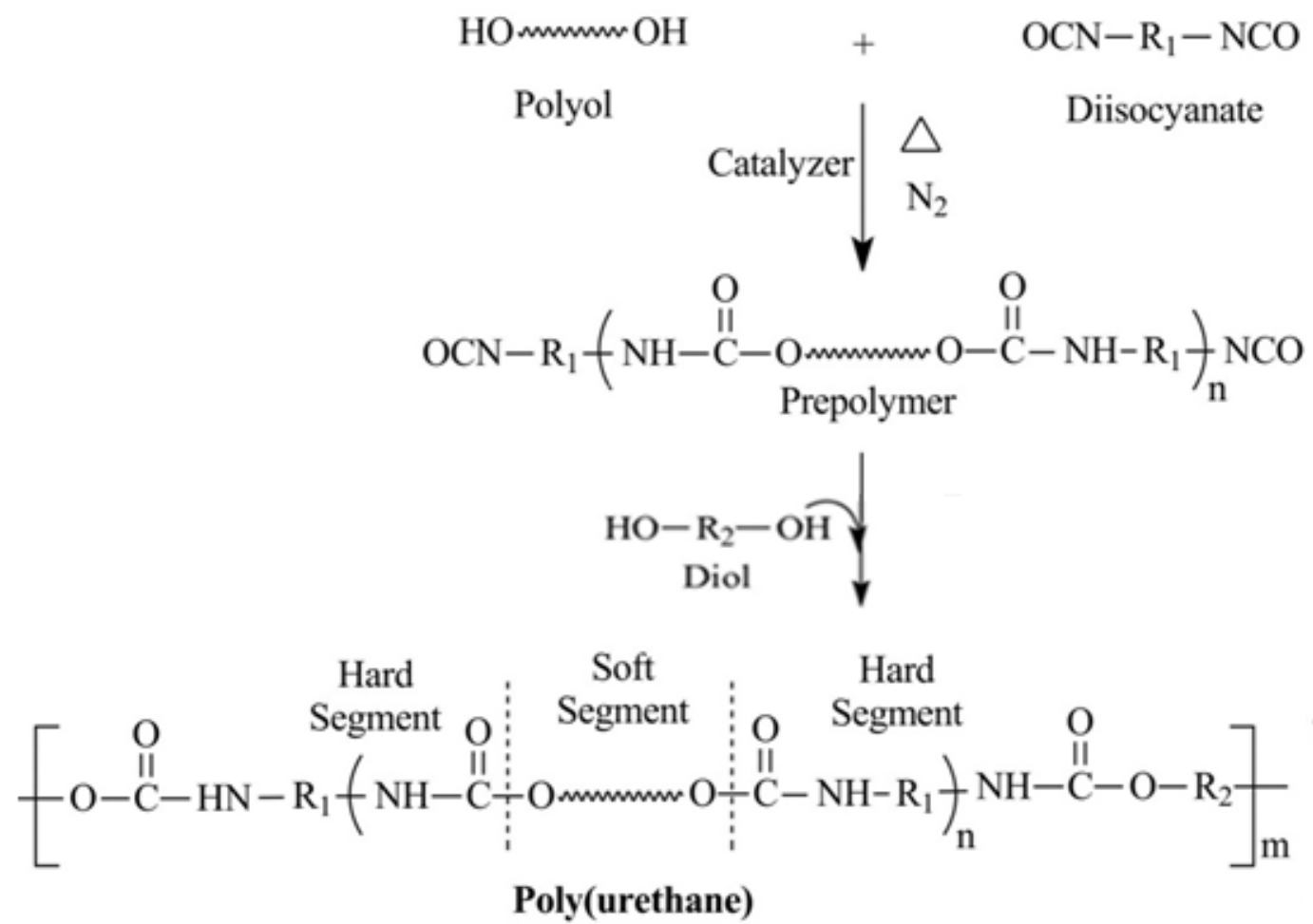

Figure 1- Standard two-step reaction to form PU. Adapted from [31]

The PU used in this research is Pellethane $236380 \mathrm{AE}$, a poly(ether-urethane) that results from the reaction of poly(tetramethylene oxide), methylene diphenyl diisocyanate and 1,4butanediol. The aromatic isocyanates, as methylene diphenyl diisocyanate, are well known for being highly reactive. These groups can be altered by light or temperature and they are responsible for PU stiffness. In this case the polyol used was poly(tetramethylene oxide) and 1,4-butanediol was the diol responsible for chain extender.

Some of the properties that make PU such a great biomaterial are its durability, elasticity, fatigue resistance and compliance, and its acceptance or tolerance by the human body [32]. Indeed, since PU was used in the fabrication of catheters, the thickness of the walls has been minimized, the flow maximized, the patients' comfort improved with a softer insertion, and the thromboresistive properties of the catheters have been ameliorated [33].

Although, it has been shown that PU have a low microbial colonization rate and better hemocompatibility in comparison to other materials [22] infection, thrombosis and inflammation related to PU vascular catheters, are still a problem. This is particularly important in catheters for long-term application that are often applied in patients with chronic diseases, whose immune system has been compromised and in need of prolonged drug delivery and fluids removal [34]. 


\subsubsection{Catheters}

Catheters are very thin tubes made of medical grade materials and can be used in a broad range of medical functions. These devices are inserted in the human body through cavities or through the vascular system, either to treat a disease or to perform a surgical procedure [35]. Catheters have many functions in medicine: therapeutic delivery, monitoring cardiovascular functions, removal of fluids and opening of blocked conduits [36].

There are different types of catheters according to the local of application, cardiovascular, urological, gastrointestinal, neurovascular and ophthalmic. In cardiovascular applications is possible to find pulmonary artery catheters, midline catheters, peripheral vascular catheters and central venous catheters, etc. [34]. Peripheral vascular catheters are divided in two types, venous and arterial, depending on the vessel where they are inserted. Peripheral venous catheters are the most frequently used in clinical practice to access the vascular system. Infections related to this sort of catheters have low incidence [34]. To the contrary, central venous catheters are responsible for a great number of bloodstream infections specially those applied in intensive care units, where most patients have impaired immune system [37] [30].

Central venous catheters (Figure 2 A) can be divided in: tunneled, non-tunnelled, implantable ports and peripherally inserted. Non-tunnelled catheters are made of PU or silicone and can be inserted in the neck through the jugular vein or in the peripheral venous system through the subclavian vein (Figure 2 B). These are short-term use catheters and do not require a surgical procedure. Tunnelled catheters, also made of PU or silicone, are of long-term use and are tunnelled surgically under the skin into the cannulated vein [40]. Implantable ports are devices that allow vascular access and are made of stable thermoplastic polymers (polysulfone) or titanium. These ports are surgically implanted beneath the skin and are connected to a catheter tube. The peripherally inserted central venous catheters, also made of PU or silicone, are inserted peripherally at or above the antecubital space, into the cephalic or basilic vein [38]. 


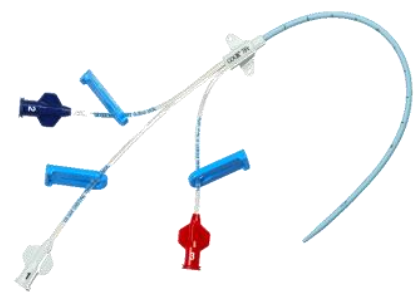

(A)

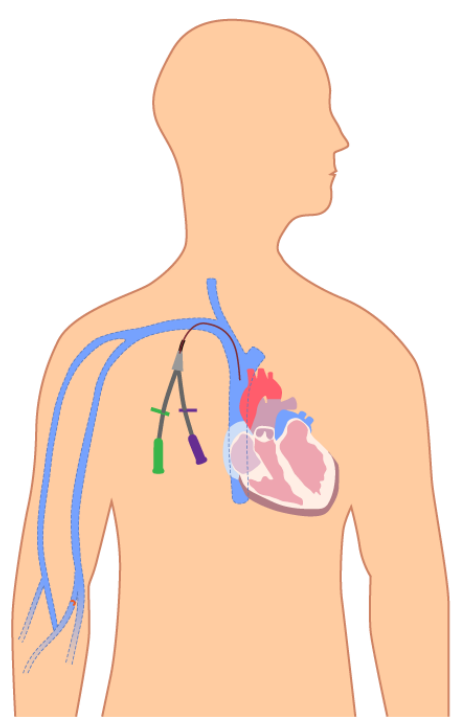

Subclavian vein insertion

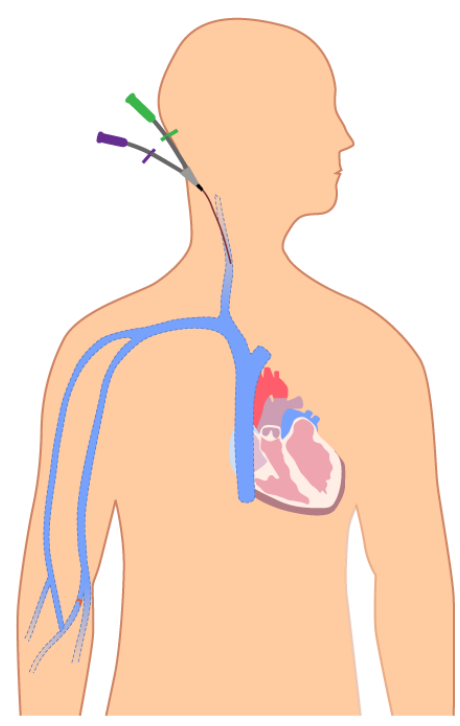

Internal jugular vein insertion

(B)

Figure 2- (A) Central venous catheter made of PU, with a triple lumen [42]. (B) Locals of insertion of central venous catheters [43].

The choice for the central venous catheter more appropriate for each situation depends on several aspects, the type of therapy or drug to be administered, duration of treatment, clinical situation of the patients, etc. Moreover, there are single and multiple lumen catheters of all types previously described. Multiple lumen catheters allow different medications to be administrated simultaneously without interference with the catheter tube. In here, different drugs can be infused in separate lumens, without contact [41].

\subsection{Catheter-Induced Thrombus}

After implantation adsorption of proteins and cells to the surface of catheters can generate thrombus [44].

Table 1 describes a series of catheter occlusions classified depending on how and where fibrin adheres to the surface. 
Inflammatory reaction may be provoked by a series of events involving proteins, platelets and leukocytes that by adsorbing onto the surface of the catheter lead to body responses as complement activation, coagulation, cellular recruitments, etc. [45], [46]. All those reactions are related to biomaterials, in this case catheters hemocompatibility.

Table 1- Catheter occlusions induced by fibrin deposition (adapted from [47]).

\begin{tabular}{|c||c|c||c|}
\hline \multicolumn{2}{|c|}{ Thrombotic Catheter Occlusions } \\
\hline \multicolumn{1}{|c|}{ Fibrin Tail } & Mural Thrombus & $\begin{array}{c}\text { Intraluminal } \\
\text { Thrombus }\end{array}$ & Fibrin Sheath \\
\hline $\begin{array}{c}\text { Fibrin adheres at the } \\
\text { end of the catheter } \\
\text { but is drawn inward, } \\
\text { blocking the opening } \\
\text { of the catheter lumen. }\end{array}$ & $\begin{array}{c}\text { Fibrin from a vessel } \\
\text { wall adheres to the } \\
\text { catheter covering the }\end{array}$ & $\begin{array}{c}\text { Fibrin adheres to the } \\
\text { lumen of the catheter }\end{array}$ & $\begin{array}{c}\text { Forms when fibrin } \\
\text { adheres to the } \\
\text { whenternal catheter }\end{array}$ \\
\hline
\end{tabular}

\subsubsection{Hemocompatibility}

Hemocompatibility relates to the specific interactions between a biomaterial and blood [44].

The human body contains about 5 liters of blood. In its composition red blood cells, leukocytes, platelets and plasma ( $\approx 55 \%$ of total blood) can be found (Figure 3 ). Red blood cells exhibit a biconcave disk-like shape and are responsible for the transport of oxygen within the bloodstream. White blood cells or leukocytes have very important functions in the immune system eliminating invader pathogens by capturing them or by producing antibodies. Platelets, also known as thrombocytes, are anucleate cells and their cytoplasm is surrounded by a plasmatic membrane. They are involved in blood clot formation. Plasma is the main component of blood and is non-cellular. It is a junction of dissolved substances (2\%), proteins (7\%) and water (91\%). In the protein portion we can find proteins like albumin, globulin and fibrinogen: albumin maintains the osmotic balance of the organism by providing an isotonic 
solution for cells; globulins are important components of the immune system and bind to antigens on the surface of pathogens, defending the body; and fibrinogen has an important role in helping the formation of blood clots. The functions of plasma include the transport of these substances in the media, as they move throughout the body [48], [49].

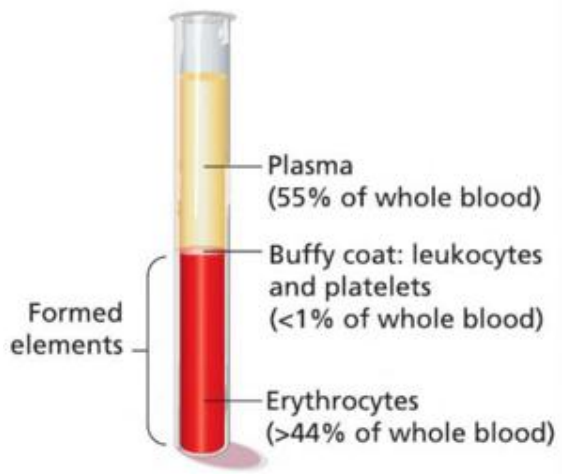

Figure 3 - Composition of human blood (adapted from [50]).

The reaction of human blood to a biomaterial is quite complex, it involves different mechanisms and elements, going from proteins to cells [51]. A material that does not provoke an adverse reaction from blood is categorized as hemocompatible and has higher chances of being accepted by the organism. Thus, improving the hemocompatibility of biomaterials has become a main concern of the scientific community. Indeed, new biological strategies have been engineered to enhance the biomaterials' hemocompatibility; the use of polysaccharides, "passivant" proteins, or even thrombotic inhibitors are very common options [52].

Hemocompatibility can be evaluated by the level of adhesion of cells to the biomaterial during contact with platelets, leukocytes or total blood [53]. The adsorption of plasma proteins is also important to define the hemocompatibility of a catheter, since protein adsorption on a biomaterial surface can trigger important bioresponses: plasma enzymes cascade activation (complement, fibrinolytic and coagulation systems), platelet activation, leukocyte activation or blood aggregation, responsible for thrombosis [54]. Adsorption of plasma proteins can also promote bacterial adhesion to polymeric surfaces, generating biofilms and, consequently, infections that culminate in the biomaterial removal or substitution [55].

\subsubsection{Plasma Proteins}

Plasma is the biggest component of the human blood. In its composition there are several proteins, including albumin, fibrinogen, globulins and other regulatory proteins, such as enzymes, proenzymes, and hormones.

Human serum albumin, present in plasma in a concentration around $40 \mathrm{mg} / \mathrm{mL}$ in human adults, is the most abundant plasma protein representing about $60 \%$ of total protein composition (Figure $4 \mathrm{~A}$ ). This protein is considered a very important mediator in biomaterial applications. Indeed, albumin has the ability to prevent bacterial and cell/platelet adhesion on polymer, ceramic and metal surfaces [56], by binding directly to bacteria or by increasing the hydrophilicity of the surface (albumin adsorbs preferentially onto hydrophobic surfaces). This way, adsorbed albumin reduces surface-blood interactions in biomaterials becoming an 
important agent in hemocompatibility, fighting inflammation, infection and thrombus formation [57].

Fibrinogen, also known as factor $\mathrm{I}$, is a glycoprotein produced in the liver in a plasmatic concentration of 2-4 g/L (Figure $4 \mathrm{~B}$ ) [58][59].

Fibrinogen, by the action of thrombin, can be converted into fibrin to form blood clots during hemorrhagic accidents. It also contributes to the activation and aggregation of platelets [51]. Because of that, fibrinogen adsorption onto biomaterial surfaces is a limiting factor of hemocompatibily. Moreover, it has been shown that fibrinogen may induce inflammatory events on biomaterial surfaces by increasing the recruitment and adhesion of leukocytes [60].

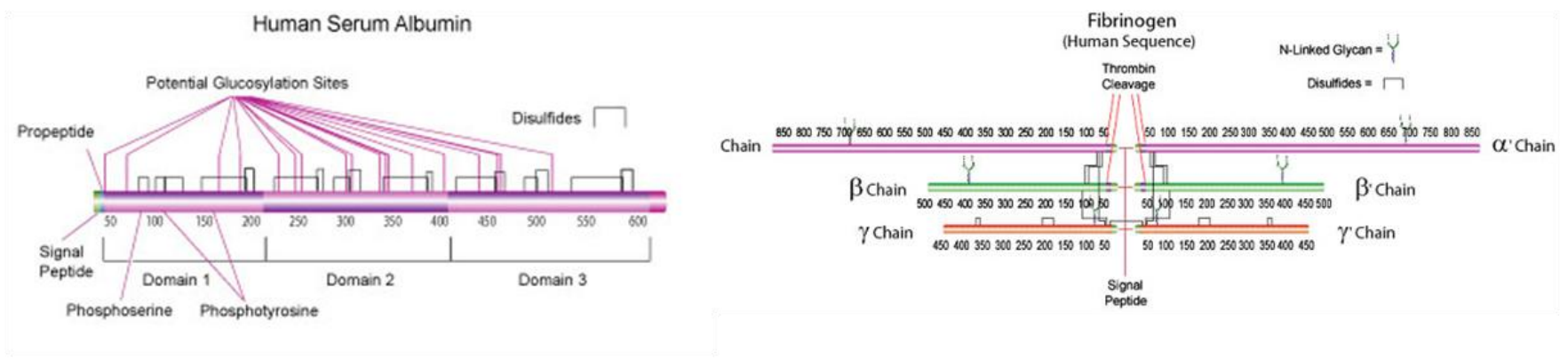

(A)

(B)

Figure 4- (A) Structure of human serum albumin [61] and (B) human fibrinogen [62].

\subsubsection{Coagulation System}

The coagulation system is responsible for maintaining hemostasis, or in other words to suspend hemorrhagic events. This process is directly correlated with the recruitment, activation and aggregation of platelets [63]. Indeed, when an injury is suffered and hemorrhage occurs, coagulation factors are activated to stop the bleeding by forming blood clots, coagulation [64]. Those clots are composed by a network of fibrin that retains platelets, blood cells and even fluids.

Coagulation system can also be activated by contact with a foreign surface, a biomaterial. The activation of coagulation proteins by a biomaterial starts with adsorption of plasma proteins, namely contact phase proteins as Hageman factor (factor XII), prekallikrein or high molecular weight kininogen (HMWK), on its surface. Factor XII when activated is also involved in the initiation of the fibrinolytic system (section 2.2.3) and the classic pathway in complement system (section 2.2.4) [65], [66].

Based on the event that promotes system activation, coagulation may occur in two ways: by intrinsic pathway or by extrinsic pathway (Figure 5). Intrinsic pathway is initiated when factor XII contacts with a material surface, particularly negatively charged surfaces like glass and some biomaterials by surface-mediated reactions. Although, factor XII can also be activated by contacting with activated platelets and damaged tissue. Extrinsic pathway is triggered by substances extrinsic to blood. Its stars when cells expressing tissue factor (TF) on its surface are exposed to blood components during an injury. TF will react with factor VII 
present in blood plasma, activate it into factor VIla and forming a complex TF/factor VIla that on its turn will activate factor IX and factor X [67].

Injured tissues or vessels can activate their coagulation factors by different ways; still, all result in prothrombinase formation. Prothrombinase converts prothrombin in thrombin, which not only converts fibrinogen into fibrin but also has a retro-positive action mechanism that allows for more thrombin to be produced. Prothrombinase and thrombin can also stimulate factor XIII activation that has an important role in stabilizing fibrin clot as schematized in Figure 5 [68].

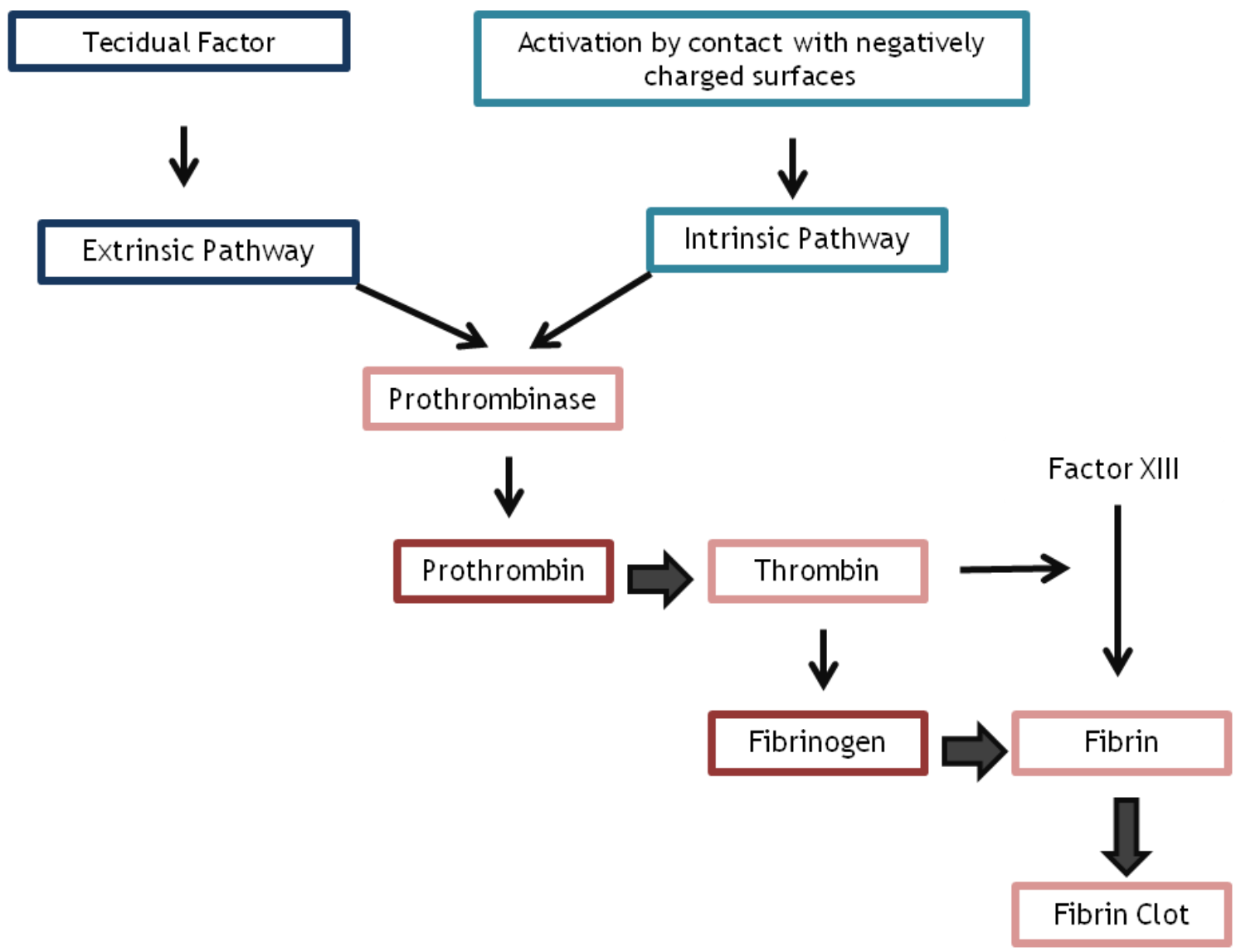

Figure 5- Pathways of activation of coagulation cascade (based on [18]).

When a vascular vessel suffers a small rupture, platelets may accumulate at the site to block the hemorrhage and maintain the integrity of the circulatory system. This process involves several steps and starts with the adhesion of platelets to the collagen exposed by the injured vase. This interaction is mediated by the von Willebrand factor (VWF), a blood glycoprotein that acts like a bridge between platelets and collagen promoting its binding. After binding to collagen, platelets are activated and release compounds like thromboxane that stimulate other platelets to become active as well. This way, their surface receptors bind to fibrinogen that promotes platelet-platelet binding and, consequently, the formation of platelet agglomerates (Figure 8) [69], [70]. 


\subsubsection{Fibrinolytic System}

Without a control mechanism, coagulation would spread throughout the organism leading to acute incidents. To prevent that, natural anticoagulants present in the blood act to suppress the coagulation factor activity and hinder blood clots continuous formation. Some of those anticoagulants are anti-thrombin, heparin and prostaciclins [71] [72].

The fibrinolytic system, represented in Figure 6, is responsible for blood clot degradation also contributing for coagulation control. In this process, thrombin, factor XII, tecidular plasminogen activator and other enzymes activate the plasminogen present in the blood which converts into plasmin, an enzyme that hydrolyzes fibrin. By the action of plasmin, fibrin molecules are fractionated releasing small pieces of clot to be phagocyted or removed by blood [73].

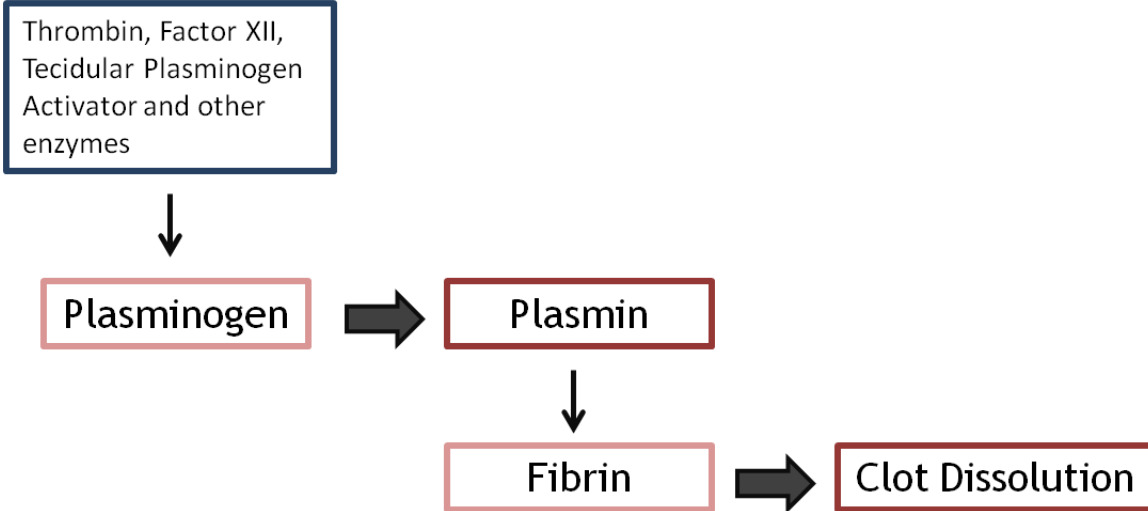

Figure 6- Fibrinolytic System (based on [18]).

\subsubsection{Complement System}

The complement plays an important role as a defense mechanism of the human organism, by participating in the inflammatory response and by being part of the innate immune system. It is composed of several plasmatic and membrane proteins synthesized mostly by the liver, monocytes, macrophages and fibroblasts. Those proteins are responsible for many biological events associated with the immune response, opsonization, chemotaxis and cellular lysis, for instance. As may be seen in Figure 7, the complement is divided in 9 components (C1-C9), with major (b) and minor (a) fragments and can be activated in three different ways: lectine pathway, classic pathway and alternative pathway.

The alternative pathway starts with the adsorption of $\mathrm{C} 3$ proteins on foreign surfaces, as bacterial components and biomaterial surfaces. This is the most common pathway applied to biomaterial surfaces. However, the classical pathway can also be activated by biomaterials through factor XIla fragments that are able to activate component C1.

All pathways lead to the formation of membrane attack complexes that start with a C5b component and end with the addition of $\mathrm{C} 9$, resulting in a canal constituted by polymerized C9 molecules that allow the passage of water and electrolytes through the cell membrane and lead to osmotic lyses [74]. 
To summarize, complement system activation results in cell lysis when the membrane attack complex is inserted in cell membrane.

Complement activation also releases several components as C3a, C4a and C5a involved in the inflammatory processes by increasing vascular permeability and activating leukocytes. C3b component may also induce the adhesion of leukocytes when bound to foreign surfaces [75].

Coagulation system and complement system interact between them modulating each other's activity. This interaction depends of some coagulation system' proteins that act on complement system provoking a response or vice-versa. For example, thrombin can activate fragments C3, C5 and C6 [65].

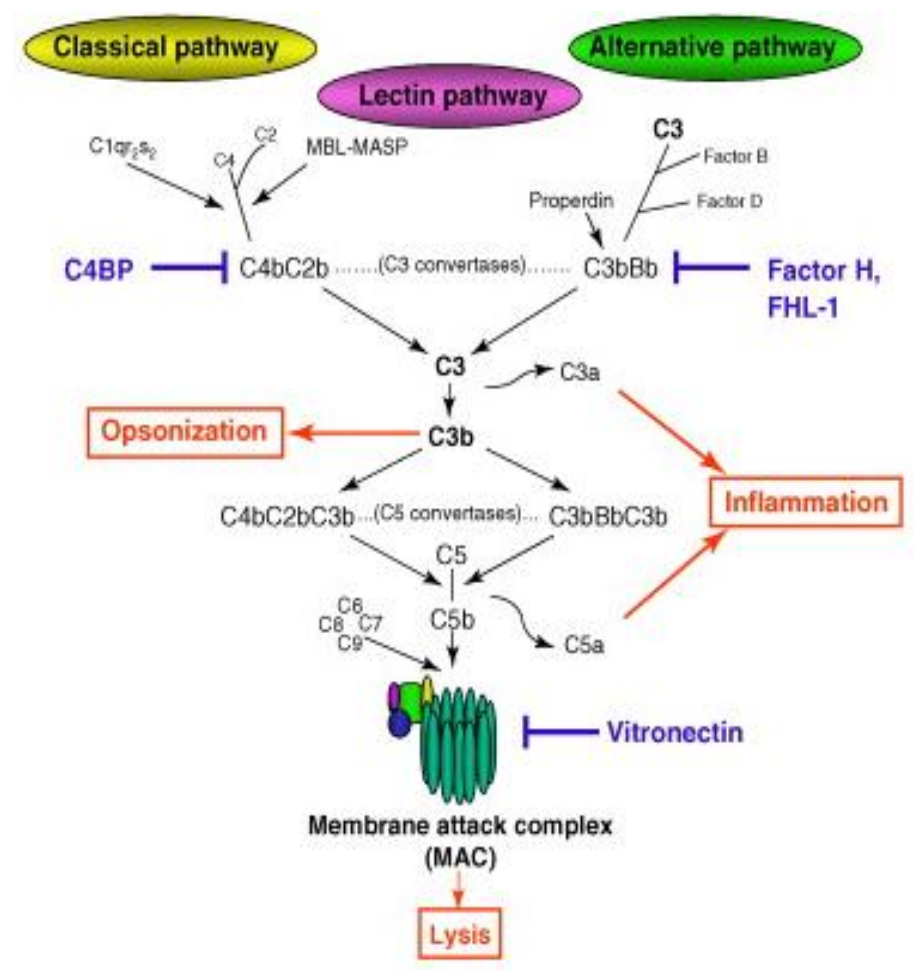

Figure 7- Different pathways of complement system [76].

\subsubsection{Interaction of Blood Cells with Biomaterials}

Plasma proteins adsorption on biomaterials is a complex process that may involve the coagulation and complement systems. Platelets and leukocytes are the main cells interfering with the blood cells interaction with the biomaterials [5].

\subsubsection{Platelets Adhesion and Activation}

Platelets are annucleate cells present in human blood in a concentration of $2.5 \times 10^{5}$ platelets $/ \mu \mathrm{L}$. They are small in size $(3 \mu \mathrm{m})$ and exhibit a disc-like shape when inactive. These cells are formed in the red bone marrow by megakaryocyte cells that, from time to time, break and release pieces of membranes that eventually will become platelets [77]. 
Platelets are responsible for blood clotting and the formation of scars. At their surface, platelets have glycoproteins acting like receptors that recognize other platelets and molecules and allow the formation of platelet aggregates [78]. Fibrinogen is one of the most important molecules which platelets can bind to since it allows platelets to aggregate with each other. Fibrinogen has two RGD (Arg-Gly-Asp) sequences in the subunit Aa and a dodecapeptide (sequence HILGGAKQAGDV) in the carboxyl terminus (or C-terminal) of the subunit $\gamma$ that are involved in the binding to the integrin GP IIb/IIla in platelets [79]. When fibrinogen adsorbs to a surface it acquires a different conformation by exposing the dodecapeptide in the $\gamma$ chain. This way, platelets can bind to surface adsorbed fibrinogen (Figure 8). Thus, conformation of adsorbed fibrinogen will mediate platelet adhesion to biomaterials being conformation more important than the amount of adsorbed fibrinogen [51]. Inactive platelets, however, cannot bind to soluble fibrinogen in the bloodstream unless they are exposed to thrombin, collagen or other agonist; only then, integrin GP IIb/IIla becomes an effective receptor to bind to fibrinogen.

Active platelets have different shapes according to the level of activity expressed. Depending on that, they can be classified in round, dendritic, spread dendritic, spread, and fully spread, with round representing inactive or less active platelets and fully spread representing the maximum state of platelet activity (a figure with platelets states of activation can be consulted in Figure 30, section 4.4). The activation and adhesion of platelets to biomaterial surfaces is highly mediated by fibrinogen; yet, other proteins, like fibronectin and vitronectin, can be involved in hemostasis as well [80].

Activated platelets secret polyphosphates that activates factor XII, initiating fibrin production by intrinsic pathway of coagulation, leading to thrombus formation [81]. This way, to avoid platelets activation is so or even more important than prevent platelets adhesion. Also, recent studies have shown that platelets can interact with bacteria, promoting its adhesion, so if a surface leads to platelet adhesion it can also consequently lead to bacterial adhesion, with infection scenario [82]. 


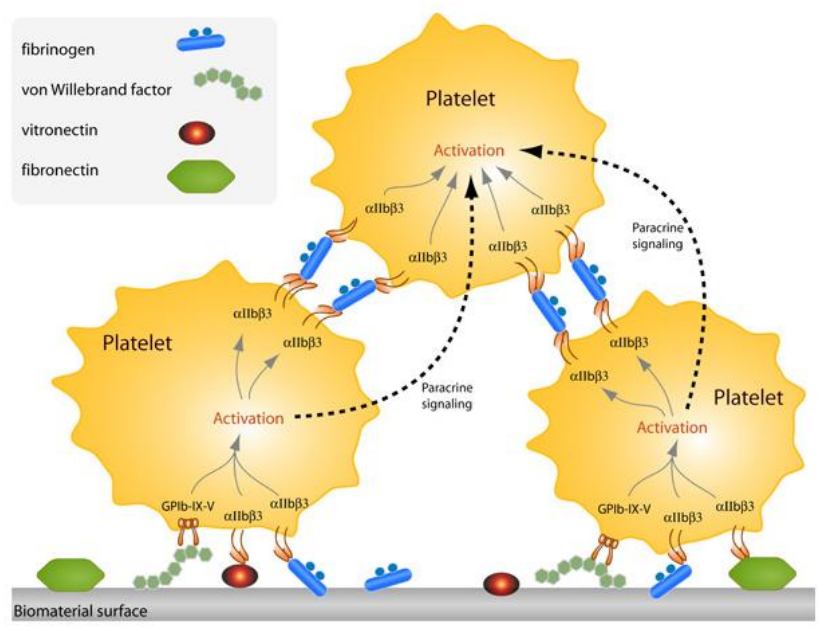

Figure 8- Platelet adhesion, activation and aggregation processes [83].

\subsubsection{Leukocytes Adhesion and Activation}

Leukocytes are white blood cells present in peripheral blood and extremely important to the immune system. Depending on their functions leukocytes can be divided in monocytes, neutrophiles, eosinophiles and basophiles, all responsible for ingesting and eliminating external particles. Lymphocytes are another type of leukocytes and display a more specific response against foreign antigens [74].

Since leukocytes integrate the immune system, when a biomaterial is implanted an inflammatory response is triggered to defend the organism against the foreign body. In fact, this inflammatory process can be so aggressive that biomaterials are destroyed by the leukocytes [84].

Adhesion of leukocytes to biomaterial surfaces depends on various surface properties such as wettability, composition and charge. Some other factors as protein adsorption, platelets and bacteria adhesion and complement activation also influence leukocyte adhesion. Leukocytes can recognize proteins adsorbed onto a surface and bind. Indeed, when proteins adsorb to a biomaterial surface they expose ligands recognized by the leukocyte receptors. One of the proteins affecting leukocyte inflammatory response is fibrinogen. Fibrinogen acts by increasing leukocyte recruitment and adhesion to implanted biomaterial [85]. Adhesion of leukocytes to biomaterials can lead to other problems aside from inflammation: formation and detachment of microthrombus through platelet-leukocyte interactions, release of leukocyte products that can cause systemic vascular reactions and leukocyte spreading through the organism, are some of the many [86]. 


\subsection{Catheter-Related Infections}

Bacterial adhesion is a very serious threat to the patient's health during implantation. Application of catheters or other implants, for instance shunts, stents or heart valves, is a common and efficient procedure in the medical field; however, the danger of infections raises the need for fast and durable solutions [87].

The protein layer that surrounds a biomaterial after implantation works as ligands to cell and bacteria membrane receptors, which compete with each other for the surface of the biomedical device [55]. When bacteria adhere to a material's surface a series of reactions take place and induce the formation of a biofilm which consequently lead to infections. From these infections a variety of problems can arise including implant removal, prolonged hospitalization or even dead. Intravascular catheters are a leading source of infections in cardiovascular systems, especially among critically ill patients and cancer patients [88]. Despite all hygienic care strategies implemented in the last years to reduce infection incidence, mortality is still very high. More than 250,000 vascular catheter-related infections occur annually in the USA with a mortality ranging from $12 \%$ to $25 \%$ [37]. A study from Spain revealed a mortality rate of $22.4 \%$ in intensive care patients that developed catheter-related infections [89].

There are two different types of catheter-related infections: local and systemic. Local catheter infections are exit site infections and look like a tunnel. These affect only the surrounding zone of catheter insertion and are very often characterized by erythema, warmth, pain, induration, etc. Systemic catheter infections affect the whole body and can spread by transport of microorganisms in the bloodstream. Lately, systemic infections have been indicated as the cause of septicemia, a severe general infection, characterized by symptoms as fever, chills and hypotension stimulated in the presence of bacteraemia or fungaemia [90]. In this work we focus in Staphylococcus since these are the most frequently species found in infected intravascular catheters (Figure 9).

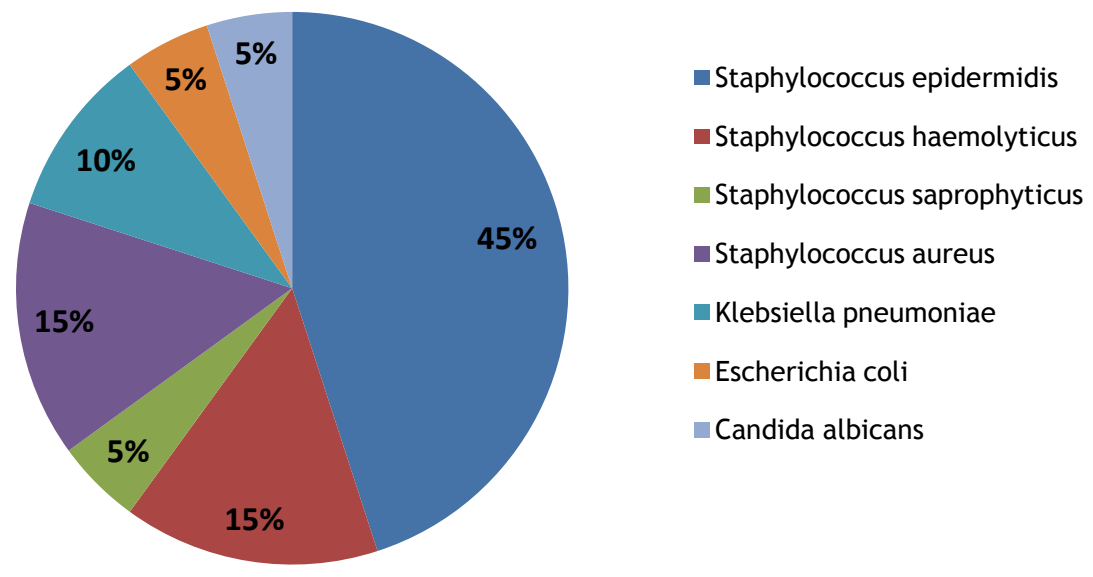

Figure 9- Incidence of microorganisms in central venous catheter-related infections (based on [91]). 


\subsubsection{Bacterial Adhesion and Biofilm Formation}

The difficulty to eliminate microorganisms responsible for intravascular catheter-related infections is many times correlated with the capacity of the microorganisms to form biofilms [92].

Bacteria have the capacity to specific adhere to the surface of a biomaterial mostly because of the proteins that adsorbs on the material, once it is implanted. Binding between bacteria and surface is mediated by adhesins, bacteria appendices (fimbriae) that promote adhesion to other cells or surfaces by binding to specific receptors.

Biofilm formation is divided in three main phases, initial phase, second phase and final phase (Figure 10). Initial phase is physically reversible and is characterized by physicochemical interactions between bacteria and surface [93]. It starts with transport of bacteria to the surface via diffusion, convection and/or bacteria active movement. When in the surface, bacteria adhere reversibly by means of electrostatic, ionic or van der Walls interactions. This binding, however, can be broken by the action of shear forces or bacteria active movement [94].

Bacterial adherence is affected by different factors as bacteria strain, biomaterial surface properties, and environmental factors. The last two are perhaps the most influent factors and those we can better alter or control to generate new and improved medical devices for patient care. Factors as surface hydrophilicity or roughness can influence bacterial adhesion. Rough surfaces, because of the presence of furrows, stimulate bacterial adhesion compared to smooth surfaces. Environmental factors as temperature, antibiotics presence, exposure time, bacteria concentration, and the presence of certain proteins can be as well crucial [95][96].

The second phase is irreversible, time dependent and characterized by cellular and molecular interactions. In this phase, a set of specific interactions happen between bacteria adhesins, as fimbriae, pili or capsules, and specific surface structures, culminating in a irreversible fixation. In the end of the second phase, colonization takes place. Here, bacteria bind to the surface and start to replicate in new bacteria forming clusters capable of originating biofilms.

Final phase, or phase 3 correspond to biofilm formation and maturation. A biofilm is generated when microorganisms adhere to a surface, tissue or inanimate material, replicate and secrete insoluble gelatinous exopolymers. Through these, they form a three-dimensional and well organized matrix composed of polysaccharides, proteins, nucleic acids and lipids, which are produced by them or by the surrounding cells. The resultant matrix layer, named slime, hinders antibiotics access to local infection and phagocytosis by immune cells. This slime is highly resistant even in non ideal environmental conditions: alterations of $\mathrm{pH}$, osmotic shock, UV radiation, flow conditions, and most importantly antibiotic and biocidal substances, making bacteria more resistant when organized in biofilms [97]. 


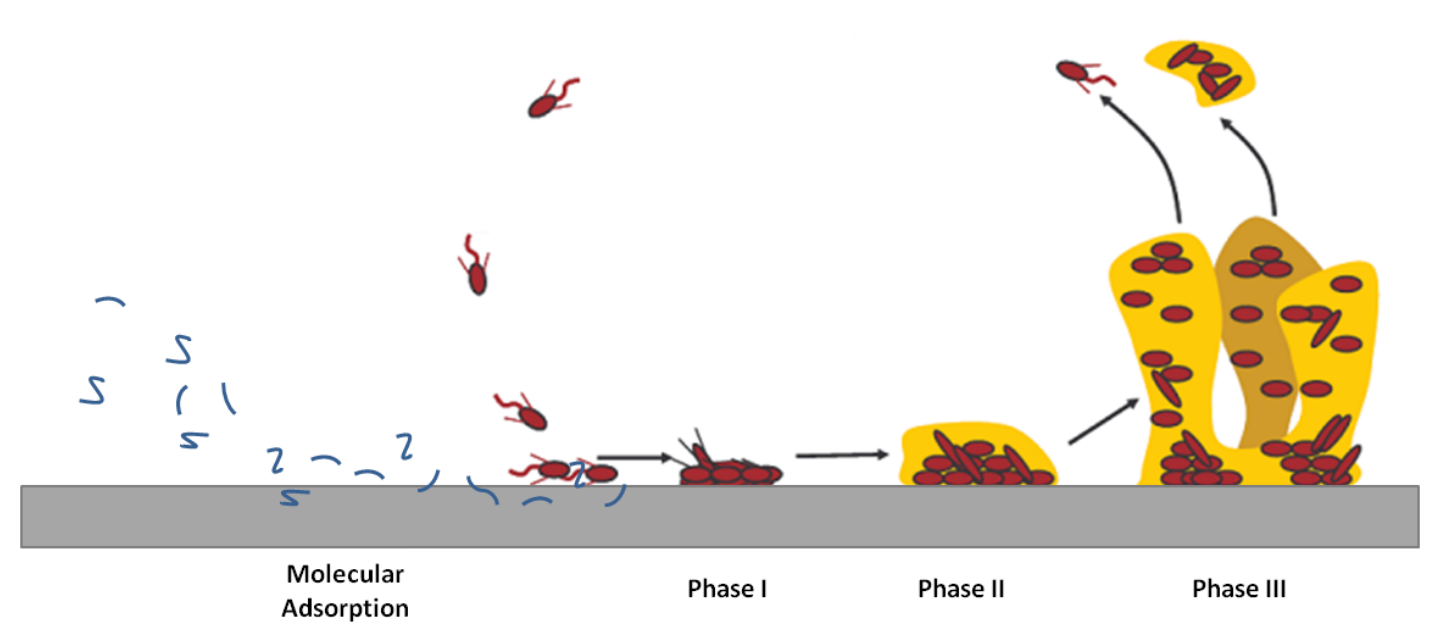

Figure 10- Different phases of biofilm formation and maturation (adapted from [100]).

Moreover, microorganisms growing in biofilms are less susceptible to antibiotics and host defenses, because when organized in biofilms, bacteria remain in latency and most of antibiotics are only effective against metabolically active bacteria. Also some biofilms are constituted by a diverse community of bacteria and antibiotics are effective specific against specific bacteria. These are the main factors that increase bacteria resistance. In fact, studies have shown that sub-lethal doses of antibiotics can actually enhance biofilm formation [98]. Nosocomial infections are one of the main causes of biofilms formation since they can develop and grow in medical devices or equipments [99]. Often, biofilms lead to material deterioration or accelerate their corrosion, products contamination, decrease in frictional fluid resistance, etc., which may destroy specific medical devices with consequences to the patients. Also, they can provoke very harmful and serious responses from the patient's organism as complement activation, cytokines release and free radicals production. Biofilms are very dangerous to the organism, since they not only are a source of infection but can also induce thromboembolisms by releasing from the surface [45].

\subsubsection{Staphylococcus}

Staphylococcus is a group of bacteria that belongs to the Micrococcaceae family. The name Staphylococcus comes from the Greek and relates to the cocci arrangement of these microorganisms. Under microscope observation, these bacteria look like a bunch of little round berries, all close together with a purple coloration since they are Gram-positive.

The main difference between Gram positive and Gram negative bacteria is related to its cell wall (Figure 11). The Gram stain method uses crystal violet dye and allows differentiating bacteria in Gram positive and Gram negative according to cell walls characteristics [101]. Gram positive bacteria have a layer rich in peptidoglycans with low lipid and lipoprotein content, becoming more resistant, less susceptible to dissolution. The high content in peptidoglycans and magnesium on its wall is what permits to retain crystal violet dye.

On the other hand, Gram negative bacteria have a thin peptidoglycan layer and are rich in lipids and lipoproteins due to existence of an extra outer membrane. This type do no retain crystal violet due to the absence of magnesium and few peptidoglycans on its wall, so bacteria become colored by red or pink [102][103]. 


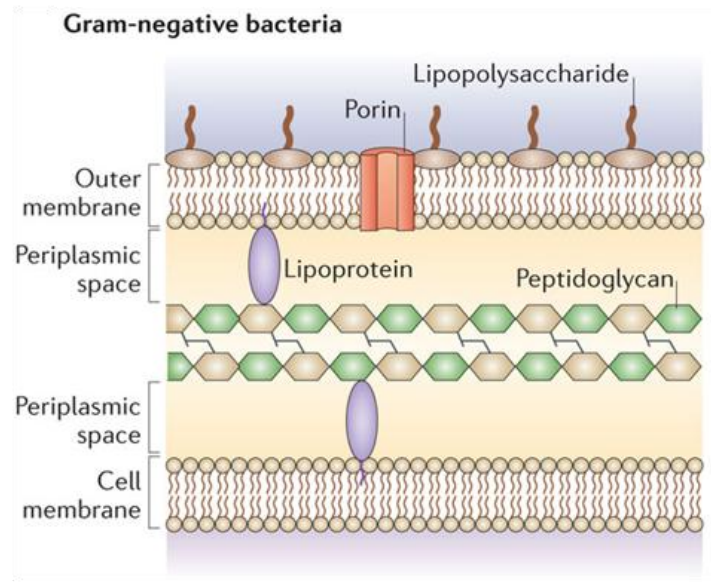

(A)

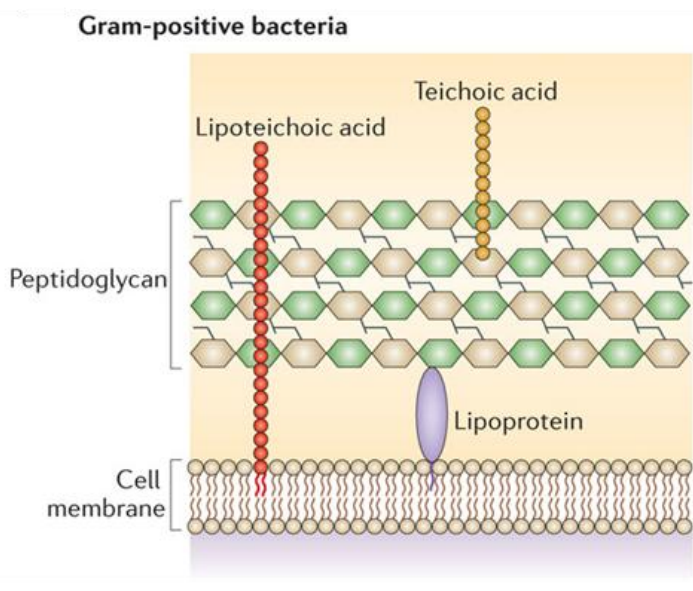

(B)

Figure 11- Cell wall of Gram negative (A) and Gram positive bacteria (B).

Aside from being Gram-positive, staphylococcus are facultative anaerobic and are usually encapsulated. This capsule is formed by a polysaccharide layer and protects Staphylococcus against immunological defenses, such as leukocytes and phagocytes. It also can facilitate bacteria adhesion to biomaterials as joints, prosthetic valves and catheters. The diameter of Staphylococcus varies between 0.5-1.5 $\mu \mathrm{m}$. These bacteria are non-motile (incapable of movement) and catalase positive.

There are a total of twenty seven species of Staphylococcus but only fourteen species and two subspecies can be found in humans. They usually grow in the skin and mucous membranes. The species most associated with infection cases in humans are the S. aureus, $S$. epidermidis, S. haemolyticus, S. lugdunensis, S. saprophyticus and S. schleiferi. All of these species are coagulase negative except for $S$. aureus that is coagulase positive, meaning that it has the ability to produce the enzyme coagulase.

Staphylococcus are microorganisms that easily gain resistance to antimicrobials and are then capable of transmitting that same resistance to other bacteria. For instance, the resistance of Staphylococcus to penicillin is mediated by the production of B-lactamase that hydrolyzes the B-lactam ring of penicillin.

Portugal, in 2008, was the only European country whose methiciline-resistant S. aureus prevalence in hospitals was over $50 \%$ [104].

In order to solve this problem, semi-synthetic penicillins resistant to B-lactamase hydrolysis were developed; still, bacteria became resistant to this sort of antibiotics by altering the antibiotic target sites (penicillin-binding proteins). To treat efficiently these infections antibiograms are conducted to understand which drug is more efficient against a specific bacteria [105].

Because of the variety of Staphylococcus species that can affect humans, a wide number of diseases have their origin in these microorganisms [106].

Catheter contamination by Staphylococcus is frequently a cause of bacteremia since microorganisms have continuous access to the bloodstream, this way spreading infections throughout the entire organism [107]. For the purpose of this research we will focus our attention on S. epidermidis bacteria, one of the most frequent bacteria to cause catheter infections [1]. 


\subsubsection{S. epidermidis}

S. epidermidis (Figure 12) is the most frequently specie of staphylococcus to be isolated from human epithelia. It colonizes human skin and mucosa surfaces and as all the other staphylococcus species is gram-positive. This specie, in particular belongs to the coagulasenegative group of staphylococcus, since it lacks the enzyme coagulase [108][109].

This microorganism can cause nosocomial infections very easily because of its presence in the skin and mucosa, which facilitates its entrance in the body via injuries or implanted medical devices [110]. S. epidermidis has the ability to form biofilms on or within the medical devices, whose elimination and treatment are very complicated. This specie can relate well with catheters in the matter of infections since it has the capacity to produce slimes, that prevents bacteria from phagocyte ingestion [111] .

S. epidermidis now accounts for at least $22 \%$ of bloodstream infections in intensive care unit patients in the USA, which occur in at least 4-5/1000 central venous catheter insertions [112]. This is one of the main reasons why this staphylococcus specie was chosen to be use in this research.

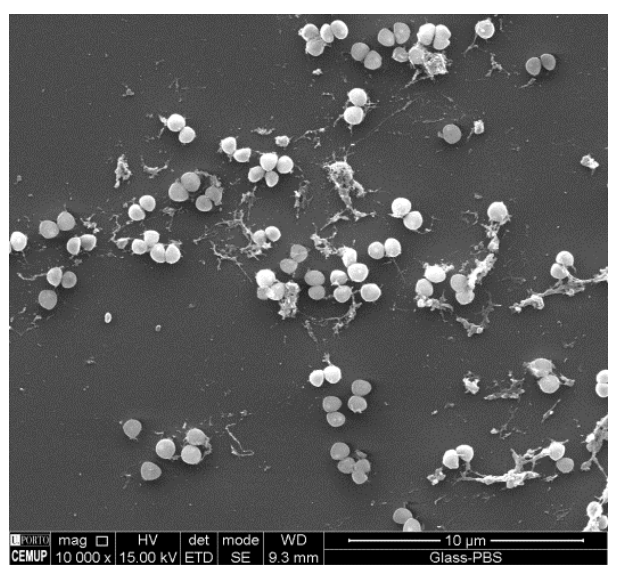

Figure 12- Staphylococcus epidermidis. Original scanning electron microscopy (SEM) image at magnification 10,000x.

\subsubsection{Strategies to Prevent and Treat Catheter-Related Infections}

All the problems associated with bacterial adhesion to biomaterials, and consequent biofilm formation, has increased the scientific research to find new and better strategies to avoid and treat infections.

The development of biomaterials with anti-infective properties is one of the most studied strategies to prevent infections associated with medical devices. Among these anti-infection biomaterials we can find materials with:

i) antifouling properties and with

ii) bactericidal activity,

- killing by contact or

- delivering antibacterial compounds [17][14] 


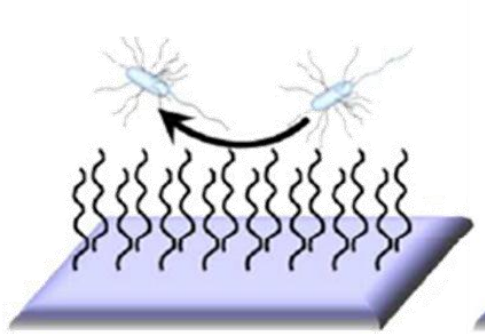

Anti-adhesive Surface

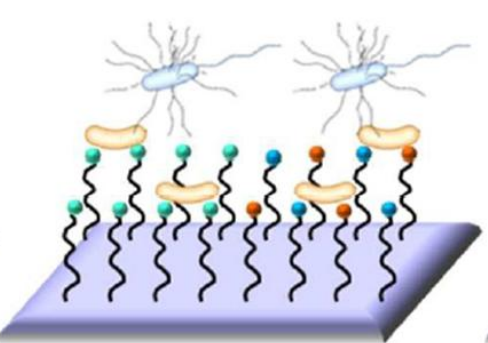

Contact killing Surface

(A)

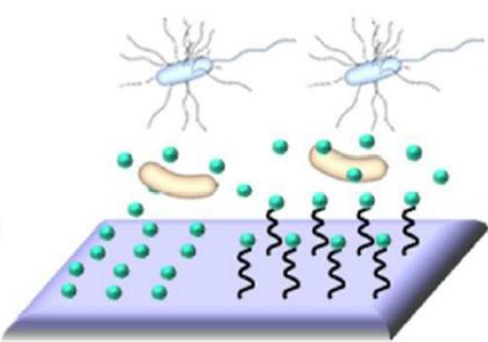

Biocide releasing Surface

(C)

Figure 13- Surfaces with bactericidal effect by direct contact (B) and by release from the surface (C).

(A) Surface with non-fouling properties. Adapted from [113].

\section{i) Biomaterials with antiadhesive properties}

There are several ways to produce biomaterials with anti-adhesive properties acting at level of surface modification.

Surfaces with high negative charge, polyanionic surfaces, have the ability to repulse bacteria with polianionic glycocalice (most of gram-positive bacteria) through electrostatic interactions, however, gram-negative bacteria have policationic glycocalices, so this surface modification mechanism is only effective against a specific number of bacteria [7] .

Also coating with polymeric brushes can prevent bacterial adhesion, by avoid bacteria to directly contact with the surface. Usually, antifouling surfaces, such as the ones with polymer brushes (Figure $13 \mathrm{~A}$ ), are hydrophilic, however, they can also be superhydrophobic. Superhydrophobic surfaces act through a wetting mechanism that prevents the contact between bacteria and attachment points on the material [114]. Also zwitterionic surfaces can have anti-fouling properties avoiding proteins adsorption and consequent bacterial adhesion [115],[116].

Protein adsorption on biomaterial is an initial step to bacterial adhesion, so the biomaterial's surface can be modified to avoid such so. This process can be achieved by reducing the protein-surface interaction or by decreasing the rate of protein adsorption on the surface. Also the surfaces can be previously adsorbed with selected molecules that can modify surface hydrophobicity or hydrophilicity as albumin that prevents bacterial adhesion, as explained in section 2.2.2 [117].

\section{ii) Biomaterials with bactericidal activity}

There are several materials with intrinsic antibacterial properties, as silver, zinc, cooper, or chitosan. Nevertheless, materials can also be modified to acquire bactericidal activity [17]. Antibacterial coatings are an example, chemical or physical changes on the surface can produce bactericidal effect, however, is important to maintain a balance between antibacterial properties and biocompatibility of the coating, since it will be in contact with host's tissues or blood [7].

- Killing by contact

Antibacterial coatings can fixate certain antibacterial molecules on the material surface or can release those molecules. Several coatings can be classified as "contact biocides" since 
they use some substances (e.g. antimicrobial peptides) that kill by contacting with the bacteria with no need to release from the surface [118] [119].

- Delivering antibacterial compounds

However, there are coatings that release substances (e.g. nitric oxide) with antibacterial properties that will interact with bacteria in a larger distance from the bulk. It is important, though, that this release into the surrounding tissues be controlled to avoid toxic effects [120]. In (Figure $13 \mathrm{~B}$ and $\mathrm{C}$ ) is possible to see a contact killing surface and a biocidal releasing surface.

About catheter-related infections there are several strategies to prevent and treat them, however, they are not very effective. Infections caused by catheters are often treated with antibiotics. However, this has become quite a challenge because of the increased resistance of bacteria to antibiotics. Yet, the most frequent form of treatment of catheter-related infections continues to require the device removal or substitution [106].

In some hospitals heparin is administrated to patients using central venous catheters to prevent deep vein thrombosis and pulmonary embolism. However, as explained before, it can be dangerous to some patients. To avoid these situations, several strategies have been proposed to prevent catheter-related infections: cutaneous antisepsis using povidone-iodine for local catheter insertion, maximum sterile barrier precautions as wearing sterile gloves, cap and gown and more recently the use of antimicrobial coated catheters [38].

Antimicrobial coated catheters are catheters on which an antimicrobial agent has been coated to its surface to prevent or minimize adherence of microbial organisms. There are various types of antimicrobial catheters that can be applied according to each situation. Antiseptic catheters, for instance, are central venous catheters made of PU and coated with chlorhexidine and sulfadiazine silver. Another type, silver-impregnated catheters use a mechanism in which silver, platinum and carbon are incorporated in the catheter allowing topical silver ion release [96]. Antibiotic-coated catheters with minocycline and rifampicin are perhaps the most frequently used; still, they present a major limitation since bacterial resistance to the antibiotics increases in long-term applications [121].

To overcome this problem several studies have been made to find viable alternatives to antibiotics. Catheters coated with antimicrobial peptides (AMPs) could be a promising strategy [36].

\subsection{Antimicrobial Peptides (AMPs)}

Antimicrobial peptides (AMPs) are a class of peptides with a broad activity against bacteria, virus and fungus. These peptides provide a non-specific defense against a broad spectrum of invaders of their host, acting like a component of innate immune system. These peptides are produced by various animal and plants [122]. However, they can also be produced synthetically, so is possible to divide AMPs in natural and synthetic.

AMPs are small peptides (with five to one hundred amino acids). They are often cationic molecules due to the excess of lysine, arginin and histidine, although, recent studies have proved the existence of anionic, negatively charged AMPs [123].

Most AMPs are amphipathic, meaning that they have both hydrophilic and hydrophobic faces. Amphipathicity affects mostly the binding to microbial surfaces, since it is necessary a strong partition into the membrane interface [124]. Amphipatic a-helix structure is one of the 
most effective interacting with biomembranes, easily permeabilizing microbials. This way, amphipathic helicity influences peptide activity. Solubility and some mediators as proteases, metals, salts or even chemical modifications can also regulate peptide activity [125].

There are several types of AMPs but it is possible to group them in four main classes, according to its structural diversity: a-helix, B-sheet, extended and loop (Figure 14). The most common types are a-helix and B-sheet, the first is formed only when the peptide contacts with a membrane, and the second is stabilized by 2-4 disulfide bonds. The less common, extended and loop, display a curved form in response to a simple disulfide bond or the presence of proline residues in its structure [126], [127].

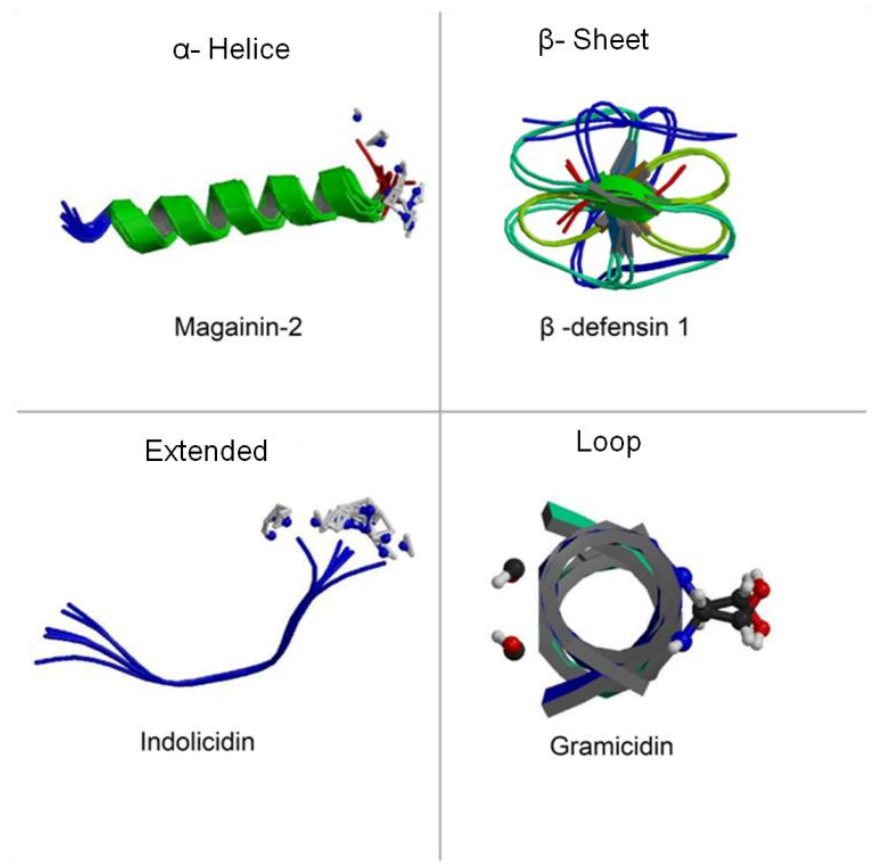

Figure 14- Possible structures of AMPs. Adapted from [131].

AMPs are frequently found in plants and animals but can also be produced by prokaryotes as bacteria, and by fungi, protozoan and insects. Over than 5000 AMPs have been discovered or synthesized. Natural AMPs are those found in nature, produced by organisms. Synthetic AMPs are produced artificially through chemical synthesis or recombinant expression. Since they are composed of amino acids it is relatively easy to immobilize and modify their structure, being possible to obtain new AMPs with improved stability and greater range of targets [128].

There are several eukaryotic cells capable of producing AMPs, like epithelial cells from gastrointestinal and genitourinary systems, phagocytes and lymphocytes. In animals, AMPs are part of the innate immunity generated by the immune system. They can be found mostly on the tissues exposed to airborne pathogens. In plants they form a system of defense, similar to the innate immunity in animals, that protects the organism from pathogens and plague attacks [129]. Humans also have some AMPs in their organism, as a-defensin 6, B-defensin 120 , chemokine CCL24, chemokine CCL26 and human ribonuclease 6 . These peptides or proteins are effective against several pathogens (i.e. bacteria). Upon invasion, AMPs production can be stimulated; for example, cathelicidin, a human antimicrobial peptide, is produced by skin fat cells after S.aureus infection [130]. 


\subsubsection{Mechanisms of Action}

In contrast with the mechanisms of action of classic antibiotics, which are based in slow processes of enzymatic inhibition and target specific cellular activities as DNA or protein synthesis, AMPs target the lipopolysaccharide layer on the cells membrane which is similar to all microorganisms. AMPs are very quick during killing process; they can kill microorganisms in seconds after contact with the cell membrane. They may also display synergistic effects with antibiotics by increasing antibiotic activity above the antibiotic individual effect [132].

AMPs can be classified in four main types according to the target microorganism: antiviral peptides, antifungal peptides, antiparasitic peptides and antibacterial peptides.

Antiviral peptides can kill viruses by integrating the host cell membrane or viral envelopes and causing membrane instability. This membrane instability makes viruses incapable of infecting host cells. AMPs can also act by blocking viral receptors, by preventing viruses to bind to viral receptors on the cell membrane already occupied with AMPs [133].

Antifungal peptides can neutralize fungi by targeting and binding to intracellular components or the cell wall, as chitin for example, disrupting the integrity of the fungal membrane, and forming pores or increasing permeabilization of the plasma membrane [134].

Antiparasitic peptides are a smaller group which comprises AMPs as magainin and cathelicidin. They kill parasites by directly interacting with the cell membrane and forming pores, like the previous categories of AMPs, even though some parasitic microorganisms are multicellular [135].

Antibacterial peptides are the most studied group of AMPs. Most of them are cationic or amphipathic, and target the bacteria cell membrane causing disruption. Those with hydrophilic and hydrophobic domains can bind both to lipid components and phospholipid groups. Most AMPs that interact with the bacteria surface cause disturbs in the structure of the lipid bilayer and may lead to the cell lyses [136]. Those AMPs positively charged are attracted to the anionic surface of the bacteria membranes causing electrostatic interactions that on its turn may lead to membrane disruption [137].

Initially the peptides cover the bacteria membrane and change their orientation from parallel to perpendicular to the membrane surface. Next, they form pores on the membrane eventually leading to its disruption. Three models (Figure 15) explain the mechanism of action of membrane-active AMPs:

(1) The carpet model: there is formation of an extensive hole in lipid layer that bends back on itself causing lysis of the cell.

(2) The toroidal pore model: peptides insert into the membrane and form clusters that in association with water molecules create channels that allow leakage of ions and molecules to the outside and peptide entrance to the inside, exerting their killing activities.

(3) The barrel-stave model: peptides interact laterally with each others to form specific barrel-like structures that line amphipathic transmembranes pores, hydrophobic tails at the inside of the phospholipid bilayer and the hydrophilic side-chains oriented inward into the water-filled pore [138][139]. 

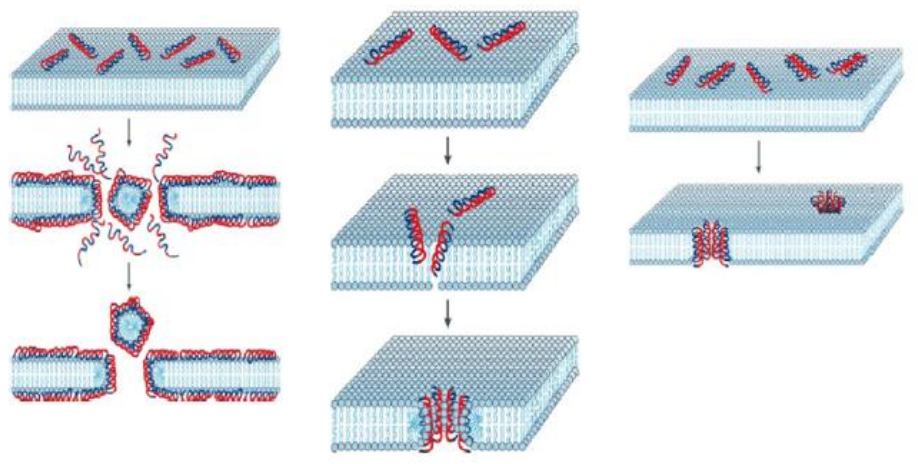

Figure 15- Mechanisms of action of membrane-active AMPs: carpet, toroidal pore and barrel-stave model [138].

Studies have shown that AMPs can kill bacteria not only by disrupting its membrane but also by inhibiting some important pathways inside the cells, such as DNA replication and protein synthesis, and by interacting with some intracellular components [140], [141].

AMPs also have the ability to inhibit some functional proteins on the cell membrane, increasing the velocity and efficacy of AMPs activity in killing microorganisms. Indeed, because those proteins have several main functions as nutrients transportation, respiration, intercellular communication, etc., this protein inhibition associated with membrane disruption accelerates the AMPs' killing effect [142]. AMPs can also kill antibiotic resistant bacteria and some are even effective against more than one class of microorganisms[143]. Indolicidin, for instance, kills bacteria, fungi and viruses; such a broad spectrum of action is a great advantage over single target antibiotics [133].

\subsubsection{AMPs Immobilization}

AMPs are usually immobilized on solid surfaces chemically or physically. On the chemical methods we can find covalent immobilization and on physical methods the layer-by-layer assembly and physical adsorption [144]. Although, those are the most frequent types of AMPs immobilization there are some other strategies already tested as the incorporation in nanoparticles acting as delivery systems [145].

Physical methods are based on hydrogen bonds, dipole interactions (van der Waals' force or London dispersion force), and hydrophobic or ionic interactions between AMPs and surfaces. Simple physical adsorption is one of the easiest ways to immobilized peptides, however the antimicrobial effect at long term application may not be very effective [146]. Also incorporation techniques were tested in order to directly incorporate AMPs in the biomaterial as collagen matrix [147] or a calcium-phosphate bone cement [148].

Layer-by-layer is a physical immobilization method commonly used and in this case the AMPs are embedded between two polyionic polymers. The polymers not only hold the peptide on the inside but they also bind to the solid surface, forming a sandwich (polyanion-peptidepolycation) that can have several layers. This method can only be applied with highly charged and water soluble AMPs, a less frequent type. An advantage of this method is that it allows a high and controllable loading of the AMP on the surface. However, since the AMPs will not be in direct contact with the surrounding bulk there is a need for the peptides to release through 
diffusion. This diffusion through the membrane process could be complicated, besides, bacteria biding on the top layer of the sandwich may block the exit of AMPs from the inside of the matrix [123] [149].

In covalent immobilization, AMPs chemically react with a given surface to form stable and non-leaching antimicrobial coatings with increased time of duration [150]. Not all surfaces have the ability to directly react with AMPs, so it may be necessary some surface treatment to introduce the desired functional groups that will allow the grafting of the peptides. A process frequently used functionalized resins such as Poly(ethylene glycol) (PEG) or other polymeric 'brushes' that presents reactive groups suitable for AMPs covalent immobilization. Those PEG spacers, will allow rapid and free orientations of bound AMPs promoting peptidebacteria interactions, and enhancing the protective performance of the bound peptide layer on the surface [151]. However, there are some concerns as the possibility of polymer degradation reactions resulting in PEG chain cleavage and thus the release of bound AMPs.

Covalent immobilization has some advantages as an increased long-term stability and decreased toxicity. However, this immobilization method efficiency also depends on several factors such as chemical coupling strategy used, length and flexibility of the spacer, peptide surface concentration and peptide orientation [152].

The use of a spacer on covalent immobilization can be very advantageous. For example, PEG immobilization can give the surface non-fouling characteristics, forming a non-adhesive surface, avoiding bacterial adhesion. Actually, the utilization of a spacer could be a crucial step to obtain an efficient antimicrobial activity of the AMP. Studies have shown that some peptides are only effective when a PEG spacer was used [153][154].

Peptide concentration on the surface also affects its bactericidal activity; however there is some controversy about this subject. Although some studies defends that peptide concentration have less impact that spacer influence, for example, some other studies defend that a higher peptide concentration have more antibacterial activity, comparing to lower concentrations [155][149].

Also peptide orientation after immobilization on the surface may influence its antibacterial activity. Peptides can be immobilized by different chain positions, namely Cterminal and $\mathrm{N}$-terminal. The orientation of the peptide may determine the way it can interact with bacteria, namely with lipid bilayer during membrane pore formation [119][153].

During this work two different AMPs (CM and MSI-78) and two different strategies to immobilize them (surface covalent immobilization and bulk physical incorporation) will be explored.

\subsubsection{Cecropin-Melittin (CM)}

An hybrid of cecropin and melittin (Figure 16), is a combined AMP very efficient against gram-positive and gram-negative bacteria [156].

Cecropin peptides are composed of 35 to 39 amino acids in the form of two a-helix structures linked by a flexible segment and in a amphipathic form [157]. These peptides integrate a class of AMPs generated at the humoral immune system in insects (they can also be obtained from pigs). Cecropins have the ability to interact with membrane lipids to form channels with increased antimicrobial activity [158]. Also, they can inhibit protein importation and control or even inhibit mitochondrial respiration when in higher 
concentrations. These peptides have the advantage of not causing lyses in eukaryotic cells (non toxic) [159].

Melittin is a amphipatic AMP of 26 amino acids organized in a a-helix structure. It is commonly found in the venom of honey bee [160]. In spite of its antimicrobial activity, at high concentrations, this peptide causes lyses in red blood cells, being toxic to the organism. In addition, displays antiviral activity even at lower concentrations, being capable of disrupting viral membranes [161], [162].

Cecropin and melittin conjugation allow a more efficient defense mechanism to be formed. The segments of cecropin combined with melittin, increase antimicrobial activity, comparing to cecropin alone [163]. Also the association of this two AMPs decrease the hemolytic activity of melittin, becoming non toxic to the organism [164], [165]. Together, these two peptides are capable of exerting a broad antimicrobial activity against not only bacteria but also fungi, virus and protozoa [166], [167].

This hybrid chemical structure can be seen in Figure 14.

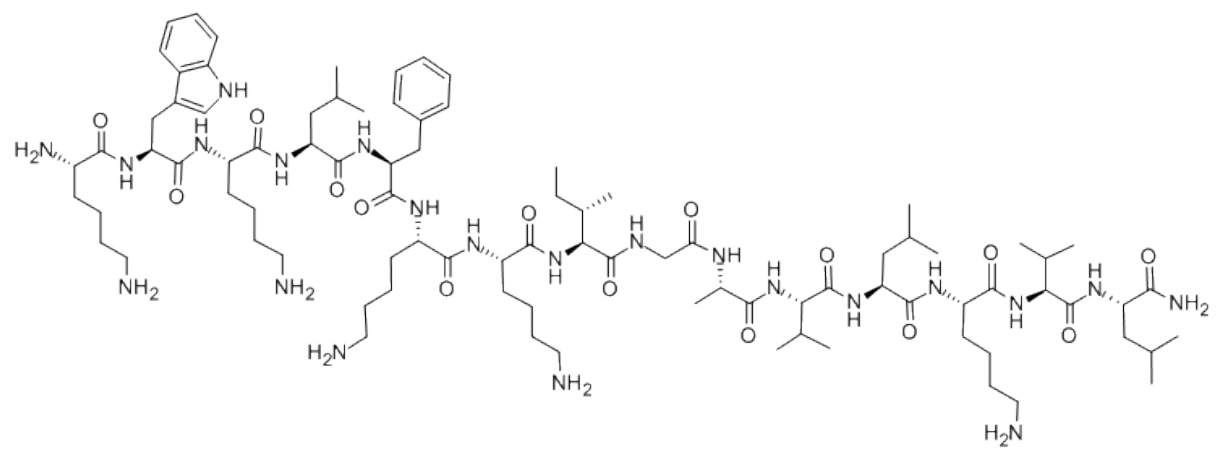

Figure 16- Chemical structure of CM [168].

\subsubsection{Pexiganan (MSI-78)}

MSI-78 is an AMP with 22 amino-acid sequence (GIGKFLKKAKKFGKAFVKILKK) (Figure 17) and an analog of the natural AMP, magainin 2, that can be isolated from the skin of Xenopus laevis, an African frog [169]. This synthetic peptide was developed to treat foot ulcers [170]

A great problem associated with magainin, is the loss of activity in animal models of infection, leading to the use of high doses of peptide that can become toxic to the organism. This way, new synthetic AMPs have been developed, with increased activity to overcome this problem [171] .

MSI-78 makes part of the a- helical group of AMPs and presents a broad spectrum of antibacterial activity against gram-positive and gram-negative bacteria. This antimicrobial activity is due to the ability of MSI-78 to disrupt bacterial membranes by forming toroidal pores (toroidal pore model) [172][173].

Studies were made, in order to improve MSI-78 activity or stability, by creating derivates of MSI-78 with similar structure but with different characteristics. In one of those studies, realized by our team, MSI-78 shorter derivates were designed to improve bacterial selectivity while maintaining antimicrobial activity and therefore, decrease the high cost of production associated with peptide synthesis [4]. 
In this work, two MSI-78 derivated AMPs were used, MSI-78 (1-17) and MSI-78 (2-18). Those AMPs presents 17 amino acids sequence, GIGKFLKKAKKFGKAFV for MSI-78 (1-17) and IGKFLKKAKKFGKAFVK for MSI-78 (2-18).
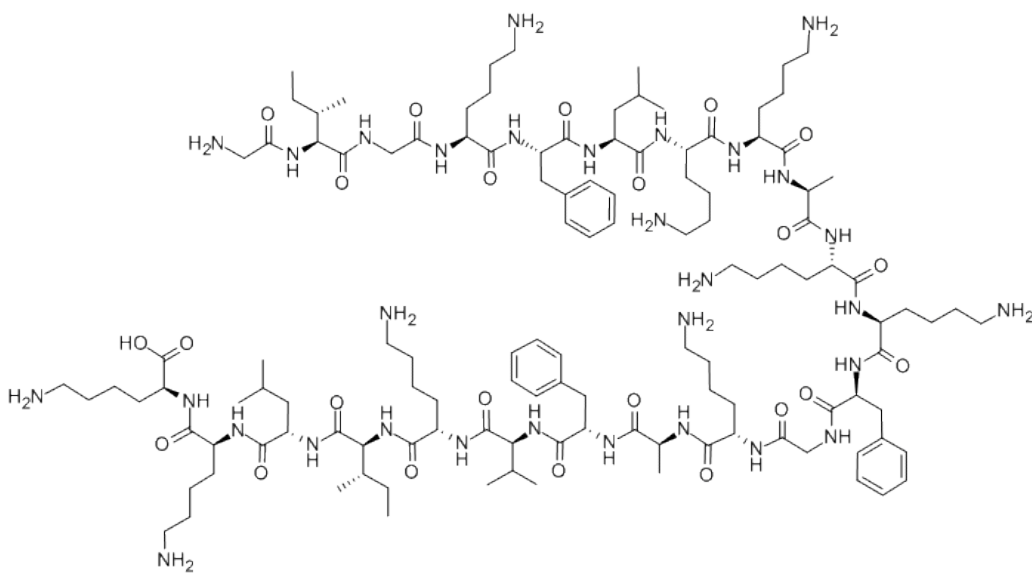

Figure 17- Chemical structure of Pexiganan [174]. 


\section{Chapter 3}

\section{Surface Characterization Techniques}

Several characterization techniques were used to analyze the surface of the materials studied in this work: PU, Au NPs and CM. The convergence of different characterization techniques allowed us to evaluate each surface from different angles: visual aspect, roughness, wettability and elemental composition.

\subsection{Scanning Electron Microscopy (SEM)}

SEM analyses the samples with a focused electron beam and deliver images with information about sample's topography and composition (Figure 18). This technique uses a high energy beam of electrons in a raster scan pattern that interacts with the atoms on the surface, under vacuum conditions. Those electrons carry high amounts of kinetic energy that is dissipated as a variety of signals produced by electron-sample interactions when the incident electrons are decelerated in the solid sample. These signals include secondary electrons, backscattered electrons, diffracted backscattered electrons, photons, visible light, and heat.

The signals that derive from electron-sample interactions are detected and contain information about the sample's morphology and topography, chemical composition and crystalline structure. Secondary electrons are most valuable for showing morphology and topography on samples, and that was the main information we wanted to obtain about our samples,

using

SEM

[175][14]. 


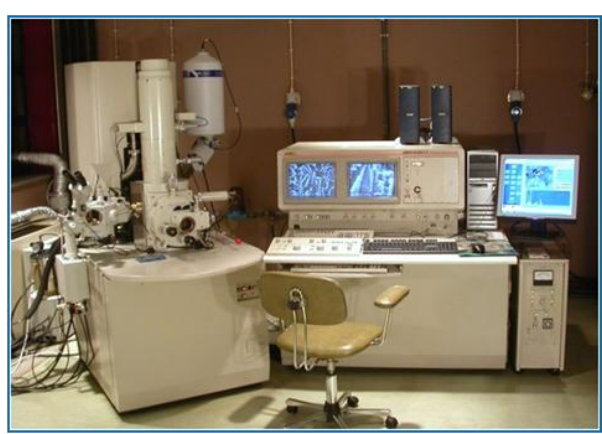

(A)

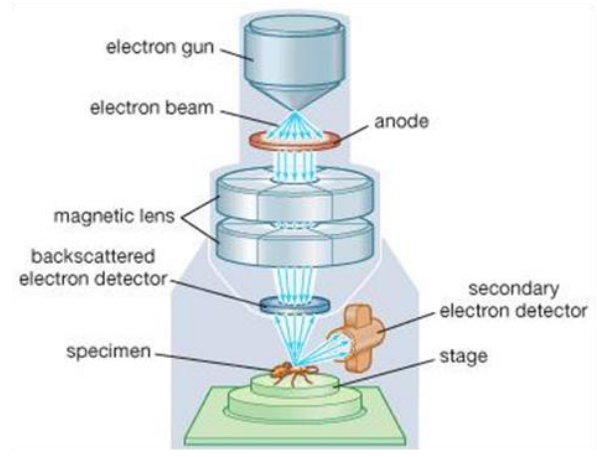

(B)

Figure 18- SEM equipment (A) and schematic representation of its components (B) (adapted from [176]).

\subsection{Contact Angle Measurements}

Contact angle measurements provide information about the surface wettability and its free energy. The contact angle is the angle, usually measured through the liquid, where a liquid-vapor interface encounters the solid surface (Figure 19). The contact angle measurement is based on the balance between the force of attraction of the liquid molecules to each other, and the attraction of the liquid molecules to the molecules of the surface. When a drop of liquid is placed on the surface, it spreads to reach equilibrium between cohesive (of attraction of the liquid molecules to each other) and adhesive (attraction of the liquid molecules to the molecules of the surface) forces with minimum energy.

There are several methods to determine a contact angle between a liquid and a surface, but one of the most common methods is the sessile drop (applied in this work). This is one of the most simple techniques in which a drop of a liquid (in this case water) is placed with a syringe on the surface and a video camera captures the image allowing the software to determine the contact angle between the drop and the surface with time, by recurring to mathematic functions as Young- Laplace [177].

A contact angle inferior to $90^{\circ}$ indicates that the liquid spreads over a large area of the surface (wetting the surface), while a contact angle superior to $90^{\circ}$ indicates that the liquid minimizes the contact with the surface (unfavorable for wetting the surface) [178]. This way, providing information about the nature of the surface, hydrophobic or hydrophilic (Figure 3).

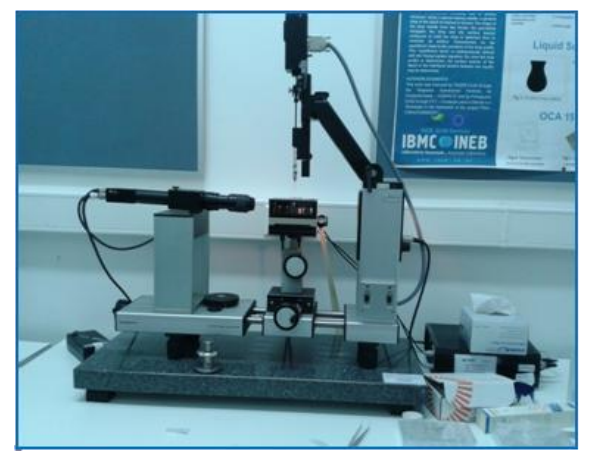

(A)

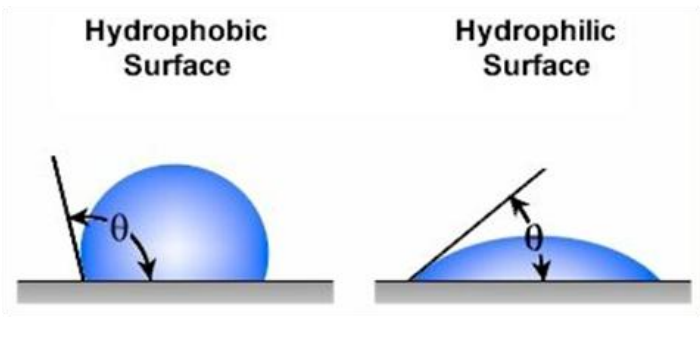

(B)

Figure 19- Contact angle measurement equipment (A). Contact angle observed in a hydrophobic and a hydrophilic surface (B) (adapted from [179]). 


\subsection{Ellipsometry}

Ellipsometry is an optical technique that measures changes in the state of polarization of the light upon reflection from a surface. If the surface was coated with an ultrathin film $(<100 \mathrm{~nm})$ this technique can measure the thickness of the film through the alteration on the state of polarization of the light in comparison with the same measure on the surface without coating.. A plane-polarized laser beam, emitted by a source light is usually reflected from the coated surface and its polarization analyzed with a compensator/detector couple (Figure 20). This change in polarization state depends on the film thickness, the refractive index, which is a measure of the bending of a ray of light when passing from one medium into another, and the extinction coefficient that is a measure of the rate of diminution of transmitted light via scattering and absorption for a medium [180].

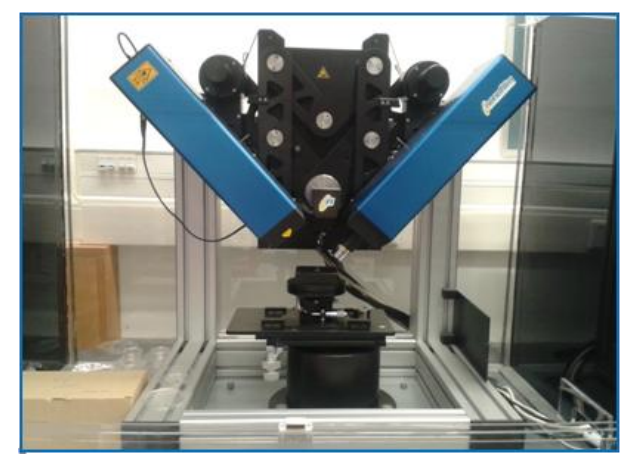

(A)

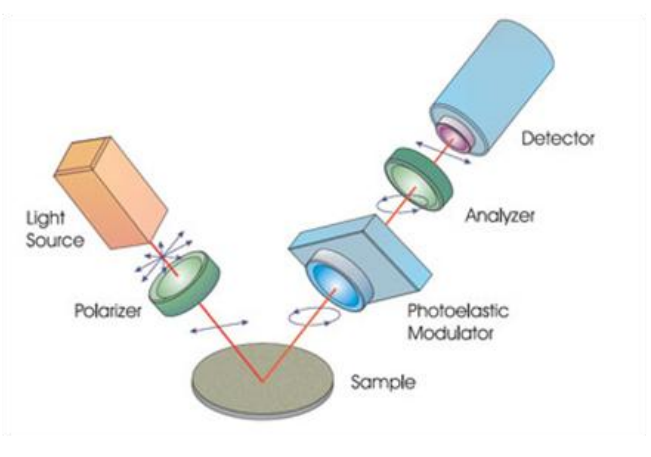

(B)

Figure 20- Ellipsometer equipment (A). Schematic representation of the ellipsometer setup (B) [181].

\subsection{X-ray Photoelectron Spectroscopy (XPS)}

XPS is a spectroscopic technique based on the photoelectric effect, a phenomena that happens when a material is exposed to electromagnetic radiation emitting an electron.

This technique measures the elemental composition in a surface. XPS measures the kinetic energy and the number of inner shell photoelectrons that escape from the material surface irradiated with mono-energetic $x$-rays beam in ultra high vacuum (Figure 21).

The energy of the emitted core level electrons is measured and its value provides information about the nature and environment of the atom from which it came, according to the equation below:

$\mathrm{BE}=h v-\mathrm{KE}$

Where,

$\mathrm{BE}$ is the energy binding the electron to an atom (value we want to know)

$\mathrm{KE}$ is the kinetic energy of the emitted electron (value measured)

$h v$ is the energy of the X-rays, a known value. 
There is an energy characteristic for every chemical element that can be used to determine the elemental composition of a sample. The photoelectrons are detected by a electron detector and its energy is measured by an electrostatic analyzer. By analyzing the energy and intensity of the photoelectron peaks is possible to obtain several information about the identity, chemical state and quantity of each element present [14]. The ultra high vacuum chamber is also an important component since it keep a sterile environment assuring the absence of other elements during the analysis, and, consequently, assumes that all the detected elements belong to the sample in analysis [18].

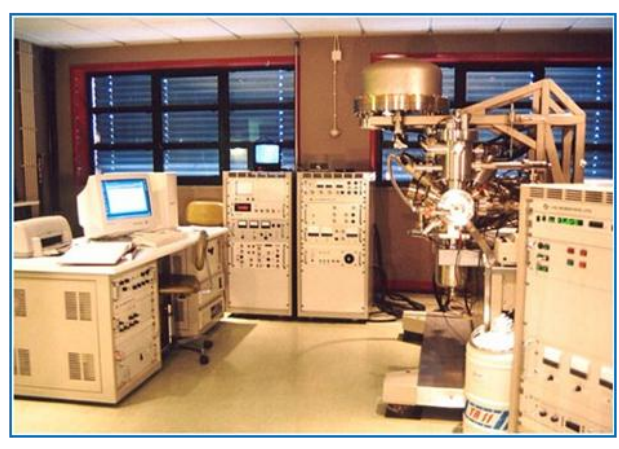

(A)

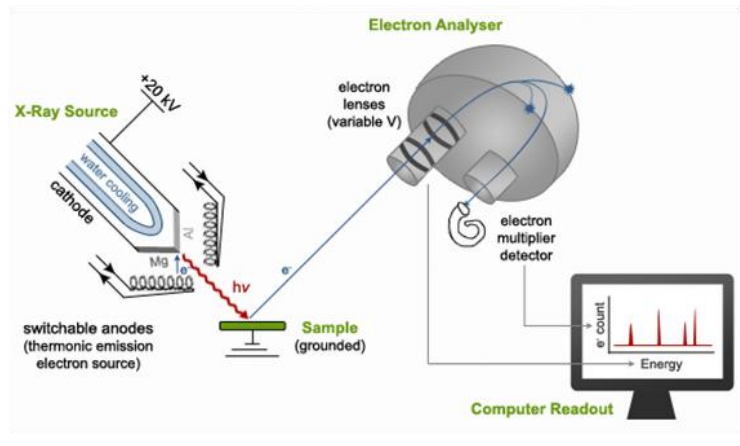

(B)

Figure 21- XPS equipment (A). Schematic representation of XPS components in detail (B), adapted from [182].

\subsection{Attenuated Total Reflection - Fourier-Transform InfraRed Spectroscopy (ATR-FTIR)}

ATR-FTIR is a chemical imaging technique to identify and quantify functional groups in molecules. Here, a sample is crossed by infrared radiation being part of the radiation absorbed by the sample and the other part transmitted. The resultant spectrum represents the molecular absorption and transmission characteristic of each sample analyzed. It also works as a fingerprint of the sample with absorption peaks that represent the frequencies of vibration between the bonds of the atoms [183].

There are different sample handling techniques in FTIR, however, the one used in this work was ATR. The method applied depends mainly on the nature of the sample, and in ATRFTIR spectroscopy an attenuated total reflection accessory operates by measuring the changes that occur in a totally internally reflected infrared beam when the beam comes into contact with a sample (Figure 22) [184]. 


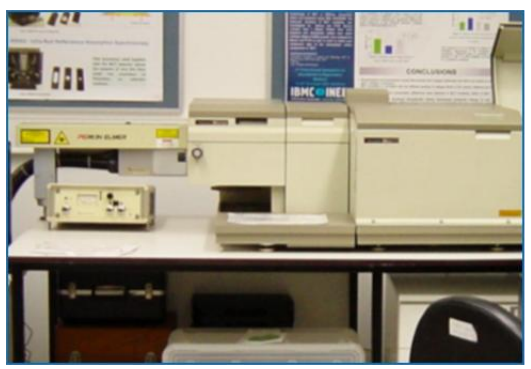

(A)

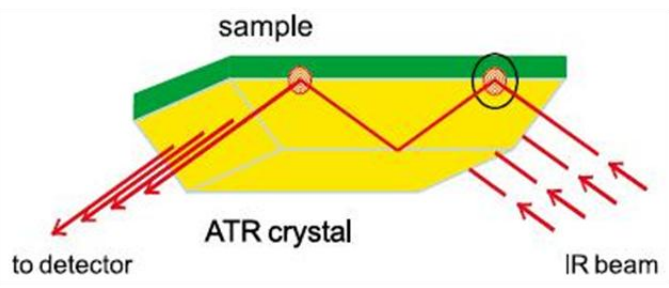

(B)

Figure 22- ATR-FTIR equipment (A). Schematic representation of sample analysis with ATR-FTIR spectroscopy (B) (adapted from [185]).

\subsection{Quartz Crystal Microbalance with Dissipation (QCM-D)}

QCM-D is an equipment that uses a simple and efficient technique based on the piezoelectric effect (Figure 23). Piezoelectricity is the capacity of some crystals to generate an electrical tension in response to a mechanical pressure. Quartz is one of the materials with this capacity, and gathering with other particularities, makes it perfect for QCM-D applications. Indeed, it is possible to excite the crystal and make it oscillate by applying an AC potential difference between the two electrodes. Therefore, with this equipment it is possible to evaluate mass variation per area unit by measuring frequency changes of a quartz crystal resonator.

The sensor that measures these variations is composed of the quartz crystal placed between two electrodes that can apply an alternating voltage on the sensor causing it to oscillate at a specific frequency. The frequency of oscillation depends on the thickness of the crystal; thus, a mass alteration on the surface of the crystal will lead to a frequency change: for example, when a mass is deposited on the quartz crystal the thickness increases, provoking a decrease in the oscillation frequency. The total mass oscillating includes the adherent material on the surface and the water coupled to the material [186].

This relationship between frequency changes and mass alteration is explained by the Sauerbrey equation:

$$
\Delta f=-C \cdot \Delta m,
$$

Where,

$\Delta f$ is the observed frequency change in $\mathrm{Hz}$

$\Delta m$ is the change in mass per unit area in $\mathrm{g} / \mathrm{cm}^{2}$

$C$ is the sensitivity factor for the crystal $\left(17.7 \mathrm{ng} / \mathrm{s} . \mathrm{cm}^{2}\right)$.

For the Sauerbrey relationship to work it needs to respect some assumptions, (1) the adsorbed mass must be much smaller than the mass of the quartz crystal, and (2) should be evenly distributed on the crystal surface. Besides, the deposited mass should not affect the vibration mode of the crystal, which is only valid for rigid layers as those do not display vibrational frequency; this relation can only be applied to rigid adherent masses.

Some QCM-D are also equipped with dissipation factor monitoring, QCM-D. The dissipation factor relates to the viscoelastic properties of the sample and is measured simultaneously with the frequency to help the analysis. 
QCM-D has a wide range of applications in different fields of investigation as biomaterials, environment, cellular and molecular biology, biofuels, among others. This equipment, allows a real-time analysis of surface phenomena as film formation, molecular adsorption or interactions on various surfaces. It can be used to evaluate protein adsorption, cell attachment, biomineralizaton, polyelectrolyte multilayers, hemocompatibility, etc. One of the main applications of QCM-D is in the analysis and investigation of biomaterials [187]. In this work, we used QCM-D to evaluate the stability of films/coatings and quantify protein adsorption related to hemocompatibility.

There are several types of QCM-D but the model used in this work was the Q-Sense E4 by Bioloin Scientific. This model presents 4 channels for quartz crystals, allowing a rapid and efficient analysis of molecular interactions in four different crystals.

The electrodes are placed into a chamber specifically designed for controlled flow measurements and constant temperature. The liquid injection or extraction and its flow rate are controlled by a pump external to this chamber and that can be controlled by the operator. The crystals used in this equipment can be prepared with different coatings like gold, silicon dioxide, stainless steel, titanium, etc., according to the objective of the measurement [187].

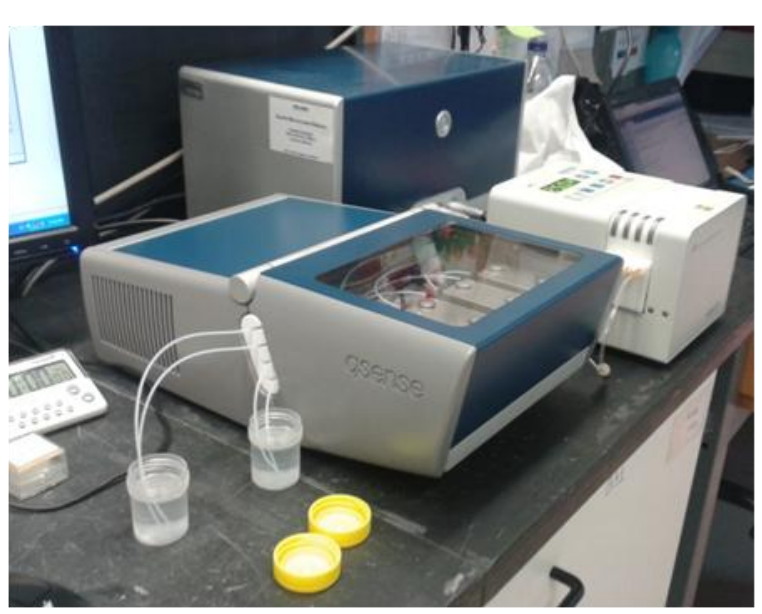

(A)

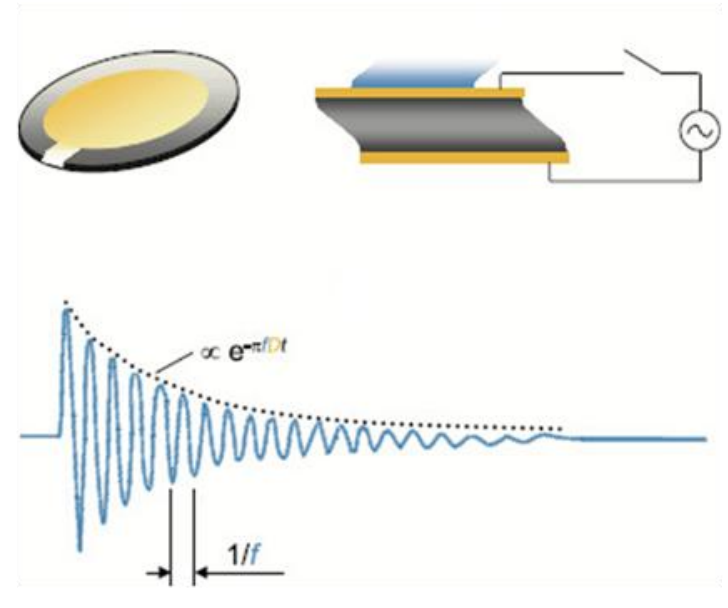

(B)

Figure 23- $Q C M-D$ equipment $(A)$. Schematic representation of a QCM-D crystal and sensing principle (B) (adapted from [188]). 


\section{Chapter 4}

\section{Materials and Methods}

\subsection{Surfaces Preparation}

PU films were prepared by casting (4.1.2.1) and PU ultrathin coatings deposited on top of gold substrates and gold sensors, were produced by spin coating. The use of gold surfaces allowed the application of characterization techniques like ellipsometry and QCM-D. In Figure 24 it is possible to see the different sort of samples used: a PU film, a gold substrate and a gold sensor.

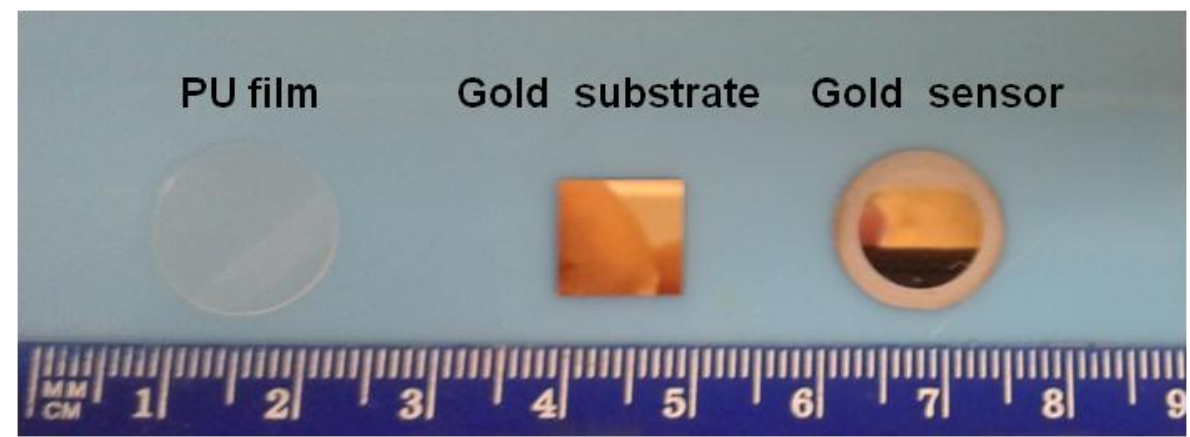

Figure 24- Gold substrate and sensor on which PU ultra thin films were produced and PU film produced by casting.

\subsubsection{Polyetherurethane (PU)}

PU, Pellethane 236380 AE (Figure 25), was commercially obtained in the form of pellets from Dow Chemical. Pellets were cleaned twice with hexane and once with ethanol (15 min sonication) to eliminate any trace of silicone used during the pellets processing. This process was repeated twice. After, PU pellets were dried overnight in a vacuum oven at room temperature (RT). 


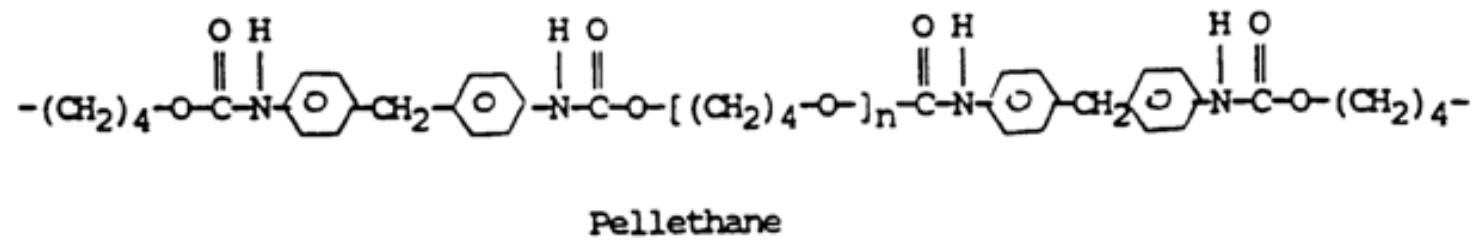

Figure 25- Pellethane chemical structure. Adapted from [189].

\subsubsection{PU Processing}

\subsubsection{PU Films Casting}

PU films were prepared as previously described [190]. PU was dissolved at $12.5 \%$ in tetrahydrofuran (THF, Sigma) and $40 \mathrm{~mL}$ of the solution were casted onto clean glass petri dishes of $140 \mathrm{~mm}$ of diameter. THF was left to evaporate overnight and, then, thin films were cut in small disks of $13 \mathrm{~mm}$ of diameter and washed 3 times with $\mathrm{ddH}_{2} \mathrm{O}$ (water type 2) (5 min sonication) to remove possible impurities from the cutting process. After, $2 / 3$ of the PU films were sent to Matera, a company located at Biocant Park in Cantenhede for CM immobilization and the other $1 / 3$ was used as control.

\subsubsection{PU Ultrathin Coatings (Spin Coating)}

PU solution at $0.1 \%$ was prepared by dissolving PU pellets in THF. Drops of $80 \mu \mathrm{L}$ were dispensed on the center of gold surfaces (substrates or sensors cleaned according to the described below) strategically positioned in the spin coater equipment. Its process of work can be observed in Figure 26. Surfaces were spun at $9000 \mathrm{rpm}$ for $1 \mathrm{~min}$. PU coated surfaces were then left to dry in a vacuum oven at RT for $1 \mathrm{~h}$. After, 2/3 of the PU coated surfaces were sent to Matera, at Biocant Park in Cantenhede for CM immobilization and the other $1 / 3$ was used as control.

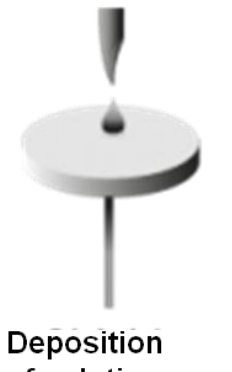

of solution

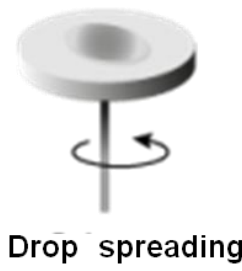

by rotation

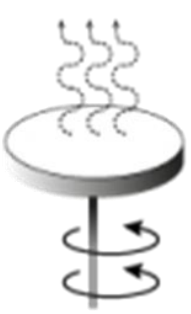

Solvent evaporation

Figure 26- Spin coating working principle. 


\section{a) Gold Substrates for Ellipsometry (Cleaning Process)}

Gold coated silicon wafers, of $1 \times 1 \mathrm{~cm}^{2}$ (Figure 27) were obtained from INESC Microsystems \& Nanotechnologies (INESC-MN) and prepared as previously described by our group [191]. To prevent contamination during dicing, storage and transport, gold substrates were coated with a $1.2 \mu \mathrm{m}$ layer of positive photoresist (reference PFR7790, from JSR) soluble in acetone.

Prior to use, gold substrates were washed to remove both the photoresist and possible organic residues. First, gold substrates were immersed in $10 \mathrm{~mL}$ of acetone $(99.5 \%$ Merck Millipore) and sonicated for $3 \mathrm{~min}$ using polypropylene (PP) flasks. This step was repeated twice. Then, they were rinsed with absolute ethanol (99.9\% Merck Millipore) to eliminate all traces of acetone and were immersed in "piranha" solution (7 parts concentrated sulfuric acid and 3 parts hydrogen peroxide (at 30\% vol., VWR) for 5 min (Note: this solution reacts violently with many organic materials, namely with acetone, and should be handled with care)[78]. Gold substrates were afterwards transfer to new PP flasks, immersed in absolute ethanol and sonicated for another $3 \mathrm{~min}$. This step was repeated once more using Milli-Q water (type 1). At the end, gold substrates were rinsed with ethanol and dried with a gentle argon stream.

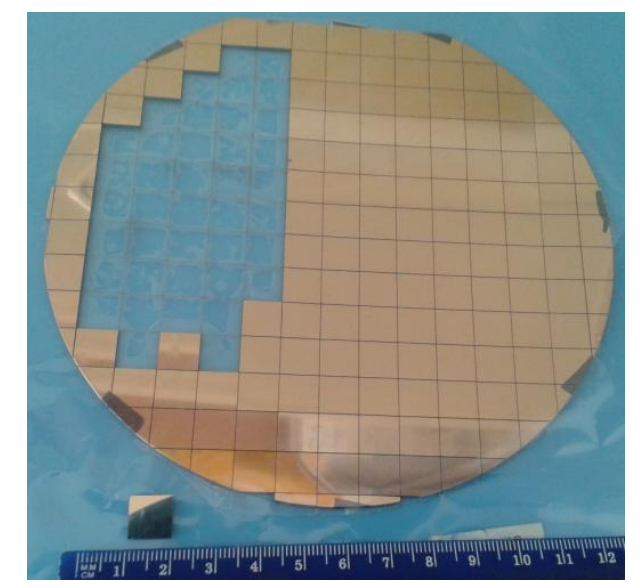

Figure 27- Gold coated silicon wafer where gold subtracts were extracted from.

\section{b) Gold Sensors for QCM-D (Cleaning Process)}

Gold coated sensors, with fundamental resonance of $5 \mathrm{MHz}$, were purchased from Q-Sense (Biolin Scientific) and used as received. For consecutive testing, pre-used sensors were washed as follows: first, sensors were oxidized in an ultra violet (UV) oven for $10 \mathrm{~min}$; then immersed for $5 \mathrm{~min}$ in a solution containing: $10 \mathrm{~mL}$ of water type 1 with $2 \mathrm{~mL}$ ammonia (Merck, 25\%) and $2 \mathrm{~mL}$ hydrogen peroxide solution (30\% vol.) heated at $75^{\circ} \mathrm{C}$. Finally, sensors were rinsed and sonicated for $3 \mathrm{~min}$ in water type 1. 0-rings from the QCM-D system were sonicated with 2\% Hellmanex for $3 \mathrm{~min}$, rinsed and sonicated twice for $3 \mathrm{~min}$ in water type 1. In the end, both sensors and 0-rings were dried with argon stream and stored at RT in an 
oxygen free environment. In Figure 28, it is possible to see the flow module of QCM-D with the O-ring and gold sensor.

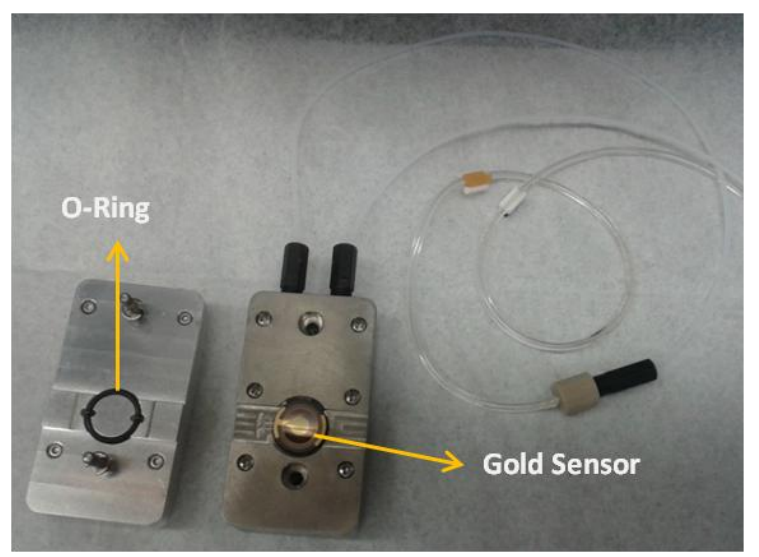

Figure 28- Flow module of a QCM-D with an 0-ring and a gold sensor.

\subsubsection{Immobilization onto PU}

\subsubsection{Au NPs Synthesis and Immobilization onto PU Surfaces}

Au NPs were synthesized by the Turkevich's method [192]. Briefly, $90 \mathrm{~mL}$ of $10^{-4} \mathrm{M}$ Chloroauric Acid $\left(\mathrm{HAuCl}_{4}\right)$ solution were mixed with $10 \mathrm{~mL}$ of a solution containing $0.2 \mathrm{mg}$ sodium citrate (Sigma) and left boiling until the color of the solution changed from light yellow to ruby-red.

Polyurethane films were cleaned with $20 \%$ ethanol aqueous solution and subsequently with water type 1. After, $\mathrm{PU}$ films were immersed in Silicon tetrachloride $\left(\mathrm{SiCl}_{4}\right)$ in anhydrous toluene solution (5\%) for $5 \mathrm{~min}$, washed with ethanol to remove excess $\mathrm{SiCl}_{4}$ and were left at RT for $24 \mathrm{~h}$, to allow hydrolysis to occur, creating free hydroxyl groups on PU surface. Then, PU films were immersed in $1 \%(\mathrm{v} / \mathrm{v}) 3$-amino propyltrimethoxysilane (APTMS) prepared in an ethanolic solution $(4 \%(\mathrm{v} / \mathrm{v}))$ ethanol in water type 1 with $\mathrm{pH} \sim 4.5$ adjusted with acetic acid) for $30 \mathrm{~min}$ and washed with ethanol. Then, APTMS treated films were incubated in the solution of Au NPs for $24 \mathrm{~h}$. At the end, PU-Au NPs were washed twice with water type 2 and dried with argon. Au NPs coated surfaces were used as control in characterization techniques.

\subsubsection{Covalent Immobilization of CM onto PU Surfaces}

CM peptide with a cysteine at the $C$ terminal (KWKLFKKIGAVLKVLC) was purchased from Caslo Laboratory, Denmark with $98 \%$ purity. CM immobilization onto PU was conducted as previously described [118]. In few words, PU-Au NPs were functionalized with polyethylene glycol (PEG)-spacers, HS-PEG-NH ${ }_{2}$ and HS-PEG-COOH (1:1 molar ratio) (1 kDa, $0.9 \mathrm{mM}, 1$ $\mathrm{mg} / \mathrm{mL}$ ) for $24 \mathrm{~h}$. Unbound molecules were removed by rinsing with water type 1 . Then, surfaces were incubated in $\mathrm{N}$-[ $\gamma$-maleimidobutyryloxy]sulfosuccinimide ester solution (sulfoGMBS, $1 \mathrm{mg} / \mathrm{mL}$ in $100 \mathrm{mM}$ phosphate buffer at $\mathrm{pH} 7.2$ ) for $2 \mathrm{~h}$ to modify the amine groups and expose maleimide groups that will bind to HS-groups of $\mathrm{CM}$ (obtained by the introduction of a cysteine residue at $\mathrm{C}$-terminal). Activated surfaces were then immersed into $\mathrm{CM}$ peptide 
solution (1-3 mg/mL in phosphate buffer $(\mathrm{pH} \mathrm{7.2))} \mathrm{for} \mathrm{covalent} \mathrm{immobilization,} \mathrm{during} 24 \mathrm{~h}$ at $4^{\circ} \mathrm{C}$. Unbound peptide was removed by rinsing with phosphate buffer.

The amount of peptide immobilized was estimated using the sulfosuccinimidyl-4-0-(4,4dimethoxytrityl)butyrate (sulfo-SDTB) test according to manufacturer instructions [118], [153]. A schematic representation of immobilization process can be observed in Figure 29 (A), and is possible to see in the final step we obtain a zwitterionic surface. A zwitterionic surface has positively and negatively charged groups, and in this case, the surface will have positive charge from the $\mathrm{CM}$ peptide and negative charge from the $\mathrm{COOH}$ group.

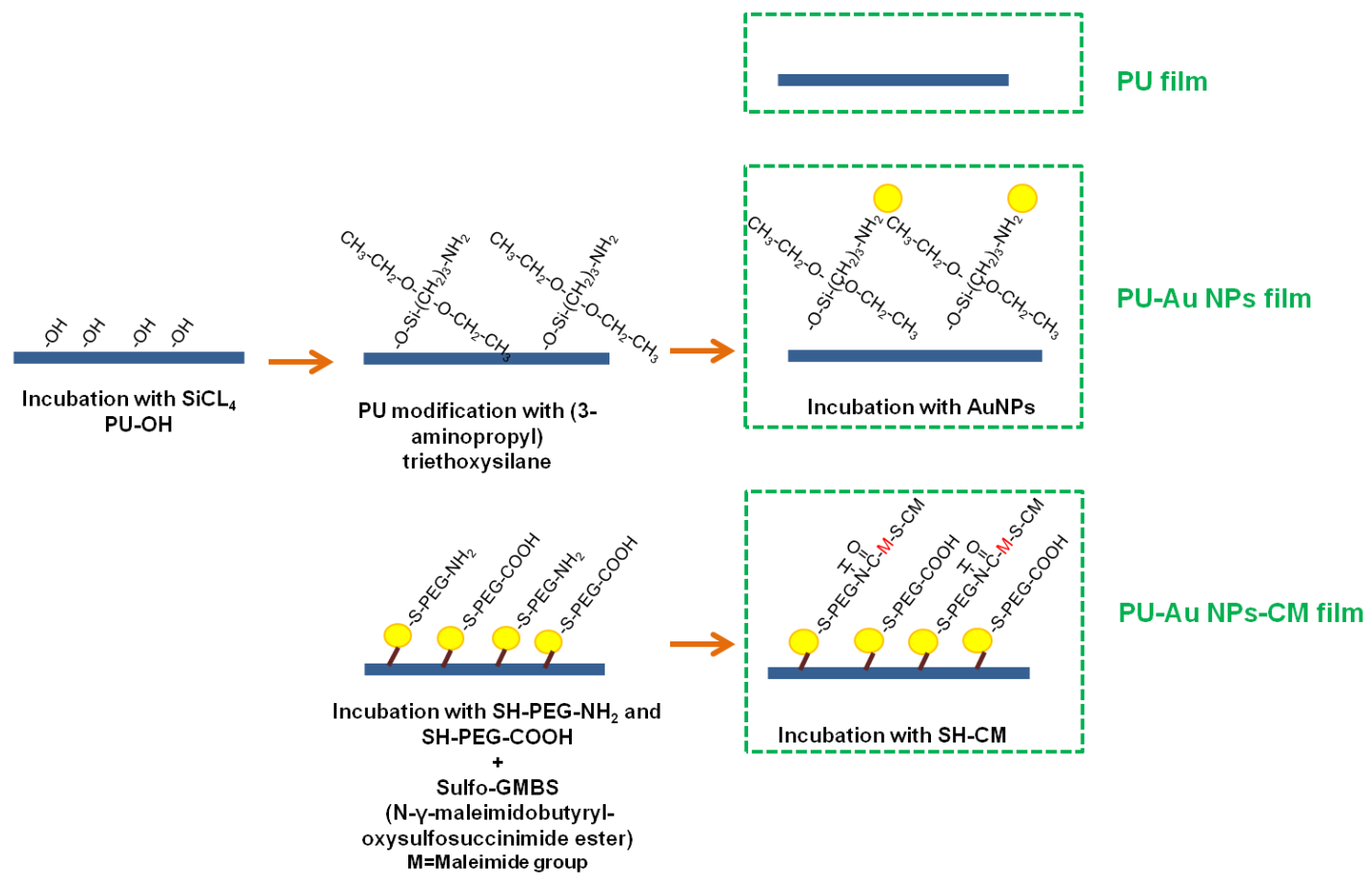

(A)

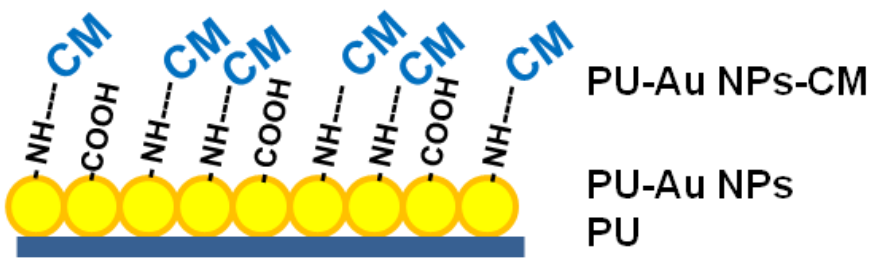

(B)

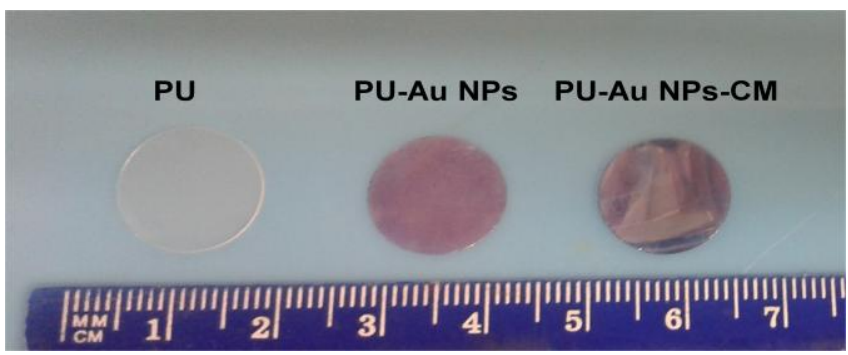

(C)

Figure 29- Schematic representation of the PU surfaces modification with Au NPs and CM (A). Final scheme of CM immobilization on PU (B). PU films before (PU) and after surface modification (PU-Au NPs and PU-Au NPs-CM) (B). 


\subsubsection{Physical Incorporation of MSI-78-derived Peptides into PU Films}

MSI-78 derived peptides, MSI-78 (1-17) and MSI-78 (2-18), were incorporated in PU films during casting. MSI-78 peptides were prepared at 32,64 and $128 \mu \mathrm{g} / \mathrm{mL}$ in $25 \mathrm{~mL}$ of THF. Vancomicin (Sigma), an antibiotic, was prepared at $64 \mu \mathrm{g} / \mathrm{mL}$ in $25 \mathrm{~mL}$ of THF and used as a second control. After peptide dissolution, PU pellets, treated as described in section 4.1.1, were added to the peptide solution. Once the PU pellets were completely dissolved, the 25 $\mathrm{mL}$ of solution were casted onto clean glass petri dishes of $80 \mathrm{~mm}$ of diameter. THF was left to evaporate overnight. The produced films were cut in small disks of $13 \mathrm{~mm}$ of diameter, inside a flow chamber to prevent contamination.

\subsection{Surface Characterization}

\subsubsection{Scanning Electron Microscopy (SEM)}

Surface micrographies of PU, PU-Au NPs and PU-Au NPs-CM films were taken using a high resolution SEM with X-ray Microanalysis, JEOL JSM 6301F/Oxford INCA Energy 350 at CEMUP (Centro de Materiais da Universidade do Porto). An electron beam intensity of $5 \mathrm{kV}$ (accelerating voltage) was used and images were taken at 2,000x and 200,000x magnification. To increase the surfaces conductivity, the films were sputtered with Au/Pd for 60 seconds and $15 \mathrm{~mA}$ current using the SPI Module Sputter Coater equipment.

Platelet adhesion was examined with beam intensity at $10 \mathrm{kV}$ and magnifications of 2,000x and 4,000x. Again, surfaces were pre-coated with Au/Pd for 60 seconds at a $15 \mathrm{~mA}$ current.

\subsubsection{Water Contact Angle Determination}

Water contact angle measurements were performed using a Data Physics, Model OCA 15, equipped with video CCD-camera. Samples (PU, PU-Au NPs and PU-Au NPs-CM) were placed in a closed thermostated chamber $\left(25^{\circ} \mathrm{C}\right)$ saturated with water type 2 to prevent droplet evaporation. $4 \mu \mathrm{L}$ water type 2 droplets (syringe) were placed on the surface of each film and the angle measured using the sessile drop method. Angle variations with time were recorded during $3 \mathrm{~min}, 30$ times per second using the SCA 20 software. Droplet profiles were fitted using the Young-Laplace mathematical function. The contact angle respective to each film was calculated by extrapolating the time-dependent curve to zero [193]. 3 replicates of each (PU, PU-Au NPs and PU-Au NPs-CM) were analyzed.

\subsubsection{Ellipsometry}

Ellipsometry measurements were performed using an ellipsometer from Nanofilm Surface Analysis, model $\mathrm{EP}^{3}$. The light source was a laser of wavelength of $532 \mathrm{~nm}$. The gold sample refractive index $(n)$ and extinction coefficient $(k)$ were determined by using delta and psi 
spectrum with variation of angle between $66^{\circ}$ and $76^{\circ}$. The measurements were made in four zones to confirm a correct alignment, on 3 samples. To determine the thickness of PU, the $n$ and $k$ of the gold substrates were set as 0.6647 and 2.6112 respectively [194], and the final angle used was $71^{\circ}$. Assays were performed using 3 replicates of each sample (PU and PU-Au NPs).

\subsubsection{X-ray Photoelectron Spectroscopy (XPS)}

XPS measurements were conducted using a VG Scientific ESCALAB 200A (UK) spectrometer with an AlKa X-ray source of $1486.6 \mathrm{eV}$, operating at $15 \mathrm{kV}$ (300W) to estimate photoemission (CEMUP). Photoelectrons were analyzed at a $55^{\circ}$ takeoff angle and at $100 \AA$ of the outermost layer. Survey scans were acquired with a pass energy of $50 \mathrm{eV}$. High-resolution spectra of carbon $(C)$, nitrogen $(N)$, oxygen $(0)$, sulfur $(S)$, silicon $(\mathrm{Si})$ and gold $(\mathrm{Au})$ were collected with analyzer energy of $20 \mathrm{eV}$. These were resolved into individual Gaussian peaks using the XPSPEAK 4.1 software and fitted by setting the maximum of the resolved $\mathrm{C}(1 \mathrm{~s})$ peak, correspondent to $\mathrm{C}$ in a hydrocarbon environment $(\mathrm{CHx})$, to $285.0 \mathrm{eV}$.

\subsubsection{Fourier Transformed Infrared - Attenuated Total Reflectance (ATR- FTIR)}

ATR- FTIR measurements were performed with a Perkin Elmer FTIR spectrophotometer, model 2000. To realize the measurements an ATR accessory (SplitPea) was used. This accessory is configured to apply localized, measured pressure to produce superior contact between the sample and the ATR crystal, so the PU films were gently pressed against the crystal during readings. Infrared spectra for each sample were obtained by performing 100 scans with a resolution of $4 \mathrm{~cm}^{-1}$.

\subsection{QCM-D Testing}

\subsubsection{Stability of Au NPs and CM Coating}

The stability of the Au NPs and CM coatings on PU was tested by QCM-D. Sterile phosphate buffered saline solution (PBS) at $\mathrm{pH}=7.4$ was continuously injected into the QCM-D system with gradually increasing flow rates, that changed every hour: 12.5, 25, 50, 75, 100, 150 and $200 \mu \mathrm{L} / \mathrm{min}$. Tests lasted 7 hours. Au NPS and CM-coated sensors were tested after immobilization in two different types of PU: PU unmodified (P_U) and PU chemically activated with SiCl4 (PU_ChA). This allows us to understand if PU treatment influences Au NPs and $C M$ immobilization and consequently their stability on its surface. Results were reported both in frequency variation $(\Delta \mathrm{f})$ and mass $\left(\mathrm{ng} / \mathrm{cm}^{2}\right)$, according to Sauerbrey equation explained in section 3.6 . 


\subsubsection{Adsorption of Blood Plasma}

Adsorption of proteins from blood plasma on the differently treated QCM-D sensors was monitor in real time using the QCM-D system. PBS was used as baseline and left for $\approx 10 \mathrm{~min}$ in contact with the sensors. $1 \%$ human plasma (provided by Centro Hospitalar de São João, HSJ, Porto) in PBS was then added and left to adsorb until saturation (up to $3 \mathrm{~h}$ ). The entire experiment was conducted at $37^{\circ} \mathrm{C}$ and $25 \mu \mathrm{L} / \mathrm{min}$. Data are reported as frequency variation $(\Delta \mathrm{f})$ and mass $\left(\mathrm{ng} / \mathrm{cm}^{2}\right)$, according to Sauerbrey equation explained in section 3.6.

After each protein adsorption tests, the modules composing the QCM-D system were cleaned. Each module was flushed with $2 \%$ Hellmanex in $\mathrm{ddH}_{2} \mathrm{O}$ for $10 \mathrm{~min}$ at $400 \mu \mathrm{L} / \mathrm{min}$ (to remove the protein layer from both sensors and modules) and water type 1 for another $20 \mathrm{~min}$ at equal flow rate. To clean the QCM system, sensors and O-rings were substituted by others sensors and O-rings that are only used for cleaning the system and each module was flushed with $2 \%$ Hellmanex (10 $\mathrm{min}$ ) and water type 1 (20 $\mathrm{min}$ ) at $400 \mu \mathrm{L} / \mathrm{min}$.

Finally, the cleaning sensors and 0 -rings were removed and the modules were dried with compressed air.

\subsection{Platelets Adhesion and Activation}

Samples were sterilized by their immersion in 70\% ethanol (Valente e Ribeiro, Lda.) for 15 min. This step was repeated and after, surfaces were dried with argon in sterile environment. Sterilized samples were then pre-immersed in PBS or $1 \%$ human plasma (in PBS) for 30 minutes at $37^{\circ} \mathrm{C}$ and then washed 3 times with PBS. Simultaneously, 24-well tissue culture polystyrene (TCPS) plates (Sarstedt) were blocked with $1 \%$ bovine serum albumin (BSA) in PBS for 1 hour at $37^{\circ} \mathrm{C}$, under static conditions. TCPS plates were then washed five times with PBS. Films were then incubated with freshly prepared platelet solution at $3 \times 10^{8}$ platelets $/ \mathrm{mL}$ in PBS for 30 minutes at $37^{\circ} \mathrm{C}(70 \mathrm{rpm})$ on the BSA-blocked TCPS plates. After incubation, samples were washed three times with PBS. Adhered platelets were fixated with $1.5 \%$ glutaraldehyde (Merck) in $0.14 \mathrm{M}$ sodium cacodylate (Merck) buffer for $30 \mathrm{~min}$ at RT and then rinsed twice with water type 2 . After, the films were dehydrated in a growing ethanol/water gradient, $50 \%-99 \%$ followed by critical point drying. The amount of adhered platelets and its degree of activation was followed by SEM by counting the number of platelets on 5 images collected at different sections of each film. Results were reported as number of platelets $/ \mathrm{mm}^{2}$ or percentage per degree of activation. A scale of platelet degree of activation can be observed below in Figure 30.
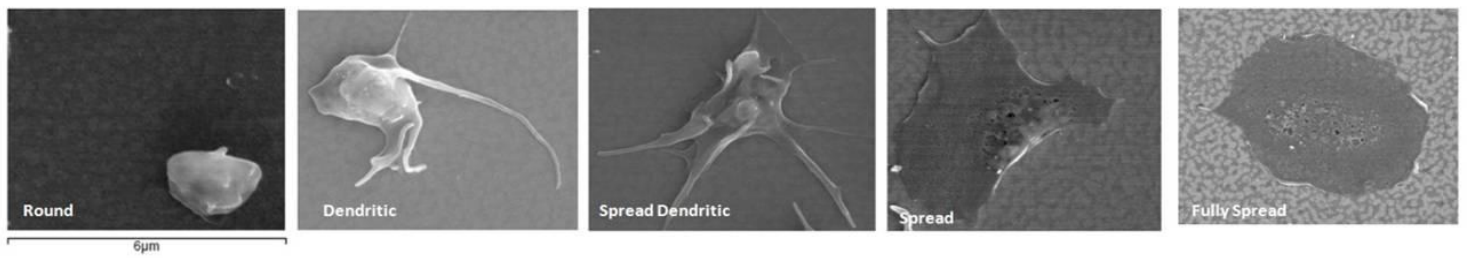

Figure 30 - SEM images illustrating the five types of platelet shapes, from less activated to the most activated state. round or discoid (R); dendritic or early pseudopodial (D); spread-dendritic or intermediate pseudopodial (SD); spread or late pseudopodial (S) and fully spread (FS). Scheme produced with original images based on [54]. 


\subsection{Antimicrobial and Anti-Adhesive Properties of CM Coatings}

\subsubsection{Bacteria Strains and Growth Conditions}

Staphylococus epidermidis (ATCC 35984), clinical isolated from an infected catheter and high slime producer, was obtained from the American Type Culture Collection. Bacteria were grown in trypticase soy agar (TSA, Merck) plates overnight at $37^{\circ} \mathrm{C}$ (bacteria spreading) and trypticase soy broth (TSB, Merck) overnight at $37^{\circ} \mathrm{C}$ and $150 \mathrm{rpm}$ (bacteria inoculum).

\subsubsection{Bacterial Adhesion}

Surfaces were sterilized with ethanol $70 \%$ for $30 \mathrm{~min}$ in 24-well TCPS plates and then washed 3 times with PBS. After, surfaces were dried with argon in sterile environment. Films were incubated in PBS or $1 \%$ human plasma (in PBS) for 30 min at $37^{\circ} \mathrm{C}$. After washing 3 times with PBS samples were incubated in $1 \mathrm{~mL}$ of bacteria solution with $1 \times 10^{7}$ Colony-Forming Units (CFUs) $/ \mathrm{mL}$ in PBS for $2 \mathrm{~h}$ at $37^{\circ} \mathrm{C}$. After adhesion, bacteria solution was removed and the samples were washed 3 times with PBS. Bacteria adhered to the surfaces were fixated with 4\% paraformaldehyde in PBS for 20 min at RT. After, surfaces were washed 3 times with PBS, mounted in slides and stained with VECTASHIELD Mounting Medium with 4',6-diamidino2-phenylindole (DAPI; Vector). Samples were stored at $-20^{\circ} \mathrm{C}$ protected from the light until observation in the inverted fluorescence microscope (Axiovert $200 \mathrm{M}$, Zeiss, Germany). The number of bacteria $/ \mathrm{mm}^{2}$ was determined by counting the number of bacteria found in ten fields of $0.01 \mathrm{~mm}^{2}$, per sample, using the ImageJ software.

\subsubsection{Bacteria Viability}

Viability of adherent bacteria was assessed using the LIVE/DEAD ${ }^{\circledR}$ Bacterial Viability Kit (BaclightTM). Surfaces were challenged with bacteria as described in 4.5.2. After incubation with the bacterial suspension, surfaces were washed twice with PBS and once with $0.85 \%$ Sodium Chloride $(\mathrm{NaCL})$. Then, surfaces were stained with a combination of two dyes, redfluorescent propidium iodide (excited at $535 \mathrm{~nm}$ ) and green-fluorescent syto 9 (excited at 485 $\mathrm{nm}$ ) for $15 \mathrm{~min}$ at RT, protected from light, according to manufacturer instructions. Propidium iodide (red) labels only dead bacteria, since it only penetrate damaged membranes, whereas syto 9 (green) labels nucleic acids of both live and dead bacteria. Finally, surfaces were mounted in slides using VECTASHIELD with DAPI for microscopy observation. Images were obtained with an inverted florescence microscope. The number of bacteria $/ \mathrm{mm}^{2}$ was determined by counting the number of bacteria found in ten fields of 0.01 $\mathrm{mm}^{2}$, per sample, using the ImageJ software.

\subsection{Antimicrobial Activity of PU Films Containing MSI-78 (1-17) and MSI-78 (2-18)}

Antimicrobial activity of the PU films containing AMPs was evaluated by a bacterial adhesion assay modified from Pallavicini et al [195]. Surfaces were placed in a 24-well TCPS plate and a drop of $10 \mu \mathrm{L}$ of bacterial suspension adjusted to $1 \times 10^{7} \mathrm{CFUs} / \mathrm{mL}$, in PBS or $1 \%$ 
human plasma, was placed on top of each sample. Subsequently, the bacterial suspension was covered by a sterilized glass coverslip (VWR) of equal diameter, facilitating contact between the microorganisms and the surface. After $5 \mathrm{~h}$ incubation at $37^{\circ} \mathrm{C}$ in wet environment, $1 \mathrm{~mL}$ of PBS was added to each well. Films were re-suspended until detachment of the coverslip was observed. After that, the coverslip was removed and a series of dilutions from $10^{0}$ to $10^{-5}$ of the supernatant were done to count the number of CFUs. For that, three drops of $10 \mu \mathrm{L}$ each per dilution factor were plated in TSA containing Petri dishes and placed in an incubator overnight at $37^{\circ} \mathrm{C}$.

\subsection{Statistical Analysis}

Statistical analysis was performed using ANOVA or Paired t-test. Data is expressed as the mean \pm standard deviation (SD) and $p$ values $<0.05$ were considered significant, with * corresponding to $p<0.05,{ }^{* *}$ corresponding to $p<0.01,{ }^{* * *}$ corresponding to $p<0.001$ and ${ }^{* * * *}$ corresponding to $p<0.0001$. 


\section{Chapter 5}

\section{Results and Discussion}

\subsection{Surfaces Characterization}

\subsubsection{Stability of Coatings}

To evaluate the stability of the Au NPs and CM coatings on PU, a QCM-D test was performed using PU-coated QCM gold sensors under injection of $\mathrm{PBS}\left(37^{\circ} \mathrm{C}\right)$ at increasing velocities, from 12.5 to $200 \mu \mathrm{L} / \mathrm{min}$, for 7 hours. With this assay, it is expected to evaluate the importance of the chemical activation of PU film, before Au NPs immobilization, on the resistance of the coatings under flow conditions and predict their stability in a dynamic cardiovascular system. QCM-D translates alterations on the frequency of vibration of the quartz crystal into mass changes. The increase of its frequency of vibration is translated into mass loss, while its decrease is translated into mass gain. Moreover, higher frequency variation indicates higher mass changes.

Figure $31 \mathrm{~A}$ and $\mathrm{B}$ show the frequency of vibration profiles registered on PU-Au NPs and PU-Au NPs-CM, respectively. Stability tests were conducted using PU that was firstly chemically activated with $\mathrm{SiCl}_{4}$ (as explained in section 4.1.3.1) (chemically activated PU; PU_ChA) before Au NP and CM immobilization, and PU that was not pre-activated (unmodified PU; PU_U).

Results showed an increase of the frequency of vibration of sensors coated with PU-Au NPs and PU-Au NPs-CM, if PU surfaces were not chemically activated (PU_U). These alterations were visible after $300 \mathrm{~min}$, when the flow rate was changed from 75 to $100 \mu \mathrm{L} / \mathrm{min}$. In opposite, when PU was chemically activated (PU_ChA), the immobilization process was stable in the entire assay. The increase of the PU-Au NPs (PU_U) frequency $(\sim 20 \mathrm{~Hz})$ can be related with the removal of gold nanoparticles (very small particles). The increase in the PU-Au NPsCM frequency $(200 \mathrm{~Hz})$ can be related to the removal of gold nanoparticles bound to $\mathrm{CM}$. This 
higher frequency shift suggests that the immobilized $\mathrm{CM}$ or even the immobilization process facilitates the release of the coating if PU was not activated.

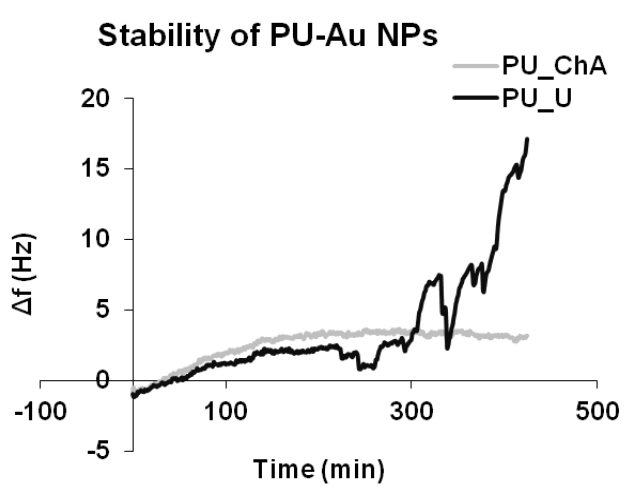

(A)

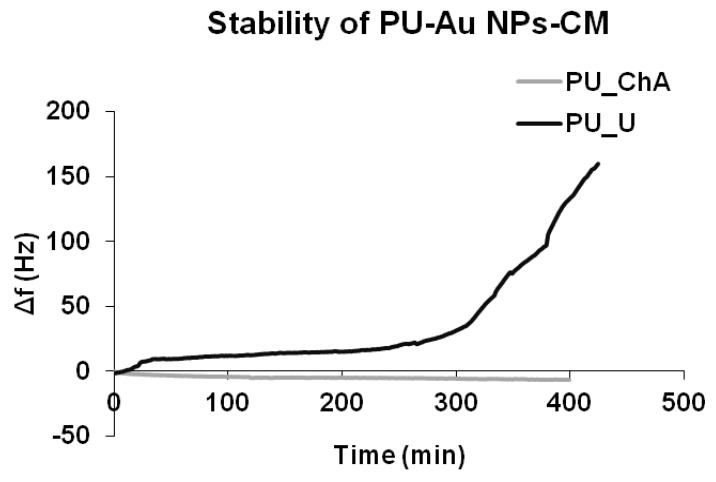

(B)

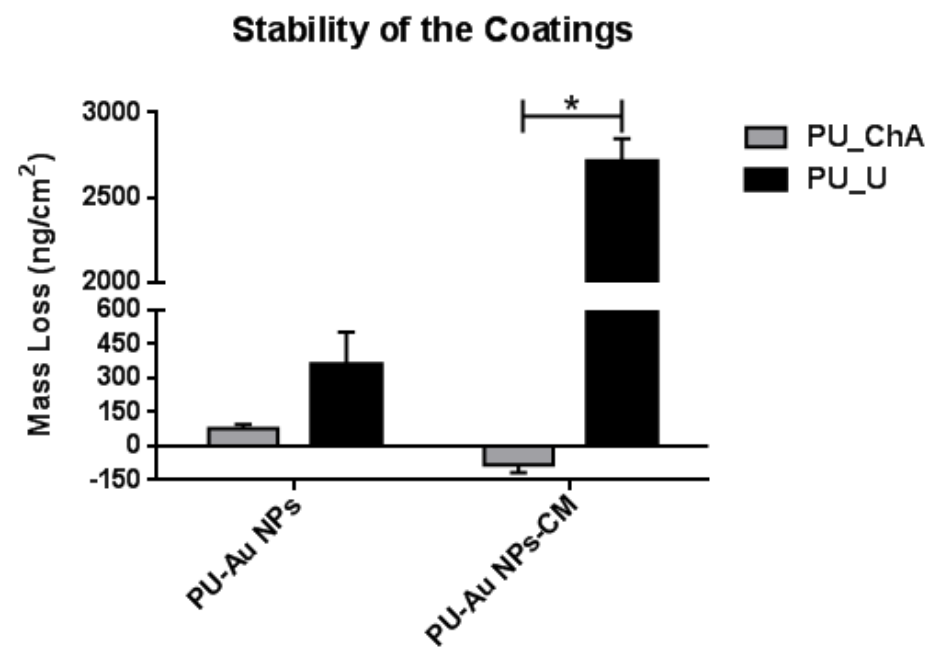

(C)

Figure 31- (A) PU-Au NPs and Pu-Au NPs-CM (B) stability profiles from $7 \mathrm{~h}$ injection of PBS at different speeds (from 12.5 to $200 \mu \mathrm{L} / \mathrm{min}$ ) in PU_ChA and PU_U . (C) Total mass changes registered on the surfaces in PU_ChA and PU_U. Positive values correspond to mass loss and negative values correspond to mass accumulation, on the sensor. Statistically significant differences are indicated with * $(p<0.05$, ANOVA).

Concerning PU_ChA, the small increase of the frequency $(\sim 3 \mathrm{~Hz})$ could be related with release of very few Au NPs. In contrast, the very small decrease in the PU-Au NPs-CM on PU_ChA can probably be explained by the adsorption of some salts from the buffer (PBS) at $37^{\circ} \mathrm{C}$. Still, in both cases the variations are too small to be considered, in view of the Au NPs and CM molecular weights of $16548 \mathrm{kDa}$ and $1874 \mathrm{kDa}$, respectively. Figure $31 \mathrm{C}$, which translates these shifts in frequency of vibration into mass changes using the Sauberbrey equation, shows exactly this. The mass variation is clearly very small, less than $100 \mathrm{ng} / \mathrm{cm}^{2}$, for the chemically modified surfaces (PU_ChA) and much higher for the unmodified (PU_U) $\sim 2800 \mathrm{ng} / \mathrm{cm}^{2}(p<0.05$, ANOVA). The results show the need of chemically treating the PU surface prior to the immobilization of both the Au NPs and the CM in order to acquire stable and functional coatings. This step made part of optimization of the immobilization process in 
PU and, after understand that without the PU pre-activation step the immobilization process was compromised, PU was always pre-activated according to previously described [196].

\subsubsection{Scanning Electron Microscopy (SEM)}

Figure 32 shows the evident differences in surface morphology of PU, PU-Au NPs and PUAu NPs-CM, obtained by SEM.

The PU coating exhibits a smooth morphology/topography. The addition of nanoparticles increased the roughness of the surface. Moreover, at higher magnification the distribution of Au NPs can be observed. The expected size of the Au NPs was $14 \mathrm{~nm}$, however, as we can see in Figure 32, the obtained value for Au NPs size was around $25 \mathrm{~nm}$, suggesting some particles aggregation. After CM immobilization, it is possible to distinguish the nanoparticles, smaller in size $(\sim 18 \mathrm{~nm})$ and more defined than on PU-AU NPs, which could be explained by the high affinity of the thiol group of the PEG-spacer to gold that could dissolve/remove some Au NPs aggregates [197]. Moreover, Au NPs immobilization was followed by 3 steps of chemical reactions and washing procedures, which can facilitate the dissolution of Au NPs aggregates.

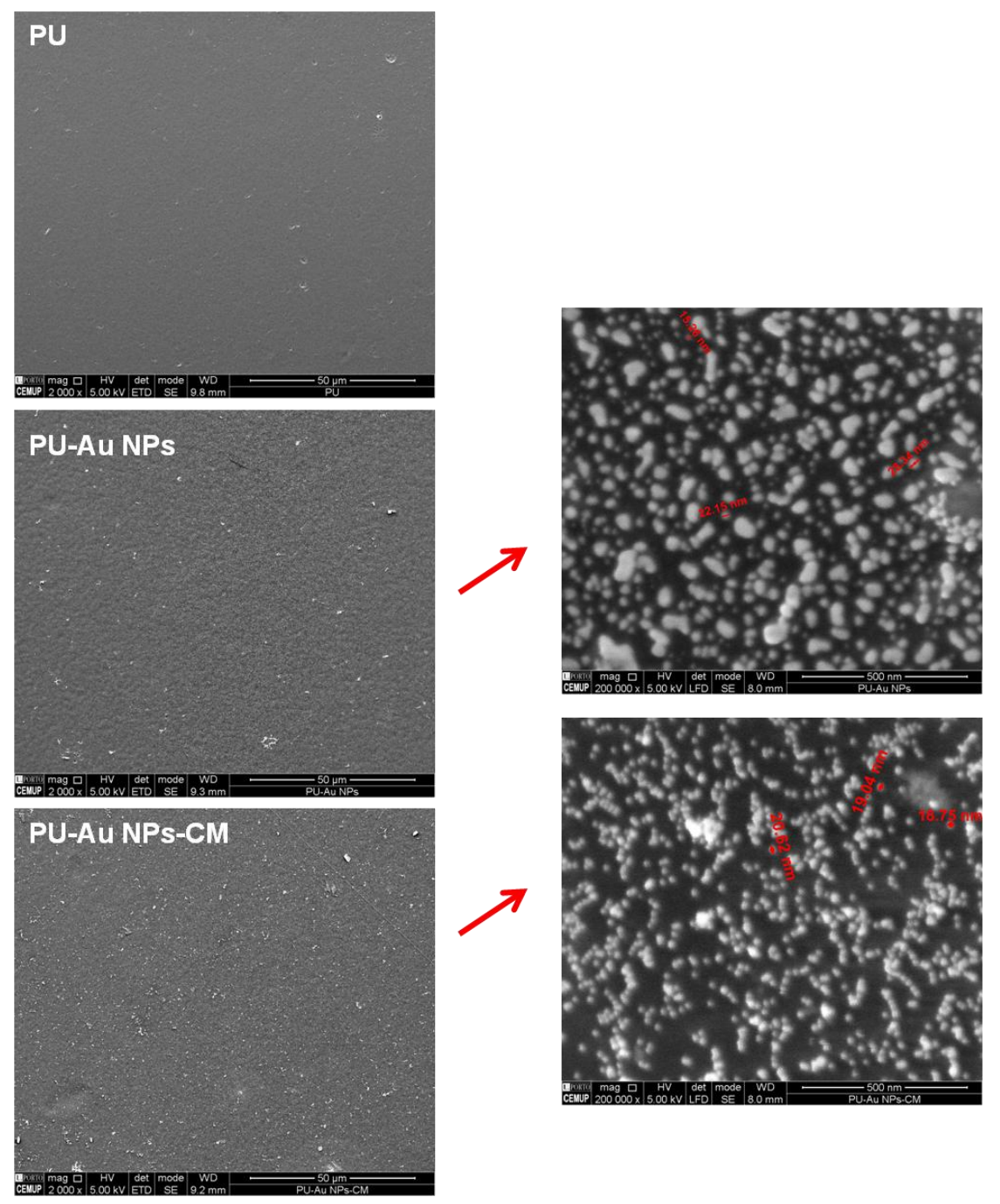

Figure 32- Surface morphology of PU, PU-Au NPs and PU-Au NPs-CM obtained by SEM at 2,000x and 200,000xmagnification. 


\subsubsection{Water Contact Angle}

In order to evaluate the wettability of the different surfaces, water contact angle measurements were conducted (Figure 33). PU showed a water contact angle of $80^{\circ}$, similar with previously reported [190]. Au NPs immobilization did not significantly change the water contact angle $\left(82^{\circ}\right)$, which can be related with the increase of surface roughness and the introduction of $\mathrm{CH} 3 / \mathrm{CH} 2$ groups from APMTS. However, $\mathrm{CM}$ immobilization decreased the water contact angle $\left(67^{\circ}\right)$ of the surface in a significant way $(p<0.05$, ANOVA). This increase of surface hydrophilicity can be related not only to $C M$ immobilization but also to the thiolPEG-NH $\mathrm{N}_{2}$ and thiol-PEG-COOH that was firstly immobilized onto Au NPs. This results are also consistent with previous published work[96].

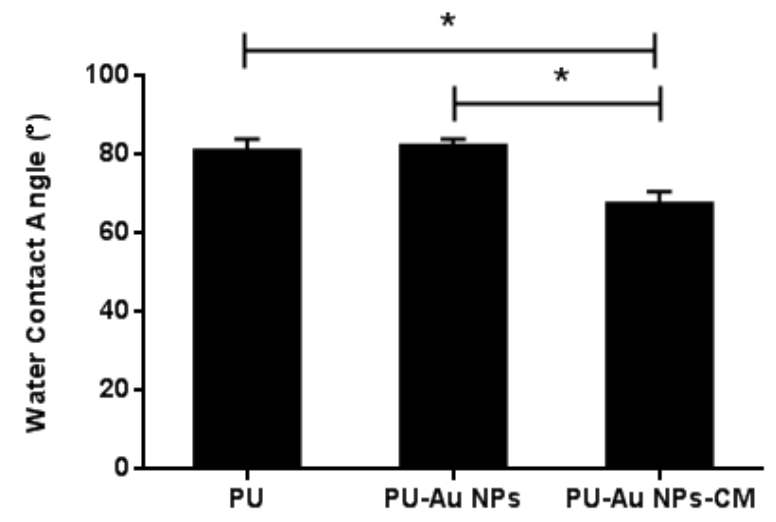

(A)
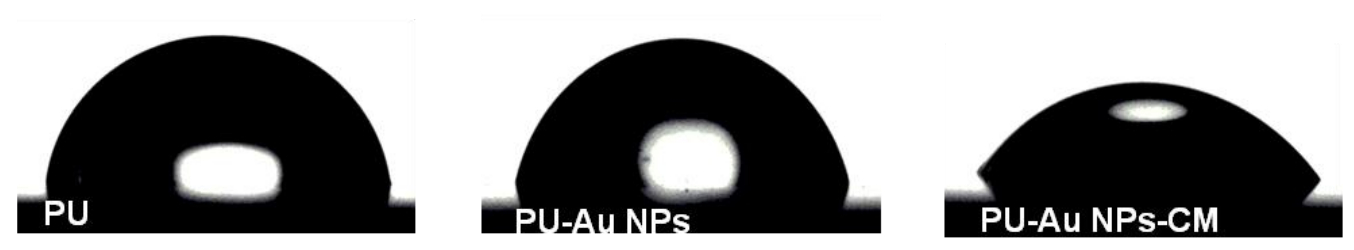

(B)

Figure 33- (A) Water optical contact angles of the surfaces PU, PU-Au NPs and PU-Au NPs-CM. (B) Appearance of water drop in contact with the each surface. Statistically significant differences are indicated with * $(p<0.05$, ANOVA $)$.

\subsubsection{Thickness of Coatings: Ellipsometry}

Ellipsometry was used to determine the thickness of the film after each immobilization process, since it is expected to detect an increase in the film thickness if immobilization occurs.

As explained in section 3.3, ellipsometry measures changes in the state of polarization of the light upon reflection from a surface. This technique can measure film thickness up to 100 $\mathrm{nm}$. It was not possible to measure the thickness of the films after $C M$ immobilization, due to dispersion of the light suggesting that film could have a thickness near $100 \mathrm{~nm}$. This way, thickness measurements were only performed on PU and PU-Au NPs surfaces.

Figure $34 \mathrm{~A}$ shows the average thickness of PU and PU-Au NPs surfaces. It was observed, that after Au NPs treatment the film thickness increased $\sim 23 \mathrm{~nm}(p<0.001, t$-test). This value 
is similar to the size of the nanoparticles $(-20-25 \mathrm{~nm})$, so this result confirms Au NPs immobilization on PU, with the increase on the thickness being caused by nanoparticles addition.

Figure $34 \mathrm{~B}$ shows the similarity between the images of gold substrates coated with $\mathrm{PU}$ and PU-Au NPs, displayed during thickness measurements. PU-Au NPs presents some small particles that could be related with the surface immobilization process.

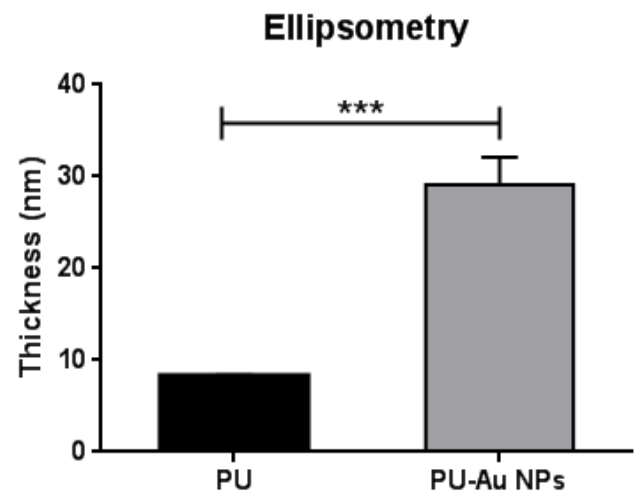

(A)

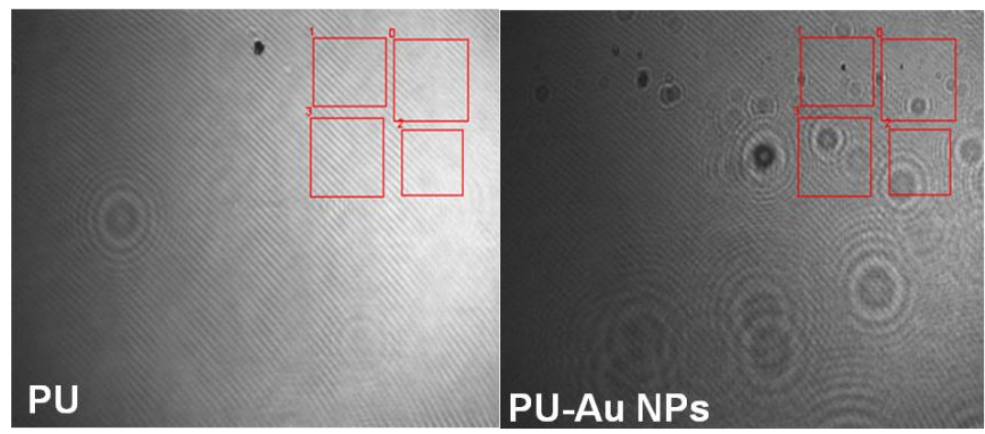

(B)

Figure 34 - (A) Results from ellipsometry on PU and PU-Au NPs. Statistically significant differences are indicated with ${ }^{* * *}(\mathrm{p}<0.001)$. (B) Aspect of the surfaces during ellipsometry assay.

\subsubsection{X-ray Photoelectron Spectroscopy (XPS)}

Atomic composition of the surfaces, PU, PU-Au NPs and PU-Au NPs-CM, determined using XPS is described in Table 2. The elements analyzed were Carbon (C), Nitrogen (N), Oxygen $(\mathrm{O})$, Sulfur (S), Silicon ( $\mathrm{Si})$ and Gold $(\mathrm{Au})$. Results demonstrated that no elements other than those expected were found, indicating that no contamination took place.

The atomic composition of the PU revealed a high percentage of Carbon and Oxygen and a lower \% of Nitrogen, as previously described [198] [190].

After coating with Au NPs, surface presented silicon and gold, as expected from PU coating with $\mathrm{SiCL}_{4}$, APTMS (3-amino propyltrimethoxysilane) and from the Gold nanoparticles respectively (Table 2). In Table 3, it is possible to see the different Carbon e Sulfur bonds obtained by high-resolution XPS spectra. After Au NPs addition there is an increase of C1s with binding energies at $285 \mathrm{eV}$ and $288 \mathrm{eV}$. The peak at $285 \mathrm{eV}$ can be assigned to $\underline{\mathrm{CH}}_{2} / \underline{\mathrm{C}} \mathrm{H}_{3}$ 
groups and the peak at $288 \mathrm{eV}$ to $-\mathrm{O}-\underline{\mathrm{C}}-\mathrm{O}-$-, both present in APTMS. In addition, the decrease of carbon at $285.6 \mathrm{eV}(\mathrm{C}-\mathrm{O}-\mathrm{C})$ from the PU composition also indicates that the PU was covered with other compounds, namely APTMS and Au NPs.

After spacer (HS-PEG-NH ${ }_{2}$ and HS-PEG-COOH) and cysteine-CM (HS-CM) immobilization, there is the appearance of Sulfur and an increase of Nitrogen and Carbon (Table 2). These elements are part of the spacer and peptide composition and their increase demonstrate the success of the spacer and CM immobilization. In addition, there was a decrease on Gold relative percentage after $\mathrm{CM}$ immobilization and Silicon was not detected. This could be related with Silicon deeper location. Table 3 shows the increase of carbon at $286 \mathrm{eV}$, assigned to a Carbon bond to one Oxygen, indicating the presence of PEG - $\left(\mathrm{CH}_{2}-\mathrm{CH}_{2}-\mathrm{O}\right)_{n}$ - and, the increase of carbon at $288 \mathrm{eV}$, which is associated with the presence of the spacer $(\mathrm{COOH}$ PEG) and the peptide ( $-\mathrm{N}-\underline{\mathrm{C}}=0$; from the peptide bond). In addition, the presence of $\mathrm{S} 2 \mathrm{p}$ at $162 \mathrm{eV}$ indicates thiol-PEG-spacers bonded to Au NPs (S-Au) and S2p at $164 \mathrm{eV}$ can be related to the thioether group ( $\mathrm{S}-\mathrm{C})$ formed by the link between the HS-CM and the maleimide group (from the sulfo-GMBS). These results can confirm the success of CM covalent immobilization.

Table 2- Surface atomic composition (\%) of the different samples calculated from highresolution XPS spectra.

\begin{tabular}{ccccccc}
\cline { 2 - 7 } & \multicolumn{7}{c}{ Atomic Percentage (\%) } \\
\cline { 2 - 7 } & C1s & N1s & 01s & S2p & Si2p & Au4f \\
\hline PU & 79 & 3 & 18 & 0 & 0 & 0 \\
PU-Au NPs & 59 & 2 & 17 & 0 & 14 & 7 \\
PU-Au NPs-CM & 71 & 6 & 16 & 1 & 0 & 6 \\
\hline
\end{tabular}

Table 3- Surface composition (\%) of Carbon and Sulfur calculated from high-resolution XPS

\begin{tabular}{|c|c|c|c|c|c|}
\hline \multirow{3}{*}{$\mathrm{BE}(\mathrm{eV})$} & \multicolumn{3}{|c|}{$\%$ C1s } & \multicolumn{2}{|c|}{$\%$ S2p } \\
\hline & 285.0 & 286.5 & 288.0 & 162.0 & 164.0 \\
\hline & $\mathrm{C}-\mathrm{C} ; \mathrm{C}-\mathrm{H}$ & $\begin{array}{c}\mathrm{C}-\mathrm{NH}_{2} ; \mathrm{C}-\mathrm{OH} ; \\
\mathrm{C}-\mathrm{O}-\mathrm{C}\end{array}$ & $\begin{array}{l}\mathrm{O}-\mathrm{C}-\mathrm{O} \\
\mathrm{N}-\mathrm{C}=\mathrm{O}\end{array}$ & $\mathrm{S}-\mathrm{Au}$ & S-C \\
\hline PU & 63 & 35 & 2 & 0 & 0 \\
\hline PU-Au NPs & 71 & 24 & 5 & 0 & 0 \\
\hline PU-Au NPs-CM & 52 & 41 & 7 & 34 & 66 \\
\hline
\end{tabular}




\subsubsection{Fourier Transformed Infrared - Attenuated Total Reflectance (ATR- FTIR)}

To evaluate eventual modification in chemical bonds on the different surfaces, with peptide addition, ATR-FTIR was performed (Figure 35).

FTIR spectra of PU films demonstrated PU characteristic absorption bands, namely the absorption bands at $1595 \mathrm{~cm}^{-1}$ and $1413 \mathrm{~cm}^{-1}$ from benzene ring and at $1528 \mathrm{~cm}^{-1}$ from N-H and C-N from the urethane group [199] [190]. After nanoparticles and peptide addition it was expected to observe some modification on the characteristic absorption bands of the proteins/peptides: Amide I $(C=0)$ at $1690 \mathrm{~cm}^{-1}$ and Amide II $(C-N)$ at $1540 \mathrm{~cm}^{-1}$. However, such changes were not detected [200].

Since Au NPS and CM immobilization was no detected by this technique but was detected by others (such as XPS and spectroscopy), we believe that surface immobilization occurred at a very superficial layer in the PU film. This can be explained since this technique has a depth of penetration in the order of micrometers [184], and the Au NPs and CM layers are in the order of nanometers. This way, the equipment detect a big amount of the bulk (PU), losing some sensitivity for more superficial layers (Au NPs and CM), causing PU-Au NPs and PU-Au NPs-CM surfaces to present the same spectra as PU.

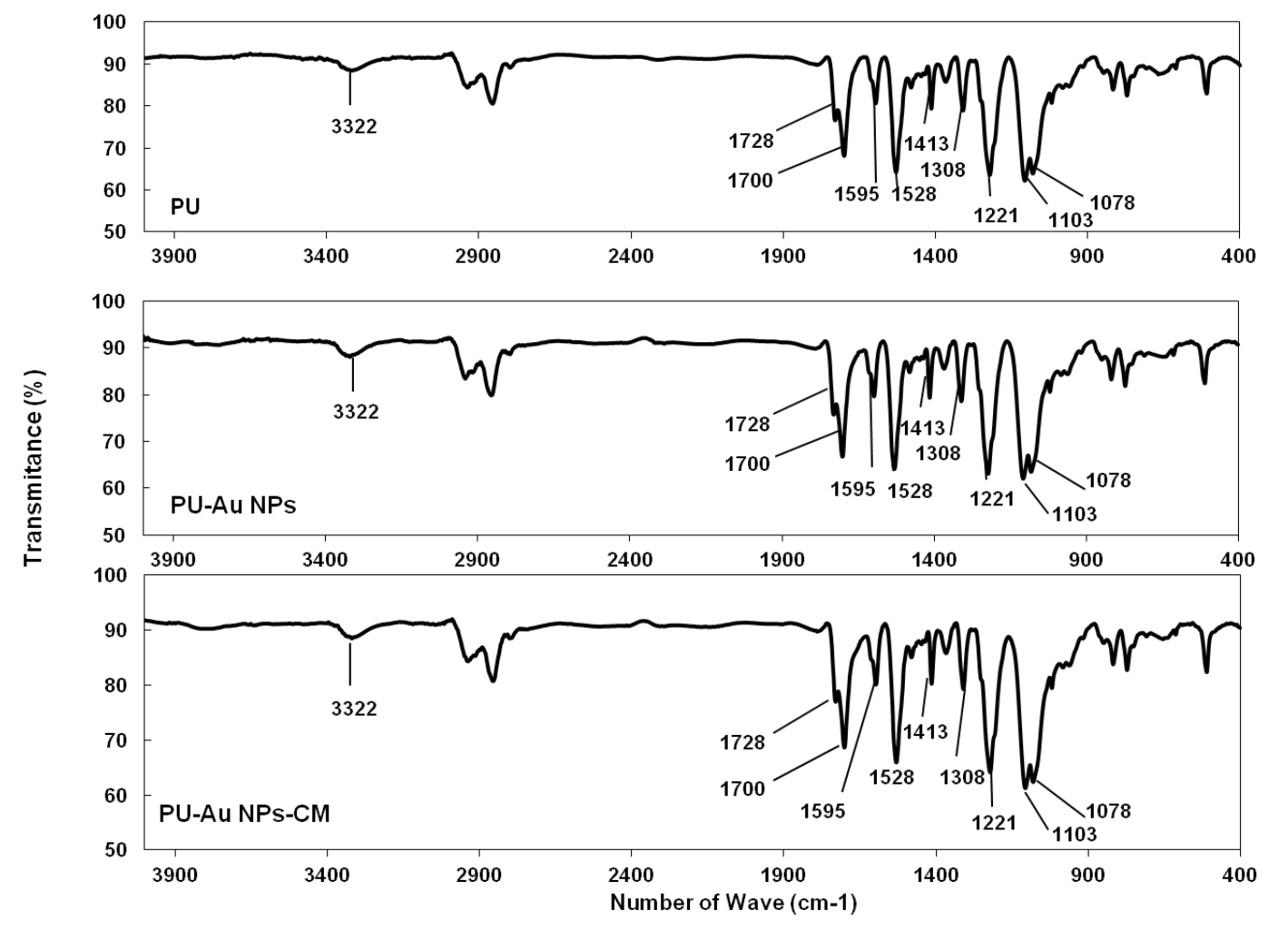

Figure 35- FTIR-ATR spectra of PU, PU-Au NPs and PU-Au NPs-CM.

\subsubsection{Immobilized CM quantification}

Results from spectroscopy analysis demonstrated that CM was successfully immobilized on Au NPs-coated surfaces in a concentration of $68 \mathrm{\mu g} / \mathrm{cm}^{2}$. 


\subsection{Biological Testing}

\subsubsection{Protein Adsorption}

Using QCM-D, the adsorption of human plasma proteins on PU, Au NPs and CM coated surfaces was investigated using human plasma at $1 \%$ in PBS and a flow rate of $25 \mu \mathrm{L} / \mathrm{min}$ $\left(37^{\circ} \mathrm{C}\right)$.

Figure $36(A, B, C)$ shows the protein adsorption profiles on the three surfaces. It was observed that plasma proteins rapidly adsorbs to all the surfaces tested. In all the samples there is a decrease on the frequency of sensor vibration until a plateau was reached. On PU samples, the frequency decreased up to around $60 \mathrm{~Hz}$, on PU-Au NPs until approximately 52 $\mathrm{Hz}$ and on $\mathrm{CM}$ coated surfaces until $38 \mathrm{~Hz}$. The time to reach the plateau (saturation), moment in which there are no more active sites on the surface for protein binding, was different between surfaces. For instance, PU, which experienced a superior frequency shift, took less time to reach saturation than the PU-Au NPs and especially the PU-Au NPs-CM surfaces, which frequency shift was smaller.

Differences on the kinetics of protein adsorption are related with the type of surface, namely its wettability and if they have affinity to certain proteins that adsorbs faster, particularly albumin. This protein is always the first protein to contact with surfaces due to its higher concentration in plasma $(40 \mathrm{mg} / \mathrm{mL})$ and their small size $(M W=66 \mathrm{kDa})$ and higher diffusion coefficient (DC) $\left(6.1 \times 10^{-7} \mathrm{~cm}^{2} / \mathrm{s}\right)$. However, depending of the surface, adsorbed albumin can be exchanged by other plasma proteins that exist in lower concentration and are usually larger in size (immunoglobulins with concentrations $\sim 15 \mathrm{mg} / \mathrm{mL} ; M W=150 \mathrm{kDa}$ and $D C=4 \times 10^{-7} \mathrm{~cm}^{2} / \mathrm{s}$; fibrinogen with concentrations $\sim 3 \mathrm{mg} / \mathrm{mL} ; M W=340 \mathrm{kDa}$ and $D C=2 \times 10^{-7}$ $\mathrm{cm}^{2} / \mathrm{s}$, etc) [49]. This process is known as Vroman effect [3]. However, QCM-D can only distinguish the type of adsorbed protein using specific antibodies against each suspected adsorbed protein, which could be a complicated and expensive process [201]. In general, hydrophobic surfaces adsorb more proteins in a faster and irreversibly way.

Figure $36 \mathrm{D}$ shows the total amount of protein adsorbed on the three surfaces. The amount of plasma proteins adsorbed on PU and Au NPs was similar and higher than on CM-coated PU $(p<0.0001$, ANOVA). This could be related with their similar and higher hydrophobicity (water contact angle $\sim 80^{\circ}$ ). It has been shown that the hydrophobic character of surfaces increases the adsorption of proteins since hydrophobic surfaces allow interaction with hydrophobic domains and residues in the protein [202].

The lower protein adsorption on CM-coated PU is a quite positive outcome, as some adsorbed proteins may induce bacterial adhesion, coagulation/complement activation and platelet adhesion/activation. This lower protein adsorption on CM-coated PU can be related with i) surface immobilization of a non-fouling polymer (PEG-spacer) and/or ii) creation of a zwitterionic surface (surface with negative and positive charged groups) that was obtained by the combination of $\mathrm{COOH}$-PEG spacer with a cationic peptide (CM rich in arginine amino acids: KWKLFKKIGAVLKVLC). This antifouling ability of hydrophilic and zwitterionic surfaces is correlated with a hydration layer near the surface. This tightly bound water layer forms a physical and energetic barrier to prevent protein adsorption on the surface. Removal of water molecules from the surface, is the first and obligatory step to facilitate protein adsorption by 
reducing free energy barrier arising from dehydration entropic effects. If the water layer cannot be removed protein adsorption will be limited [203] [204].

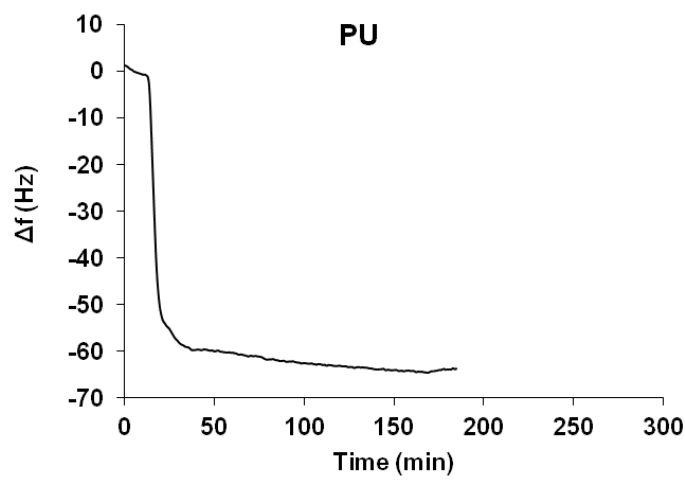

(A)

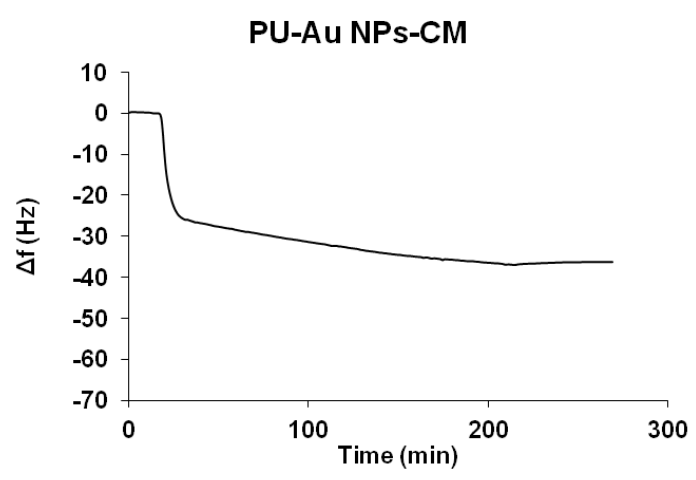

(C)

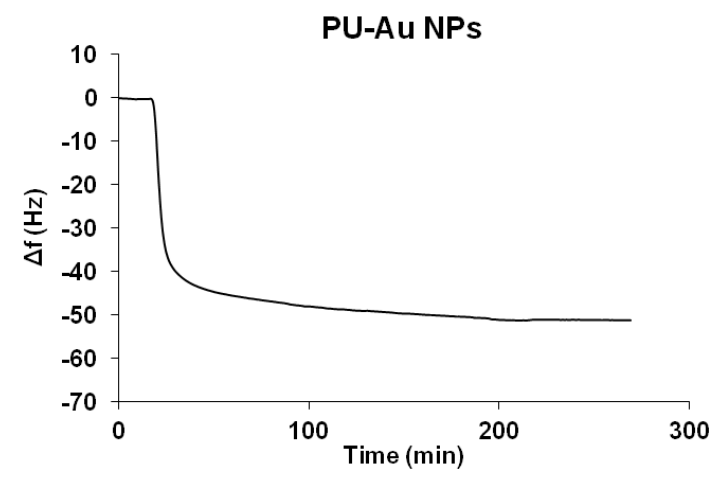

(B)

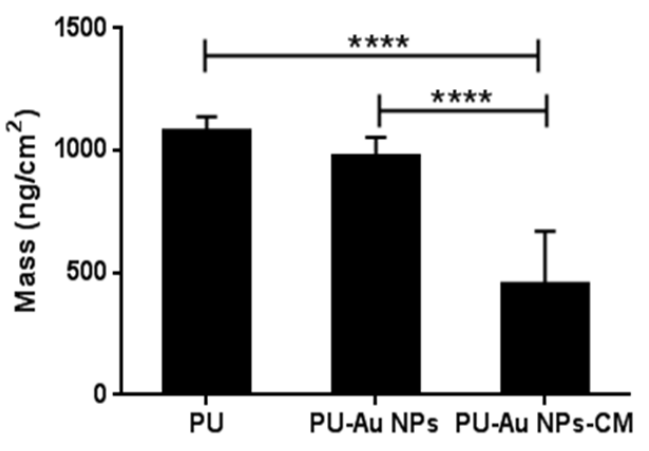

(D)

Figure 36- $(A, B, C)$ QCM-D protein adsorption profiles from $1 \%$ human plasma in PBS on PU, Au NPs and $C M$. (D)Total amount of proteins adsorbed from 1\% human plasma in PBS on PU, Au NPs and CM.

Statistically significant differences are indicated with ${ }^{* * *}(p<0.0001)$.

\subsubsection{Platelet Adhesion and Activation}

Figure 37 demonstrated that $C M$ coating (PU-Au NPs-CM) significantly decrease platelet adhesion to PU, independently of the media used, PBS ( $<<0.001$, ANOVA) or $1 \%$ human plasma $(p<0.05, A N O V A)$. This result suggests that $C M$ coating may provide anti-adhesive properties to the surface, possibly due to its hydrophilic characteristics and low protein adsorption. These results are consistent with a work previously published, in which more hydrophobic surfaces presented a higher number of adhered platelets, comparing to more hydrophilic surfaces [54].

Pre-immersion in human plasma slightly increased the number of adhered platelets to $\mathrm{CM}$ coated PU comparing to pre-immersion in PBS, although these differences are not statistically significant (Figure 37). Although it was demonstrated that PU surface adsorbs more plasma proteins than PU-Au NPs-CM (Figure 36), pre-adsorption in human plasma did not affect platelet adhesion to PU. This could be explained by the elevated number of platelets that were able to adherent to the hydrophobic PU surface in PBS.

Concerning platelet activation, Figure 38 shows that $\mathrm{CM}$ immobilization did not induce platelet activation in comparison with PU surface independently of the presence (Figure 38B) 
of pre-adsorbed plasma proteins ( $1 \%$ human plasma) (Figure 38A). This results are quite positive since it is not only important to decrease platelet adhesion to the catheters surface but also to avoid its activation because activated platelet are more likely to induce thrombus formation. In addition, it was also demonstrated that adsorbed plasma proteins decrease platelet activation in both surfaces, suggesting that the adsorbed protein layer is not composed with fibrinogen, vitronectin or von Willebrand factor, the proteins that, after adsorption to a surface, are responsible for platelet adhesion/activation [54]. These are very promising results since intravascular catheters will be always in direct contact with blood and therefore in contact with plasma proteins.

Representative images of platelets adhesion and activation in contact with each surface can be observed in Figure 39.

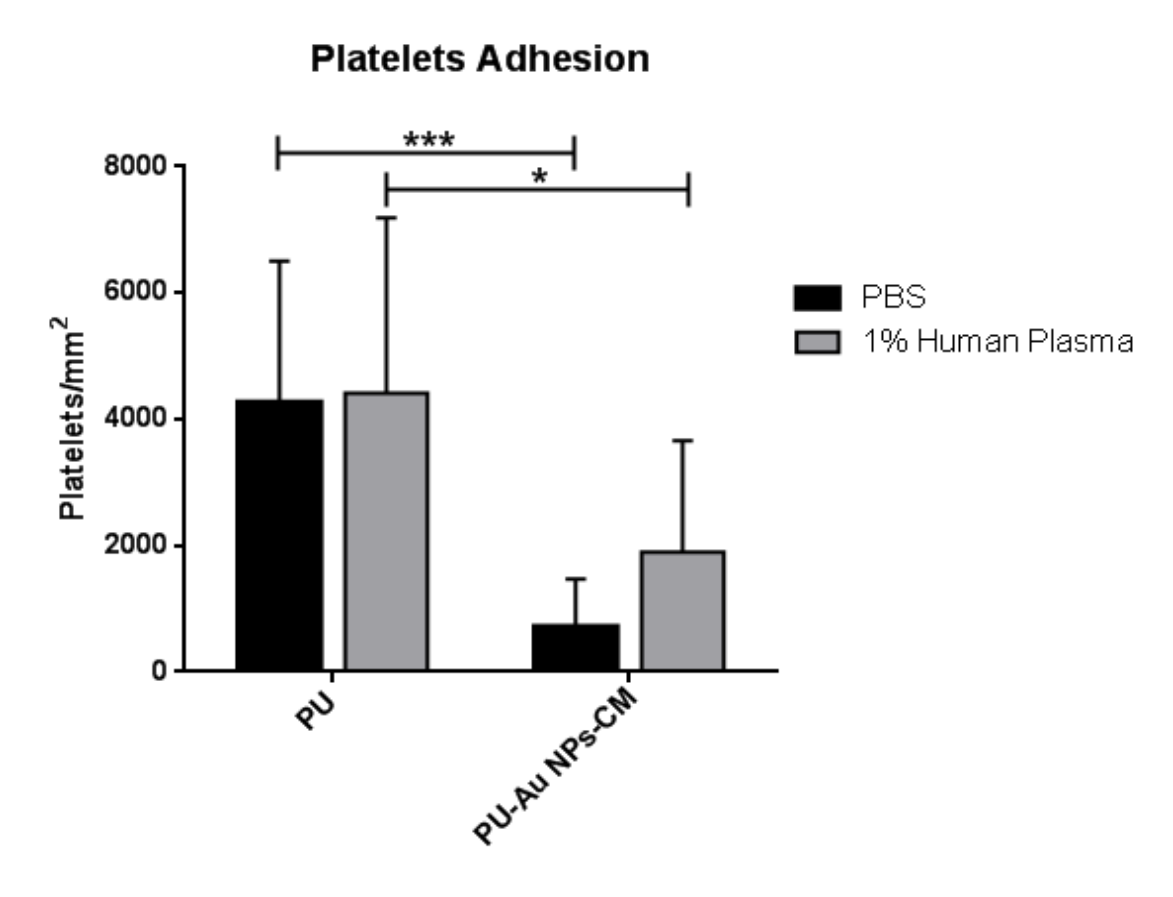

Figure 37 - Adhesion of human platelets on PU, PU-Au NPs and PU-Au NPs-CM. Surfaces were preimmersed in PBS or $1 \%$ human plasma. Statistically significant differences are indicated with * $(p<0.05)$ and ${ }^{* * *}(p<0.001)$.

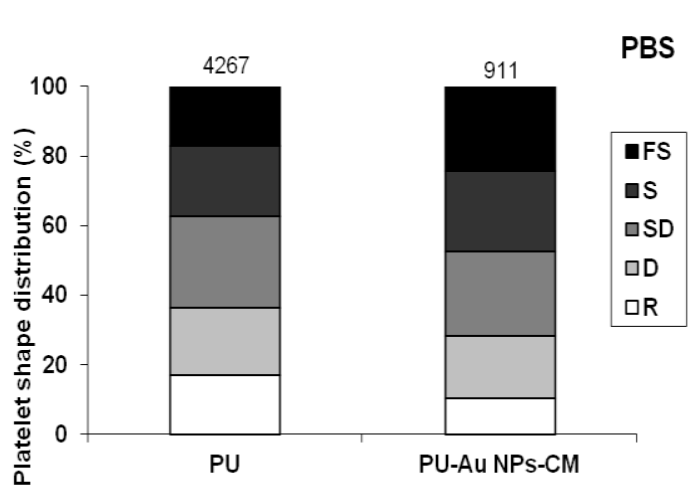

(A)

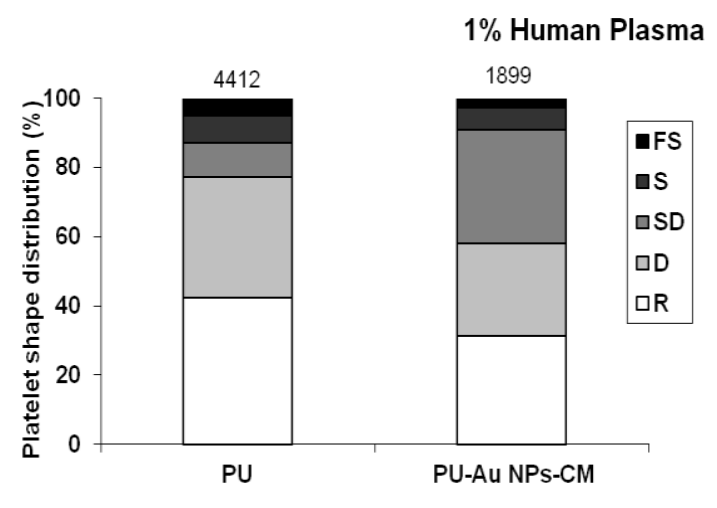

(B)

Figure 38 - Platelet shape distribution on PU, PU-Au NPs and PU-Au NPs-CM. Surfaces were pre immersed in PBS $(A)$ or $1 \%$ human plasma $(B)$. 

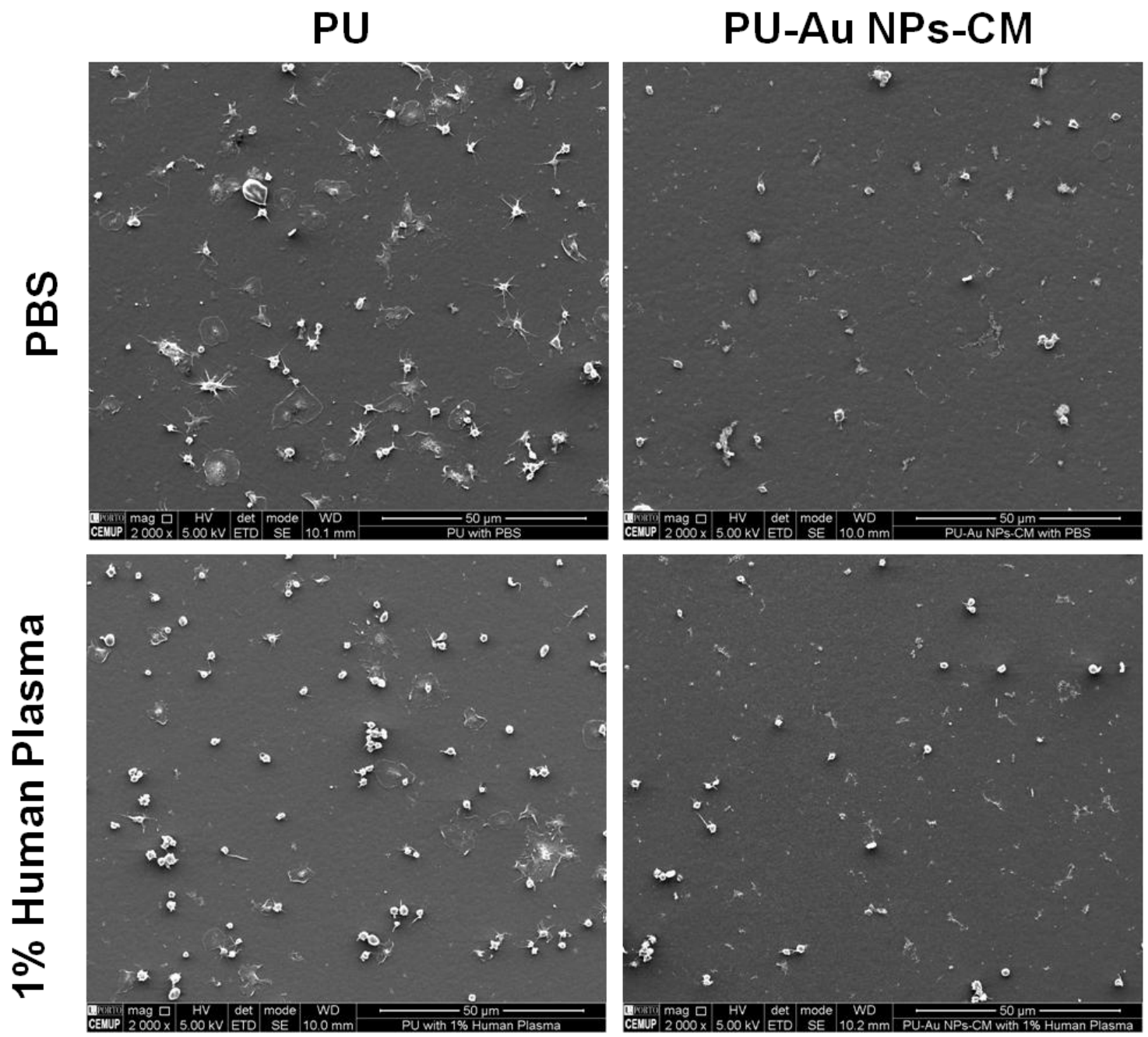

Figure 39- Representative images of platelets adhesion and activation in contact with PU and PU-Au NPCM surfaces in the presence of PBS and 1\% human plasma. Images were obtained by SEM at 2,000x magnification.

\subsubsection{Bacterial Adhesion to $\mathrm{CM}$ coating}

Bacteria adhesion assays demonstrated that $C M$ immobilization decreases bacteria adhesion to PU when surface are pre-immersed in PBS ( $p<0.05$, ANOVA) (Figure 40). These results suggest that $C M$ immobilization provide anti-adhesive properties to $P U$, as verified on platelets assays. This anti-adhesive property of $\mathrm{CM}$-coated PU may be related to its more hydrophilic character as explained before. However, in the presence of plasma proteins, there are no significant differences among PU and PU-Au NPs-CM surfaces. The decrease on bacteria adhesion to PU after plasma incubation, suggests that the adsorbed protein layer is mostly composed by albumin known as an anti-bacterial adhesion agent [205]. However, since this albumin "passivant" effect was not observed on platelet adhesion (Figure 37), more assays must be conducted to clarify the composition of the adsorbed protein layer, namely the type and conformation of adsorbed proteins.

Representative images can be observed in Figure 41. 


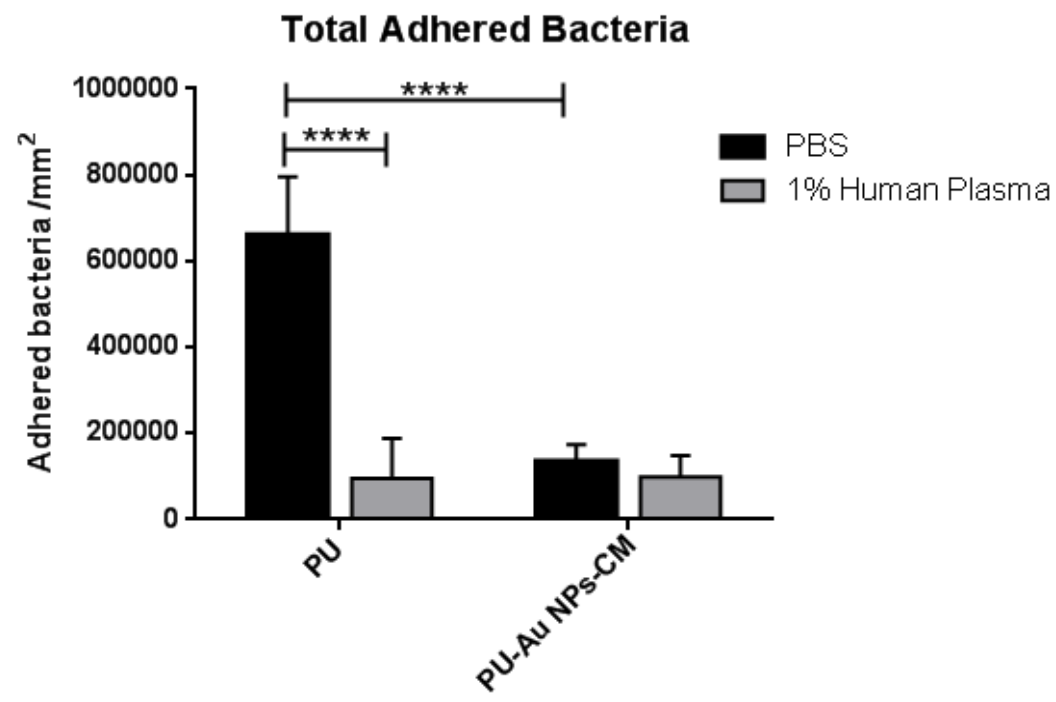

Figure 40- Total number of adherent bacteria on PU, PU-Au NPS and PU-Au NPs-CM. Statistically significant differences are indicated with ${ }^{* * * *}(p<0.0001)$.

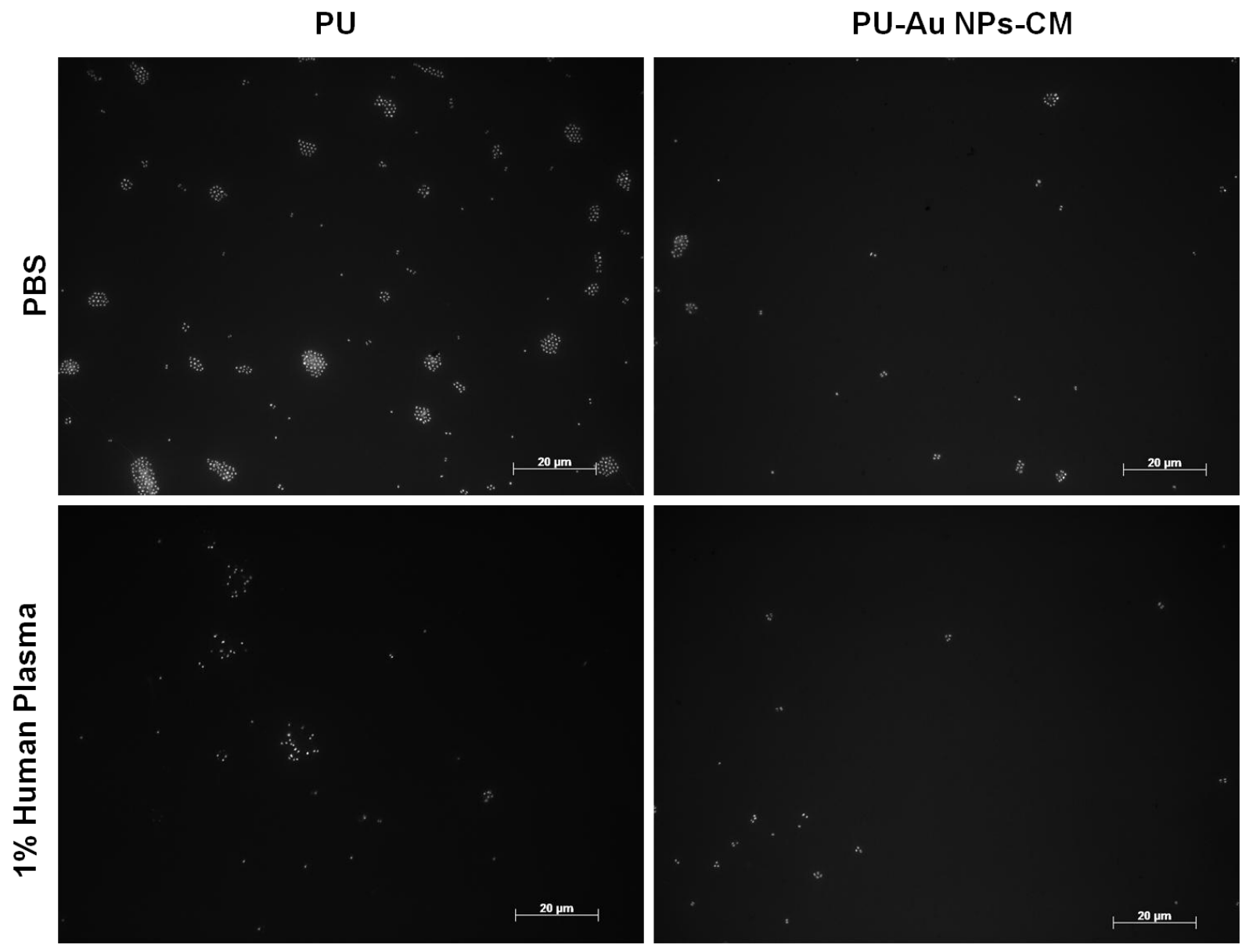

Figure 41- Representative images of bacteria adhesion to PU and PU-Au NP-CM surfaces in the presence of PBS and $1 \%$ human plasma. Images were obtained by MIF at 100x with oil, $20 \mu \mathrm{m}$ scale. 


\subsubsection{Viability of adherent bacteria}

Concerning bacteria viability, Figure 42 shows that all bacteria adherent to $\mathrm{CM}$-coated PU are dead, contrary to PU surfaces where more than $50 \%$ of adherent bacteria are alive. These results are consistet with a previous work where the high antimicrobial activity of $C M$ was verified, although immobilized in a different surface [206].

The presence of plasma proteins did not compromise the antibacterial effect of $\mathrm{CM}$, since the number of dead bacteria is similar to the number of total adhered bacteria, suggesting that this surface is able to kill adherent bacteria by contact, even in the presence of human plasma. These results are quite promising since our CM coating seems to have not antiadhesive properties but also antimicrobial activity. This way, it may be able to decrease bacterial adhesion to catheters and also to kill the few bacteria that still can adhere to the device.
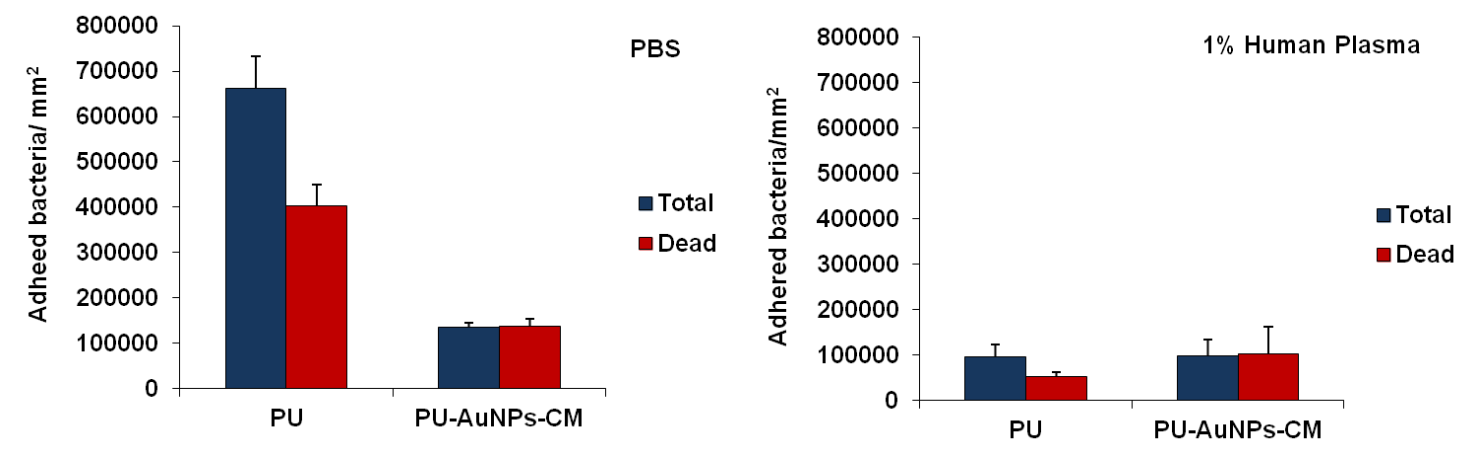

Figure 42- Comparison between total and dead adhered bacteria.

\section{3 MSI-78 (1-17) and MSI-78 (2-18) Antimicrobial Activity}

\subsubsection{Antimicrobial activity assay}

Antimicrobial activity of PU films containing MSI-78-derived peptides, Figure 43 demonstrated that both peptides, MSI-78 (1-17) and MSI-78 (2-18), are able to kill S. epidermidis in a concentration dependent way. The antibiotic used as a second control, vancomycin, presented some antibacterial activity comparing to the main control, PU. However, PU films with AMPs presented higher antibacterial activity than PU with vancomycin.

When efficacy assays were performed in PBS, the decrease in CFUs due to the incorporation of AMPs on PU was statically significant ( $p<0.05$, ANOVA) for MSI-78 (1-17) with concentration 64 and $128 \mu \mathrm{g} / \mathrm{mL}$ and for MSI-78 (2-18) with all concentrations tested (Figure $42 \mathrm{~A})$. However, when efficacy studies were performed with bacteria suspended in human plasma, the antimicrobial effect of both peptides decrease although there are still 
statistically significant differences for MSI-78 (1-17) with $128 \mu \mathrm{g} / \mathrm{mL}$ concentration and for MSI-78 (2-18) with all concentration used.

PBS

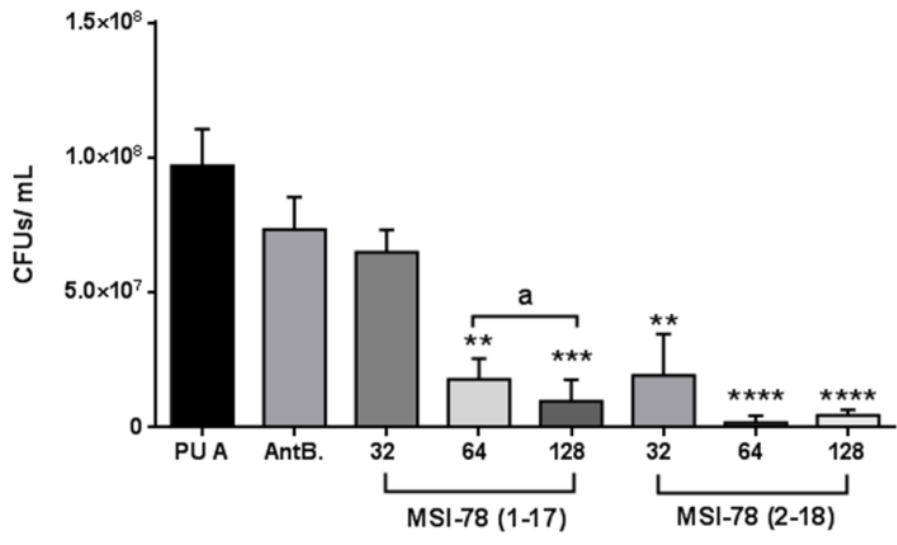

(A)
$1 \%$ Human Plasma

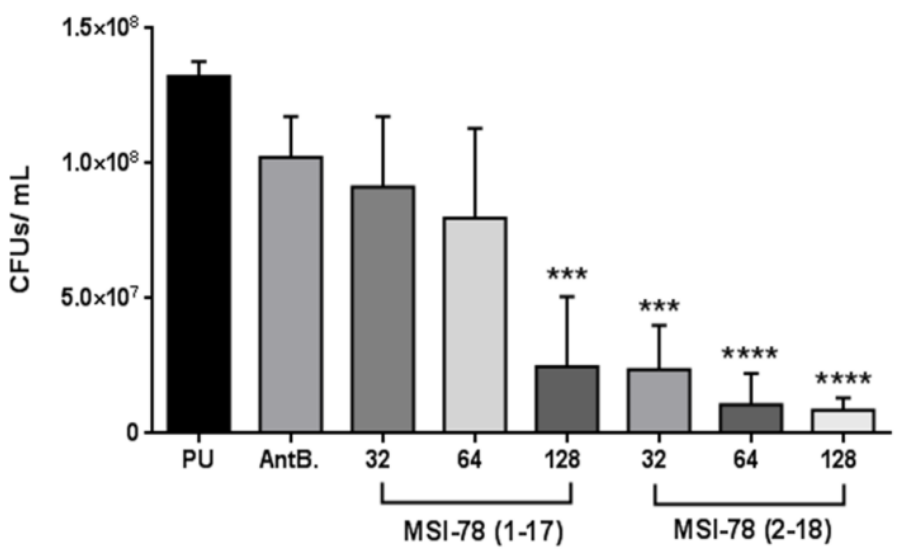

(B)

Figure 43- Number of CFUs after contact with the surfaces (bacteria solution in PBS) (A). Number of CFUs after contact with the surfaces (bacteria solution in $1 \%$ human plasma) (B). Statistically significant differences, comparing to the control (PU), are indicated with ${ }^{* *}(p<0.01),{ }^{* * *}(p<0.001),{ }^{* * * *}(p<0.0001)$. Statistically significant differences, comparing to lower peptide concentrations $(32 \mu \mathrm{g} / \mathrm{mL})$ are indicated with ' $a$ '.

Between different concentrations of the same peptide there was no statistic difference for MSI-78 (1-17) neither for MSI-78 (2-18).

The results suggests that both PU-MSI-78 (1-17) and PU-MSI-78 (2-18) have antibacterial activity, however, while PU-MSI-78 (1-17) only demonstrates activity in high concentrations (64 and $128 \mu \mathrm{g} / \mathrm{mL}$ in PBS and $128 \mu \mathrm{g} / \mathrm{mL}$ in 1\% human plasma), MSI-78 (2-18) presents activity even in low concentration $(32 \mu \mathrm{g} / \mathrm{mL})$ both in PBS and $1 \%$ human plasma presence. These results are different from expected, since in solution MSI-78 (1-17) presented a higher antimicrobial activity against S. epidermidis (Minimal Inhibitory Concentration- MIC $=4-8$ $\mu \mathrm{g} / \mathrm{mL})$ comparing to MSI-78 $(2-18)(M I C=16-32 \mu \mathrm{g} / \mathrm{mL})$ [4]. The differences in our results could be related with different peptides release profile from the PU. It could be possible that although very similar in composition, with only one different aminoacid (GIGKFLKKAKKFGKAFV for MSI-78 (1-17) and IGKFLKKAKKFGKAFVK for MSI-78 (2-18)), MSI-78 (2-18) releases more easily from the PU comparing to MSI-78 (1-17).

To evaluate MSI-78 release kinetics from PU, both peptides will be synthesized with a fluorescent label to follow its release, both in PBS and in human plasma, to clarify if the differences on their antimicrobial properties can become from different release characteristics. 


\section{Chapter 6}

\section{Conclusions and Future Perspectives}

The aim of this research work was the development of PU coatings with antimicrobial activity against bacteria, namely S. epidermidis without inducing thrombus formation, namely platelet adhesion and activation.

During the first part of the work, the AMP cecropin-melittin (CM) was successfully covalently immobilized onto PU films, using several chemical sequential steps that goes briefly from the activation of PU films, the binding of gold nanoparticles (Au NPs) and finally the CM coupling. Since PU was not easy to modify chemically, its pre-activation with $\mathrm{SiCl} 4$ was essential for the stability of the coating in flow conditions as demonstrated by us, using QCM-D. Surface characterization techniques also proved that $C M$ was successfully immobilized. SEM showed an increase of the roughness of PU due to the presence of Au NPS and CM immobilization. Au NPs with $\sim 25 \mathrm{~nm}$ can be observed using this technique, however with $C M$ addition, the nanoparticles seem a bit smaller $\sim 20 \mathrm{~nm}$. Surface wettability was also modified after peptide immobilization, with a decrease of the water contact angle on the surface, proving once more the peptide presence. Ellipsometry showed an increase in surface thickness with AU NPs immobilization proving their presence, however, this technique did not allow us to see the thickness increase with $C M$ immobilization, probably due to the high thickness increase with CM addition, exceeding the equipment analysis capacity (100nm). XPS results were also consistent with other characterization techniques, showing an increase on Au percentage with Au NPs immobilization. After peptide addition, an increase on the relative atomic percentage of Sulphur, Nitrogen and Carbon was observed. This was expected since these elements are part of peptide composition (Nitrogen and Carbon from all amino acids and Sulfur from the cysteine). Moreover, Sulphur can also be from the spacer used (thiolPEG) in immobilization process, and its increase suggests spacer and $C M$ efficient 
immobilization. ATR-FTIR was also performed on the samples, but no differences were observed between them. However, the depth of analysis of this technique is in the order of micrometers, decreasing its sensitivity for alterations on the first surface layers of the samples. These results suggest that this immobilization process occurred on the first surface layers of PU films.

It was also demonstrated that CM coating decreased the kinetic and the amount of plasma proteins adsorption on PU. These results are quite positive since avoiding protein adsorption on the surface could prevent future bacteria or platelets adhesion and activation. Tests with total blood would be enriching for this study. Moreover, it will be very important to evaluate which plasma proteins adsorb preferentially on CM coating, namely albumin, fibrinogen and other proteins involved in contact and complement activation.

CM-coated surfaces also showed a decrease in platelets adhesion, possibly because the higher hydrophilicity of these surfaces compared to PU. In the presence of plasma proteins, this tendency was maintained although the number of adherent platelets on CM-surface has duplicated. Nevertheless, adherent platelets in the presence of plasma proteins are in a lower state of activation suggesting that adsorbed plasma proteins may avoid platelet activation and thus prevent thrombus formation. However, more studies need to be done in the future to completely evaluate the hemocompatibility of this $\mathrm{CM}$-coating, namely coagulation and complement activation and leukocyte adhesion and activation.

Antibacterial efficacy studies showed a decrease on S. epidermidis adhesion to CM-coated surface, proving that this surface have anti-adhesive properties. Viability tests proved that bacteria adherent to $\mathrm{CM}$-coated surfaces are dead, suggesting that immobilized CM can kill bacteria by contact even in the presence of plasma proteins In the future, it would be important to evaluate the mechanism of action of the immobilized CM namely if after killing by contact, namely if bacteria membrane was destroyed and if dead bacteria were released from the surface. Moreover, biofilm formation was not tested during this work, but the understanding of the effect of the immobilized $\mathrm{CM}$ on biofilm production is essential. Off course that in the future it would be also very important to test other bacteria involved in catheter-related infections.

During the second part of this research work, the MSI-78 (1-17) and MSI-78 (2-18) peptides were incorporated on PU films and their bactericidal effect was also evaluated using $S$. epidermidis. This part of the work is still in a very initial phase, so surface characterization and AMP delivery were not performed yet. However, some promising results were already achieved.

Antimicrobial activity assays, showed that the peptides even in low concentrations (32 $\mu \mathrm{g} / \mathrm{mL}$ ) are able to kill bacteria after contact with the surface both in $1 \%$ human plasma presence and absence. This effect was superior for a higher peptide concentration. Both PU films showed good results, however, PU with MSI-78 (2-18) has higher antimicrobial activity. 
This was not expected, since in solution, MSI-78 (1-17) has a lower MIC than MSI-78 (2-18) to this bacterium, suggesting that MSI-78 (2-18) could have a faster release from the PU film.

As said before, these results are very positive, suggesting that incorporation of AMPs on PU may be a promising, simple and innovative way to produce materials with antimicrobial activity. However, more studies need to be performed in the future. It is important to characterize the surfaces, namely the alteration of their mechanical properties with increase of AMP concentration and their stability in physiological conditions and their hemocompatibility. Moreover, it will be necessary to evaluate the kinetic of peptide delivery from the surface that can be easily realized using fluorescent labeled AMPs.

As concluding remarks it is possible to say that this research work achieved most of its main goal, obtaining surfaces for blood contact with antimicrobial properties without inducing platelet adhesion and activation. However, although results were very promising, more studies need to be done in the future to evaluate their application as intravascular catheters coating. 


\section{Bibliography}

[1] L. a Mermel, M. Allon, E. Bouza, D. E. Craven, P. Flynn, N. P. O’Grady, I. I. Raad, B. J. a Rijnders, R. J. Sherertz, and D. K. Warren, "Clinical practice guidelines for the diagnosis and management of intravascular catheter-related infection: 2009 Update by the Infectious Diseases Society of America.," Clin. Infect. Dis., vol. 49, pp. 1-45, 2009.

[2] X. Li, P. Li, R. Saravanan, A. Basu, B. Mishra, S. H. Lim, X. Su, P. A. Tambyah, and S. S. J. Leong, "Antimicrobial functionalization of silicone surfaces with engineered short peptides having broad spectrum antimicrobial and salt-resistant properties." Acta Biomater., vol. 10, no. 1, pp. 258-266, 2014.

[3] B. D. Ratner, A. S. Hoffman, F. J. Schoen, and J. E. Lemons, Biomaterials Science, 2nd ed. 2004.

[4] C. Monteiro, M. Pinheiro, M. Fernandes, S. Maia, C. L. Seabra, F. Ferreira-Da-Silva, S. Reis, P. Gomes, and M. C. L. Martins, "A 17-mer Membrane-Active MSI-78 Derivative with Improved Selectivity toward Bacterial Cells.” Mol. Pharm., vol. 12, no. 8, pp. 2904-2911, 2015.

[5] S. M. de Witt, R. Verdoold, J. M. E. M. Cosemans, and J. W. M. Heemskerk, "Insights into platelet-based control of coagulation.”, Thromb. Res., vol. 133, pp. 39-48, 2014.

[6] M. D. Mitchell, B. J. Anderson, K. Williams, and C. a. Umscheid, "Heparin flushing and other interventions to maintain patency of central venous catheters: A systematic review." J. Adv. Nurs., vol. 65, no. 10, pp. 2007-2021, 2009.

[7] D. Campoccia, L. Montanaro, and C. R. Arciola, “A review of the biomaterials technologies for infection-resistant surfaces.” Biomaterials, vol. 34, no. 34, pp. 8533-8554, 2013.

[8] R. L. Skov and K. S. Jensen, “Community-associated meticillin-resistant Staphylococcus aureus as a cause of hospital-acquired infections." J. Hosp. Infect., vol. 73, no. 4, pp. 364-370, 2009.

[9] J. C. Hockenhull, K. Dwan, A. Boland, G. Smith, A. Bagust, Y. Dündar, C. Gamble, and C. Mcleod, "The clinical effectiveness and cost-effectiveness of central venous catheters treated with anti-infective agents in preventing bloodstream infections." Business, vol. 12, no. 12, 2008.

[10] L. Lombardi, G. Maisetta, G. Batoni, and A. Tavanti, "Insights into the Antimicrobial Properties of Hepcidins: Advantages and Drawbacks as Potential Therapeutic Agents." Molecules, vol. 20, no. 4, pp. 6319-6341, 2015.

[11] W. DF., “Osteointegration,” in "The Williams Dictionary of Biomaterials", L. U. Pree, 1999.

[12] J. McCabe and A. Walls, “Applied dental materials” BalckWell Publ. 9th Ed., 2008.

[13] J. Wong and J. Bonzino, "Biomaterials" CRC Press. USA, 2007.

[14] J. Temenoff and A. Mikos, "Biomaterials: The intersection of Biology and Materials Science" $2^{\text {nd }} E d ., 2004$.

[15] J. Davis, "Overview of biomaterials and their use in medical devices," in "Handbook of Materials for Medical Devices", A. I. A. T. P. Ltd, 2003.

[16] A. Von Recum, "Handbook of biomaterials evaluation - scientific, technical, and clinical testing of implant materials", T. \& Francis, 2nd Ed., 2005.

[17] G. Wnek and G. Bowlin, “Encyclopedia of biomaterials and biomedical engineering”, Informa Healthcare, vol. 3. 2008. 
[18] B. Ratner, A. Hoffman, and et al, "Biomaterials science: an introduction to materials in medicine”, Elsevier Acad. Press. 2nd Ed., 2004.

[19] S. Nandi, S. Roy, and E. Al, "Orthopedic applications of bone graft \& graft substitutes: a review," Indian J Med Res, vol. 132, pp. 15-30, 2010.

[20] M. Long and H. Rack, "Titanium alloys in total joint replacement - a materials science perspective," Biomaterials, vol. 19, pp. 1621-1639, 1998.

[21] S. Shalaby and U. Salz, "Polymers for dental and orthopedic applications" CRC Press. NY, vol. 1, 2007.

[22] D. Macocinschi, D. Filip, and S. Vlad, "Natural-Based Polyurethane Biomaterials for Medical Applications" 2006.

[23] J. a. Sauer, "Polymer Science and Technology", CRC Press NY, 2000.

[24] M. Akay, "Introduction to polymer science and technology", 2012.

[25] S. Ravi and E. L. Chaikof, "Biomaterials for vascular tissue engineering," Regen. Med., vol. 5, no. 1, pp. 1-21, 2010.

[26] J. Forcillo, M. Pellerin, L. P. Perrault, R. Cartier, D. Bouchard, P. Demers, and M. Carrier, "Carpentier-Edwards pericardial valve in the aortic position: 25-years experience," Ann. Thorac. Surg., vol. 96, no. 2, pp. 486-493, 2013.

[27] V. Sá, “Os polímeros como biomateriais,” pp. 48-54.

[28] S. Neuenschwander and S. P. Hoerstrup, "Heart valve tissue engineering," Transpl. Imunol., vol. 12, no. 3-4, pp. 359-365, 2004.

[29] Q. Tian, E. Takács, I. Krakovský, Z. E. Horváth, L. Rosta, and L. Almásy, "Study on the microstructure of polyester polyurethane irradiated in air and water," Polymers (Basel)., vol. 7, no. 9, pp. 1755-1766, 2015.

[30] C. Prisacariu, "Polyurethane elastomers: from morphology to mechanical aspects", 2011.

[31] J. V Cauich-rodríguez, L. H. Chan-chan, F. Hernandez-sánchez, and J. M. Cervantes-uc, "Degradation of Polyurethanes for Cardiovascular Applications" Adv. Biomater. Sci. Biomed. Appl., pp. 51-82, 2012.

[32] J. Guan, C. Gao, L. Feng, and J. Shen, "Surface modification of polyurethane for promotion of cell adhesion and growth 1 : Surface photo-grafting with $\mathrm{N}, \mathrm{N}$-dimethylaminoethyl methacrylate and cytocompatibility of the modified surface" J. Mater. Sci., vol. 12, pp. 447-452, 2001.

[33] I. J. Zdrahala, Richard J. Zdrahala, "Biomedical applications of PU. a review of past, promises, present realities, and a vibrant future” J. Biomater. Appl., vol. 14, pp. 67-90, 1999.

[34] P. Cotogni, "Focus on peripherally inserted central catheters in critically ill patients," World J. Crit. Care Med., vol. 3, no. 4, p. 80, 2014.

[35] P. Francois, "Physical and biological effects of a surface coating procedure on polyurethane catheters," Biomaterials, vol. 17, no. 7, pp. 667-678, 1996.

[36] I. Raad, H. Hanna, and D. Maki, "Intravascular catheter-related infections: advances in diagnosis, prevention and management," Lancet Infect. Dis., vol. 7, pp. 645-657, 2007. 
[37] N. P. O’Grady, M. Alexander, E. P. Dellinger, D. G. Maki, H. Masur, R. D. Mccormick, and L. a Mermel, "Guidelines for the Prevention of Intravascular Catheter- Related Infections," Clin. Infect. Dis., vol. 52, no. 9, pp. 162-193, 2011.

[38] N. O, "Guidelines for the Prevention of Intravascular Catheter" Clin. Infect. Dis., vol. 16, no. 11, pp. 177-1307, 2002.

[39] E. Barczykowska, "The Use of Central Venous Lines in the Treatment of Chronically Ill Children" pp. 1001-1009, 2014.

[40] M. Wagner, J. Bonhoeffer, T. O. Erb, R. Glanzmann, F. M. Häcker, M. Paulussen, D. Weibel, and U. Heininger, "Prospective study on central venous line associated bloodstream infections" Arch. Dis. Child., vol. 96, no. 9, pp. 827-831, 2011.

[41] “http://www.medscape.com/viewarticle/741411_4.”, accesed on 25/04/2016

[42] “https://www.cookmedical.com/products/cc_utlm3lp_webds/.”, accesed on 15/02/2016

[43] G. R. Doyle and J. A. McCutcheon, "Intravenous Fluid Therapy” in Clinical Procedures for Safer Patient Care, 2015.

[44] I. C. Gonçalves, M. C. L. Martins, J. N. Barbosa, P. Oliveira, M. a. Barbosa, and B. D. Ratner, "Platelet and leukocyte adhesion to albumin binding self-assembled monolayers" J. Mater. Sci. Mater. Med., vol. 22, no. 9, pp. 2053-2063, 2011.

[45] B. Krafte-Jacobs, C. J. Sivit, R. Mejia, and M. M. Pollack, "Catheter-related thrombosis in critically ill children: comparison of catheters with and without heparin bonding" J. Pediatr. vol. 126, no. 1, pp. 50-54, 1995.

[46] C. Sperling, M. Fischer, M. F. Maitz, and C. Werner, "Blood coagulation on biomaterials requires the combination of distinct activation processes" Biomaterials, vol. 30, no. 27, pp. 4447-4456, 2009.

[47] S. McKnight, "Nurse's guide to understanding and treating thrombotic occlusion of central venous access devices." MEDSURG Nurs., vol. 13, no. 6, pp. 377-383, 2004.

[48] R. R. Seeley, T. D. Stephens, and P. Tate, Anatomia e Fisiologia, 6a ed. 2003.

[49] R. I. Handin, S. E. Lux, and T. P. Stossel, "Blood-Principles and Practice of Hematology" $2^{\text {nd }}$ Ed., 2002

[50] S. Whittemore, "The Boold Composition," in "The human body: How it works-The circulatory System", p. 20, 2009,

[51] B. Savage, E. Saldívar, and Z. M. Ruggeri, "Initiation of Platelet Adhesion by Arrest onto Fibrinogen or Translocation on von Willebrand Factor," Cell, vol. 84, no. 2, pp. 289-297, 1996.

[52] B. Xie, R. Zhang, H. Zhang, A. Xu, Y. Deng, Y. Lv, F. Deng, and S. Wei, "Decoration of heparin and bovine serum albumin on polysulfone membrane assisted via polydopamine strategy for hemodialysis" J. Biomater. Sci. Polym. Ed., vol. 27, no. 9, pp. 880-897, 2016.

[53] "Biological evaluation of medical devices- Part 4: Selection of tests for interactions with blood" Int. Stand. ISO 10993-4.

[54] S. N. Rodrigues, I. C. Gonçalves, M. C. L. Martins, M. a. Barbosa, and B. D. Ratner, "Fibrinogen adsorption, platelet adhesion and activation on mixed hydroxyl-/methyl-terminated selfassembled monolayers" Biomaterials, vol. 27, no. 31, pp. 5357-5367, 2006. 
[55] P. B. Russell, J. Kline, M. C. Yoder, and R. a. Polin, "Staphylococcal adherence to polyvinyl chloride and heparin-bonded polyurethane catheters is species dependent and enhanced by fibronectin” J. Clin. Microbiol., vol. 25, no. 6, pp. 1083-1087, 1987.

[56] T. Petters, "All about Albumin-Biochemistry, Genetics and Medical Applications", 1996.

[57] M. Wang, C. Fu, X. Liu, Z. Lin, N. Yang, and S. Yu, "Probing the mechanism of plasma protein adsorption on Au and Ag nanoparticles with FT-IR spectroscopy" Nanoscale, vol. 7, no. 37, pp. 15191-15196, 2015.

[58] M. W. Mosesson, "Fibrinogen and fibrin structure and functions" J. Thromb. Haemost., vol. 3, no. 8, pp. 1894-1904, 2005.

[59] R. W. Colman, "Hemostasis and Thrombosis: Basic Principles and Clinical Practice", Lippincott Williams \& Wilkins, 2006.

[60] C. Jennewein, N. Tran, and K. Zacharowsky, "The Inflammatory Potential of Fibrin(ogen) and its Degradation Products," in Annual Update in Intensive Care and Emergency Medicine 2011, 2001, pp. 62-69.

[61] http://www.sigmaaldrich.com/life-science/metabolomics/enzyme-explorer/enzymereagents/human-albumin.html\#struct , accesed on 22/06/2016

[62] http://www.sigmaaldrich.com/life-science/metabolomics/enzyme-explorer/analyticalenzymes/fibrinogen-and-fibrin.html, accesed on 22/06/2016

[63] E. a. Vogler and C. a. Siedlecki, "Contact activation of blood-plasma coagulation," Biomaterials, vol. 30, no. 10, pp. 1857-1869, 2009.

[64] T. Halkier, "Mechanisms in Blood Coagulation, Fibrinolysis and the Complement System", Cambridge University Press, 1991.

[65] G. MB and S. MV, "Biomaterial-associated thrombosis: roles of coagulation factors, complement, platelets and leukocytes," Biomaterials, vol. 25, no. 26, 2004.

[66] M. Gawaz, "Role of platelets in coronary thrombosis and reperfusion of ischemic myocardium," Cardiovasc. Res., vol. 61, no. 3, pp. 498-511, 2004.

[67] M. Hoffman, D. M. Monroe, J. a Oliver, and H. R. Roberts, "Factors IXa and Xa play distinct roles in tissue factor-dependent initiation of coagulation.," Blood, vol. 86, no. 5, pp. 1794-1801, 1995.

[68] A.A. Maung and L. J. Kaplan, "Role of fibrinogen in massive injury" Minerva Anestesiol., vol. 80, no. 1, pp. 89-95, 2014.

[69] A. Coppola, M. Franchini, M. Makris, E. Santagostino, G. Di Minno, and P. M. Mannucci, "Thrombotic adverse events to coagulation factor concentrates for treatment of patients with haemophilia and von Willebrand disease: a systematic review of prospective studies" Haemophilia, vol. 18, no. 3, pp. e173-87, 2012.

[70] J. M. Stassen, J. Arnout, and H. Deckmyn, "The hemostatic system" Curr Med Chem, vol. 11, no. 17, pp. 2245-2260, 2004.

[71] G. Lugassy, "Thrombosis and antithrombotic therapy", London, 2001.

[72] I. Björk and U. Lindahl, "Mechanism of the anticoagulant action of heparin.," Mol. Cell. Biochem., vol. 48, no. 3, pp. 161-182, 1982. 
[73] J. C. Chapin and K. a. Hajjar, "Fibrinolysis and the control of blood coagulation," Blood Rev., vol. 29, no. 1, pp. 17-24, 2015.

[74] F. Arosa, E. M. Cardoso, and F. C. Pacheco, "Fundamentos de Imunologia", 2012.

[75] A. P. Kaplan and B. Ghebrehiwet, "The plasma bradykinin-forming pathways and its interrelationships with complement,” Mol. Immunol., vol. 47, no. 13, pp. 2161-2169, 2010.

[76] T. Hallström and K. Riesbeck, "Haemophilus influenzae and the complement system," Trends Microbiol., vol. 18, no. 6, pp. 258-265, 2010.

[77] M. Gawaz, "Blood Platelets: Physiology, Pathophysiology, Membrane Receptors, Antiplatelet Drugs, Coronary Heart Disease, Stroke, Peripheral Arterial", Thieme, 2001.

[78] I. C. Gonçalves, M. C. L. Martins, M. a. Barbosa, E. Naeemi, and B. D. Ratner, "Selective protein adsorption modulates platelet adhesion and activation to oligo(ethylene glycol)-terminated selfassembled monolayers with C18 ligands," J. Biomed. Mater. Res. - Part A, vol. 89, no. 3, pp. 642-653, 2009.

[79] M. Walden, J. M. Edwards, A. M. Dziewulska, R. Bergmann, G. Saalbach, S.-Y. Kan, O. K. Miller, M. Weckener, R. J. Jackson, S. L. Shirran, C. H. Botting, G. J. Florence, M. Rohde, M. J. Banfield, and U. Schwarz-Linek, "An internal thioester in a pathogen surface protein mediates covalent host binding," Elife, vol. 4, pp. 1-24, 2015.

[80] D. H. Farrell, P. Thiagarajan, D. W. Chung, and E. W. Davie, "Role of fibrinogen alpha and gamma chain sites in platelet aggregation," Proc. Natl. Acad. Sci. USA, vol. 89, no. November, pp. 10729-10732, 1992.

[81] F. Müller, N. J. Mutch, W. a Schenk, S. a Smith, H. M. Spronk, S. Schmidbauer, W. a Gahl, J. H. Morrissey, and T. Renné, "Platelet polyphosphates are proinflammatory and procoagulant mediators in vivo," Cell, vol. 139, no. 6, pp. 1143-1156, 2010.

[82] H. Hamzeh-Cognasse, P. Damien, A. Chabert, B. Pozzetto, F. Cognasse, and O. Garraud, "Platelets and Infections - Complex Interactions with Bacteria," Front. Immunol., vol. 6, no. February, pp. 1-18, 2015.

[83] “http://platelets.se/biomaterial/”, accessed on 13/03/2016

[84] J. N. Barbosa, M. a Barbosa, and A. P. Aguas, "Adhesion of human leukocytes to biomaterials: an in vitro study using alkanethiolate monolayers with different chemically functionalized surfaces" J. Biomed. Mater. Res. A, vol. 65, no. 4, pp. 429-434, 2003.

[85] M. R. Brunstedt, J. M. Anderson, K. L. Spilizewski, R. E. Marchant, and a Hiltner, "In vivo leucocyte interactions on Pellethane surfaces" Biomaterials, vol. 11, no. 6, pp. 370-8, 1990.

[86] V. a. Tegoulia and S. L. Cooper, "Leukocyte adhesion on model surfaces under flow: Effects of surface chemistry, protein adsorption, and shear rate” J. Biomed. Mater. Res., vol. 50, pp. 291$301,2000$.

[87] S. E. Cramton, C. Gerke, N. F. Schnell, W. W. Nichols, and F. Gotz, "The Intercellular Adhesion (ica) Locus Is Present in Staphylococcus aureus and Is Required for Biofilm Formation" Infect. Immun., vol. 67, no. 10, pp. 5427-5433, 1999.

[88] M. A. das Neves, R. C. Melo, A. M. de Oliveira Goes, T. R. Protta, C. C. de Almeida, A. R. Fernandes, A. Petnys, and E. Raboni, "Infecções em cateteres venosos centrais de longa permanência: Revisão da literatura” J. Vasc. Bras., vol. 9, no. 1, pp. 46-50, 2010.

[89] J. Rello, a Ochagavia, and E. Sabanes, "Evaluation of outcome of intravenous catheter-related infections in critically ill patients" Am J Respir Crit Care Med, vol. 162, pp. 1027-30, 2000. 
[90] K. Ouriel, "Preventing complications of central venous catheterization” N. Engl. J. Med., vol. 348, no. 26, pp. 2684-2686; author reply 2684-2686, 2003.

[91] H. V Patil, V. C. Patil, M. N. Ramteerthkar, and R. D. Kulkarni, “Central venous catheter-related bloodstream infections in the intensive care unit" Indian J. Crit. Care Med., vol. 15, no. 4, pp. 213-23, 2011.

[92] G. O. Toole, H. B. Kaplan, and R. Kolter, "Biofilm Formation as Microbial Development" Annu. Rev. Microbiol., pp. 49-79, 2000.

[93] T. Moriarty, A. Poulsson, E. Rochford, and R. Richards, "Bacterial Adhesion and Biomaterial Surfaces” Compr. Biomater., vol. 4, pp. 75-100, 2011.

[94] T. R. Garrett, M. Bhakoo, and Z. Zhang, "Bacterial adhesion and biofilms on surfaces" Prog. Nat. Sci., vol. 18, no. 9, pp. 1049-1056, 2008.

[95] N. P. Boks, W. Norde, H. C. van der Mei, and H. J. Busscher, "Forces involved in bacterial adhesion to hydrophilic and hydrophobic surfaces" Microbiology, vol. 154, no. 10, pp. 3122 3133, 2008.

[96] G. Gao, K. Yu, J. Kindrachuk, D. E. Brooks, R. E. W. Hancock, and J. N. Kizhakkedathu, "Antibacterial Surfaces Based on Polymer Brushes: Investigation on the Influence of Brush Properties on Antimicrobial Peptide Immobilization and Antimicrobial Activity Antibacterial Surfaces Based on Polymer Brushes : Investigation on the Influence of Brushes” Biomacromolecules, 2011.

[97] J. L. Balcázar, J. Subirats, and C. M. Borrego, "The role of biofilms as environmental reservoirs of antibiotic resistance" Front. Microbiol., vol. 6, no. OCT, pp. 1-9, 2015.

[98] J. D. Bryers, “Medical Biofilms” Biotechnol. Bioeng., vol. 100, no. 1, pp. 1-18, 2008.

[99] B. Deslouches, K. Islam, J. K. Craigo, S. M. Paranjape, R. C. Montelaro, and T. a. Mietzner, "Activity of the de novo engineered antimicrobial peptide WLBU2 against Pseudomonas aeruginosa in human serum and whole blood: Implications for systemic applications" Antimicrob. Agents Chemother., vol. 49, no. 8, pp. 3208-3216, 2005.

[100] S. E. Abed, S. K. Ibnsouda, H. Latrache, and F. Hamadi, "Scanning Electron Microscopy (SEM) and Environmental SEM : Suitable Tools for Study of Adhesion Stage and Biofilm Formation" Scan. Electron Microsc., pp. 717-730, 2008.

[101] R. Coico, “Gram Stain,” in "Current Protocols in Microbiology", I. John Wiley \& Sons, Ed. 2005, p. 1550.

[102] L. Brown, J. M. Wolf, R. Prados-Rosales, and A. Casadevall, "Through the wall: extracellular vesicles in Gram-positive bacteria, mycobacteria and fungi" Nat. Rev. Microbiol., vol. 13, no. 10, pp. 620-30, 2015.

[103] M. a Kohanski, D. J. Dwyer, and J. J. Collins, "How antibiotics kill bacteria: from targets to networks" Nat. Rev. Microbiol., vol. 8, no. 6, pp. 423-35, 2010.

[104] R. Nazareth, J. Gonçalves-Pereira, a Tavares, M. Miragaia, H. de Lencastre, J. Silvestre, P. Freitas, E. Gonçalves, F. Martins, V. Mendes, C. Tapadinhas, and P. Póvoa, "Communityassociated methicillin-resistant Staphylococcus aureus infection in Portugal" Rev. Port. Pneumol., vol. 18, no. 1, pp. 34-8, 2012.

[105] M. S. Wilke, A. L. Lovering, and N. C. Strynadka, "B-Lactam antibiotic resistance: a current structural perspective” Curr. Opin. Microbiol., vol. 8, no. 5, pp. 525-533, 2005.

[106] W. F. C. Ferreira and J. C. F. De Sousa, "Microbiologia",LIDEL- edições técnicas, 1998. 
[107] G. Ramsey, "Staphylococcus aureus Bacteremia in Patients with Hickman Catheters" 1990.

[108] A. E. Namvar, "Clinical characteristics of Staphylococcus epidermidis : a systematic review" GMS Hyg. Infect. Control, vol. 9, no. 3, pp. 1-10, 2014.

[109] M. Otto, "Staphylococcus epidermidis-the'accidental'pathogen" Nat. Rev. Microbiol., vol. 7, no. 8, pp. 555-567, 2009.

[110] G. Villatte, C. Massard, S. Descamps, Y. Sibaud, C. Forestier, and K. Awitor, "Photoactive TiO 2 antibacterial coating on surgical external fixation pins for clinical application” pp. 3367-3375, 2015.

[111] M. Otto, “Molecular basis of Staphylococcus epidermidis infections" vol. 34, no. 2, pp. 201-214, 2012.

[112] “National Nosocomial Infections Surveillance, Public Health Service, System Report data summary from January 1992 through June 2004, issued October 2004,” 2004.

[113] C. J. Van Oss, "Long-range and short-range mechanisms of hydrophobic attraction and hydrophilic repulsion in specific and aspecific interactions," J. Mol. Recognit., vol. 16, no. 4, pp. 177-190, 2003.

[114] G. Cheng, Z. Zhang, S. Chen, J. D. Bryers, and S. Jiang, "Inhibition of bacterial adhesion and biofilm formation on zwitterionic surfaces," Biomaterials, vol. 28, no. 29, pp. 4192-4199, 2007.

[115] J. B. Schlenoff, "Zwitteration: Coating surfaces with zwitterionic functionality to reduce nonspecific adsorption” Langmuir, vol. 30, no. 32, pp. 9625-9636, 2014.

[116] F. Poncin-Epaillard, T. Vrlinic, D. Debarnot, M. Mozetic, A. Coudreuse, G. Legeay, B. El Moualij, and W. Zorzi, "Surface Treatment of Polymeric Materials Controlling the Adhesion of Biomolecules" J. Funct. Biomater., vol. 3, no. 3, pp. 528-543, 2012.

[117] A. Rai, S. Pinto, M. B. Evangelista, H. Gil, S. Kallip, M. G. S. Ferreira, and L. Ferreira, “Highdensity antimicrobial peptide coating with broad activity and low cytotoxicity against human cells" Acta Biomater., vol. 33, pp. 64-77, 2016.

[118] F. M. T. a Costa, S. R. Maia, P. a C. Gomes, and M. C. L. Martins, "Dhvar5 antimicrobial peptide (AMP) chemoselective covalent immobilization results on higher antiadherence effect than simple physical adsorption" Biomaterials, vol. 52, pp. 531-8, 2015.

[119] A. Friedman and J. Friedman, "New biomaterials for the sustained release of nitric oxide: past, present and future” Expert Opin. Drug Deliv., vol. 6, no. 10, pp. 1113-22, 2009.

[120] H. McCarthy, J. K. Rudkin, N. S. Black, L. Gallagher, E. O’Neill, and J. P. O'Gara, “Methicillin resistance and the biofilm phenotype in Staphylococcus aureus" Front. Cell. Infect. Microbiol., vol. 5, no. January, pp. 1-9, 2015.

[121] K. Bazaka, M. V. Jacob, W. Chrzanowski, and K. Ostrikov, "Anti-bacterial surfaces: natural agents, mechanisms of action, and plasma surface modification” RSC Adv., vol. 5, no. 60, pp. 48739-48759, 2015.

[122] G. Zhang, C. R. Ross, and F. Blecha, "Porcine antimicrobial peptides: New prospects for ancient molecules of host defense” Vet. Res., vol. 31, no. 3, pp. 277-296, 2000.

[123] S. a Onaizi and S. S. J. Leong, "Tethering antimicrobial peptides: current status and potential challenges” Biotechnol. Adv., vol. 29, no. 1, pp. 67-74, 2011. 
[124] M. Férnandez-Vidal, S. Jayasinghe, A. Ladokhin, and S. White, "Folding amphipathic helices into membranes: amphiphilicity trumps hydrophobicity” J. Mol. Biol., vol. 370, no. 3, pp. 459-470, 2007.

[125] X. Zhu, N. Dong, Z. Wang, Z. Ma, L. Zhang, Q. Ma, and A. Shan, "Design of imperfectly amphipathic a-helical antimicrobial peptides with enhanced cell selectivity" Acta Biomater., vol. 10, no. 1, pp. 244-257, 2014.

[126] A. Bahar and D. Ren, “Antimicrobial Peptides” Pharmaceuticals, vol. 6, no. 12, pp. 1543-1575, 2013.

[127] R. E. W. Hancock and H.-G. Sahl, "Antimicrobial and host-defense peptides as new anti-infective therapeutic strategies” Nat. Biotechnol., vol. 24, no. 12, pp. 1551-1557, 2006.

[128] G. Wang, B. Mishra, K. Lau, T. Lushnikova, R. Golla, and X. Wang, "Antimicrobial Peptides in 2014" Pharmaceuticals, vol. 8, no. 1, pp. 123-150, 2015.

[129] R. B. Merrifield, P. Juvvadi, D. Andreu, J. Ubach, a Boman, and H. G. Boman, "Retro and Retroenantio Analogs of Cecropin Melittin Hybrids," Proceedings of the National Academy of Sciences of the United States of America, vol. 92, no. 8. pp. 3449-3453, 1995.

[130] G. Wang, “Human Antimicrobial Peptides and Proteins" Pharmaceuticals, vol. 7, no. 5, pp. 545594, 2014.

[131] B. M. Peters, M. E. Shirtliff, and M. A. Jabra-Rizk, "Antimicrobial peptides: Primeval molecules or future drugs?” PLoS Pathog., vol. 6, no. 10, pp. 4-7, 2010.

[132] N. K. Brogden and K. A. Brogden, "Will new generations of modified antimicrobial peptides improve their potential as pharmaceuticals?",IntJourAntimicrobial Agents, vol.38, no.3,pp. 277 225, 2011.

[133] W. E. Robinson, B. McDougall, D. Tran, and M. E. Selsted, "Anti-HIV-1 activity of indolicidin, an antimicrobial peptide from neutrophils” J. Leukoc. Biol., vol. 63, no. 1, pp. 94-100, 1998.

[134] M. Pushpanathan, J. Rajendhran, S. Jayashree, B. Sundarakrishnan, S. Jayachandran, and P. Gunasekaran, "Identification of a Novel Antifungal Peptide with Chitin-Binding Property from Marine Metagenome” Protein Pept. Lett., vol. 19, no. 12, pp. 1289-1296, 2012.

[135] J. Alberola, a Rodriguez, O. Francino, X. Roura, L. Rivas, and D. Andreu, "Safety and efficacy of antimicrobial peptides against naturally acquired leishmaniasis" Antimicrob Agents Chemother, vol. 48, no. 2, pp. 641-643, 2004.

[136] S. Sharma, N. Sahoo, and A. Bhunia, “Antimicrobial Peptides and their Pore / Ion Channel Properties in Neutralization of Pathogenic Microbes" pp. 46-53, 2016.

[137] G. Zhao, H. Zhong, M. Zhang, and Y. Hong, "Effects of antimicrobial peptides on Staphylococcus aureus growth and biofilm formation in vitro following isolation from implant-associated infections" Int. J. Clin. Exp. Med., vol. 8, no. 1, pp. 1546-51, 2015.

[138] F. Costa, I. F. Carvalho, and R. C. Montelaro, "Covalent immobilization of antimicrobial peptides (AMPs) onto biomaterial surfaces," Acta Biomater., vol. 7, no. 4, pp. 1431-1440, 2011.

[139] W. C. Wimley, "Describing the Mechanism of Antimicrobial Peptide Action with the Interfacial Activity Model” vol. 5, no. 10, pp. 905-917, 2011.

[140] B. Bechinger and K. Lohner, "Detergent-like actions of linear amphipathic cationic antimicrobial peptides” Biochim. Biophys. Acta-Biomembr., vol. 1758, no. 9, pp. 1529-1539, 2006. 
[141] T. Lee, K. N. Hall, and M. Aguilar, “Antimicrobial Peptide Structure and Mechanism of Action : A Focus on the Role of Membrane Structure” pp. 25-39, 2016.

[142] M. R. Yeaman and N. Y. Yount, "Mechanisms of Antimicrobial Peptide Action and Resistance" vol. 55, no. 1, pp. 27-55, 2003.

[143] E. Mataraci and S. Dosler, "In Vitro Activities of Antibiotics and Antimicrobial Cationic Peptides Alone and in Combination against Methicillin-Resistant Staphylococcus aureus Biofilms" Antimicrob. Agents Chemother., vol. 56, no. 12, pp. 6366-6371, 2012.

[144] D. Alves and M. Olívia Pereira, "Mini-review: Antimicrobial peptides and enzymes as promising candidates to functionalize biomaterial surfaces" Biofouling, vol. 30, no. 4, pp. 483-499, 2014.

[145] K. Braun, A. Pochert, M. Lindén, M. Davoudi, A. Schmidtchen, R. Nordström, and M. Malmsten, "Membrane interactions of mesoporous silica nanoparticles as carriers of antimicrobial peptides" J. Colloid Interface Sci., vol. 475, pp. 161-170, 2016.

[146] C. K. Bower, M. a. Daeschel, and J. McGuire, "Protein antimicrobial barriers to bacterial adhesion” J. Dairy Sci., vol. 81, no. 10, pp. 2771-8, 1998.

[147] D. Gopinath, M. Senthil Kumar, D. Selvaraj, and R. Jayakumar, "Pexiganan-incorporated collagen matrices for infected wound-healing processes in rat” J. Biomed. Mater. Res. - Part A, vol. 73, no. 3, pp. 320-331, 2005.

[148] C. Faber, H. P. Stallmann, D. M. Lyaruu, U. Joosten, C. Von Eiff, A. Van Nieuw Amerongen, and P. I. J. M. Wuisman, "Comparable efficacies of the antimicrobial peptide human lactoferrin 1-11 and gentamicin in a chronic methicillin-resistant Staphylococcus aureus osteomyelitis model," Antimicrob. Agents Chemother., vol. 49, no. 6, pp. 2438-2444, 2005.

[149] F. Costa, I. F. Carvalho, R. C. Montelaro, P. Gomes, and M. C. L. Martins, "Covalent immobilization of antimicrobial peptides (AMPs) onto biomaterial surfaces," Acta Biomater., vol. 7, no. 4, pp. 1431-1440, 2011.

[150] R. R. Silva, K. Y. P. S. Avelino, K. L. Ribeiro, O. L. Franco, M. D. L. Oliveira, and C. A. S. Andrade, "Chemical immobilization of antimicrobial peptides on biomaterial surfaces" no. 3 , pp. 129-142, 2016.

[151] H. Murata, R. R. Koepsel, K. Matyjaszewski, and A. J. Russell, "Permanent, non-leaching antibacterial surfaces-2: How high density cationic surfaces kill bacterial cells" Biomaterials, vol. 28, no. 32, pp. 4870-4879, 2007.

[152] M. Bagheri, M. Beyermann, and M. Dathe, "Immobilization reduces the activity of surface-bound cationic antimicrobial peptides with no influence upon the activity spectrum" Antimicrob. Agents Chemother., vol. 53, no. 3, pp. 1132-1141, 2009.

[153] M. Gabriel, K. Nazmi, E. C. Veerman, A. V. N. Amerongen, and A. Zentner, "Preparation of LL37-grafted titanium surfaces with bactericidal activity” Bioconjug. Chem., vol. 17, no. 2, pp. 548-550, 2006.

[154] W. M. Cho, B. P. Joshi, H. Cho, and K. H. Lee, "Design and synthesis of novel antibacterial peptide-resin conjugates” Bioorg. Med. Chem. Lett., vol. 17, pp. 5772-5776, 2007.

[155] F. Costa, S. Maia, J. Gomes, P. Gomes, and M. C. L. Martins, "Characterization of hLF1-11 immobilization onto chitosan ultrathin films, and its effects on antimicrobial activity" Acta Biomater., vol. 10, no. 8, pp. 3513-3521, 2014.

[156] C. Edlund, M. Hedberg, A. Engström, J.-I. Flock, and D. Wade, “Antianaerobic activity of a cecropin-melittin peptide” Clin. Microbiol. Infect., vol. 4, no. 4, pp. 181-185, 1998. 
[157] B. Bechinger, "The structure, dynamics and orientation of antimicrobial peptides in membranes by multidimensional solid-state NMR spectroscopy," Biochim. Biophys. Acta-Biomembr., vol. 1462, no. 1-2, pp. 157-183, 1999.

[158] B. Bechinger, "Structure and functions of channel-forming peptides: Magainins, cecropins, melittin and alamethicin," J. Membr. Biol., vol. 156, pp. 197-211, 1997.

[159] H. Choi, Z. Yang, and J. C. Weisshaar, "Single-cell, real-time detection of oxidative stress induced in Escherichia coli by the antimicrobial peptide CM15," Proc. Natl. Acad. Sci., vol. 112, no. 3, pp. E303-E310, 2015.

[160] L. F. Leandro, C. a Mendes, L. a Casemiro, a H. C. Vinholis, W. R. Cunha, R. De Almeida, and C. H. G. Martins, "Antimicrobial activity of apitoxin, melittin and phospholipase A2 of honey bee (Apis mellifera) venom against oral pathogens," An. Acad. Bras. Cienc., vol. 87, no. 1, pp. 147155, 2015.

[161] P. Losada-Pérez, M. Khorshid, C. Hermans, T. Robijns, M. Peeters, K. L. Jiménez-Monroy, L. T. $\mathrm{N}$. Truong, and P. Wagner, "Melittin disruption of raft and non-raft-forming biomimetic membranes: A study by quartz crystal microbalance with dissipation monitoring.," Colloids Surf. B. Biointerfaces, vol. 123, pp. 938-944, 2014.

[162] I. AL-Ani, S. Zimmermann, J. Reichling, and M. Wink, "Pharmacological synergism of bee venom and melittin with antibiotics and plant secondary metabolites against multi-drug resistant microbial pathogens," Phytomedicine, vol. 22, no. 2, pp. 245-255, 2015.

[163] A. Giacometti, O. Cirioni, W. Kamysz, G. D’Amato, C. Silvestri, M. S. Del Prete, J. Łukasiak, and G. Scalise, "Comparative activities of cecropin A, melittin, and cecropin A-melittin peptide CA(1-7)M(2-9)NH2 against multidrug-resistant nosocomial isolates of Acinetobacter baumannii," Peptides, vol. 24, no. 9, pp. 1315-8, 2003.

[164] H. G. Boman, D. Wade, I. a Boman, B. Wåhlin, and R. B. Merrifield, “Antibacterial and antimalarial properties of peptides that are cecropin-melittin hybrids.," FEBS Lett., vol. 259, no. 1, pp. 103-106, 1989.

[165] L. Cavallarin, D. Andreu, and B. San Segundo, "Cecropin A-derived peptides are potent inhibitors of fungal plant pathogens.," Mol. Plant. Microbe. Interact., vol. 11, no. 3, pp. 218-227, 1998.

[166] S. Ji, W. Li, L. Zhang, Y. Zhang, and B. Cao, "Cecropin A-melittin mutant with improved proteolytic stability and enhanced antimicrobial activity against bacteria and fungi associated with gastroenteritis in vitro.," Biochem. Biophys. Res. Commun., vol. 451, no. 4, pp. 650-5, 2014.

[167] M. Wachinger, A. Kleinschmidt, D. Winder, N. Von Pechmann, A. Ludvigsen, M. Neumann, R. Holle, B. Salmons, V. Erfle, and R. Brack-Werner, "Antimicrobial peptides melittin and cecropin inhibit replication of human immunodeficiency virus 1 by suppressing viral gene expression," $J$. Gen. Virol., vol. 79, no. 4, pp. 731-740, 1998.

[168] “http://www.chemicalbook.com/ChemicalProductProperty_EN_CB3242575.htm”, accessed on 02/04/2016

[169] Y. Ge, D. L. Macdonald, K. J. Holroyd, C. Thornsberry, H. Wexler, M. Zasloff, and D. L. M. a C. Donald, "In Vitro Antibacterial Properties of Pexiganan , an Analog of Magainin In Vitro Antibacterial Properties of Pexiganan, an Analog of Magainin," vol. 43, no. 4, pp. 782-788, 1999.

[170] B. A. Lipsky, K. J. Holroyd, and M. Zasloff, “Topical versus Systemic Antimicrobial Therapy for Treating Mildly Infected Diabetic Foot Ulcers: A Randomized, Controlled, Double-Blinded, Multicenter Trial of Pexiganan Cream," Clin. Infect. Dis., vol. 47, no. 12, pp. 1537-1545, 2008. 
[171] L. M. Gottler and A. Ramamoorthy, "Structure, Membrane Orientation, Mechanism, and Function of Pexiganan - A Highly Potent Antimicrobial Peptide Designed From Magainin,” Biochim Biophys Acta., vol. 1788, no. 8, pp. 1680-1686, 2009.

[172] A. Ramamoorthy, S. Thennarasu, D.-K. Lee, A. Tan, and L. Maloy, "Solid-state NMR investigation of the membrane-disrupting mechanism of antimicrobial peptides MSI-78 and MSI-594 derived from magainin 2 and melittin.," Biophys. J., vol. 91, no. 1, pp. 206-16, 2006.

[173] F. Porcelli, B. a. Buck-Koehntop, S. Thennarasu, A. Ramamoorthy, and G. Veglia, "Structures of the dimeric and monomeric variants of magainin antimicrobial peptides (MSI-78 and MSI-594) in micelles and bilayers, determined by NMR spectroscopy," Biochemistry, vol. 45, no. 18, pp. 5793-5799, 2006.

[174] “http://www.chemicalbook.com/ProductChemicalPropertiesCB71179476_EN.htm”, accessed on $15 / 06 / 2016$

[175] R. F. Egerton, Physical principles of electron microscopy, vol. 8, no. 12. 2005.

[176] “http://www.britannica.com/technology/scanning-electron-microscope”, accessed on $18 / 06 / 2016$

[177] Y. Yuan and T. R. Lee, "Surface Science Techniques," G. Bracco and B. Holst, Eds. 2013.

[178] G. Bhutani, K. Muralidhar, and S. Khandekar, "Determination ofapparent contact angle and shape of a static pendant drop on a physically textured inclined surface," vol. 1, no. 1, pp. 2949, 2013.

[179] “http://www.ramehart.com/contactangle.htm”, accessed on 18/06/2016

[180] R. M. A. Azzam and N. M. Bashara, Ellipsometry and Polarized Light. 1987.

[181] “http://www.azom.com/article.aspx?ArticleID=3755”, accessed on 18/06/2016

[182] “http://faculty.chem.queensu.ca/people/faculty/horton/research.html”, accessed on $17 / 06 / 2016$

[183] T. Nicolet and C. All, "Introduction to Fourier Transform Infrared Spectrometry," A Thermo Electron Bussines, pp. 1-8, 2001.

[184] S. G. Kazarian and K. L. A. Chan, "ATR-FTIR spectroscopic imaging: recent advances and applications to biological systems," Analyst, vol. 138, no. 7, p. 1940, 2013.

[185] “http: //www.azom.com/article.aspx?ArticlelD=5958”, accessed on 17/06/2016

[186] M. C. Dixon, "Quartz crystal microbalance with dissipation monitoring: Enabling real-time characterization of biological materials and their interactions," J. Biomol. Tech., vol. 19, no. 3, pp. 151-158, 2008.

[187] “http://www.biolinscientific.com/”, accessed on 21/06/2016

[188] R. P. Richter, K. B. Rodenhausen, N. B. Eisele, and M. Schubert, Coupling Spectroscopic Ellipsometry and Quartz Crystal Microbalance to Study Organic Films at the Solid-Liquid Interface, vol. 52, no. January. 2014.

[189] K. Gayad, C. Henry, and T. Owen, “http://www.google.com/patents/EP0891998A1?cl=en," 1999. 
[190] M. C. L. Martins, D. Wang, J. Ji, L. Feng, and M. a. Barbosa, "Albumin and fibrinogen adsorption on PU-PHEMA surfaces,” Biomaterials, vol. 24, no. 12, pp. 2067-2076, 2003.

[191] M. C. L. Martins, B. D. Ratner, and M. a Barbosa, "Protein adsorption on mixtures of hydroxyland methyl-terminated alkanethiols self-assembled monolayers.," J. Biomed. Mater. Res. A, vol. 67, no. 1, pp. 158-71, 2003.

[192] J. Turkevich, S. P.C., and H. J, "A study of the nucleation and growth processes in the synthesis of colloidal gold," Discuss. Faraday Soc., vol. 11, no. 0, pp. 55-75, 1951.

[193] L. Ferreira, M. B. Evangelista, M. C. L. Martins, P. L. Granja, J. L. Esteves, and M. a. Barbosa, "Improving the adhesion of poly(ethylene terephthalate) fibers to poly(hydroxyethyl methacrylate) hydrogels by ozone treatment: Surface characterization and pull-out tests," Polymer (Guildf)., vol. 46, no. 23, pp. 9840-9850, 2005.

[194] P. Parreira, a. Magalhães, C. a. Reis, T. Borén, D. Leckband, and M. C. L. Martins, "Bioengineered surfaces promote specific protein-glycan mediated binding of the gastric pathogen Helicobacter pylori," Acta Biomater., vol. 9, no. 11, pp. 8885-8893, 2013.

[195] P. Pallavicini, A. Taglietti, G. Dacarro, Y. Antonio Diaz-Fernandez, M. Galli, P. Grisoli, M. Patrini, G. Santucci De Magistris, and R. Zanoni, "Self-assembled monolayers of silver nanoparticles firmly grafted on glass surfaces: Low Ag+ release for an efficient antibacterial activity," J. Colloid Interface Sci., vol. 350, no. 1, pp. 110-116, 2010.

[196] B. Marczak, B. Butruk, and T. Ciach, "Functionalization of polyurethane surfaces for further attachment of bioactive molecules Biomedical Engineering," Challenges Mod. Technol., vol. 4, no. 4, pp. 9-13, 2012.

[197] J. a Olmos-Asar, M. Ludueña, and M. M. Mariscal, "Monolayer protected gold nanoparticles: the effect of the headgroup-Au interaction.," Phys. Chem. Chem. Phys., vol. 16, no. 30, pp. 1597987, 2014.

[198] K. Tingey, J. Andrade, C. M. Jr, and R. Zdrahala, "Surface analysis of commercial biomedical polyurethanes," in Polymer surface dynamics, Andrade and E. JD, Eds. Press, New York: Plenum, 1988, p. 153.

[199] N. Lamba, K. Woodhouse, and S. Cooper, Polyurethanes in biomedical applications. Boca Raton, FL, USA, 1998.

[200] J. Bandekar and a Sawyer, "FT-IR spectroscopic studies of polyurethanes: IV. Studies of the effect of the presence of processing aids on the hemocompatibility of polyurethanes.," J. Biomater. Sci. Polym. Ed., vol. 7, no. 6, pp. 485-501, 1995.

[201] M. MCL, S. S, A. JC, and B. MA., "Protein Adsorption Characterization," in Methods in Molecular Biology, "Nanotechnology in Regenerative Medicine: Methods and Protocols," J. A. Planell and M. Navarro, Eds. San Diego, CA, USA: Human Press (Springer Science \& Business Media) USA Academic Press Inc., 2012.

[202] S. Schuster, W. Yu, M. Nega, Y. Y. Chu, S. Zorn, F. Zhang, F. Götz, and F. Schreiber, "The role of serum proteins in Staphylococcus aureus adhesion to ethylene glycol coated surfaces," Int. $J$. Med. Microbiol., vol. 304, no. 8, pp. 949-957, 2014.

[203] S. Chen, L. Li, C. Zhao, and J. Zheng, "Surface hydration: Principles and applications toward low-fouling/nonfouling biomaterials," Polymer (Guildf)., vol. 51, no. 23, pp. 5283-5293, 2010.

[204] X. Ding, J. Boney-montoya, B. M. Owen, A. L. Bookout, C. Coate, D. J. Mangelsdorf, and S. a Kliewer, "Protein Adsorption in Three Dimensions," Biomaterials, vol. 33, no. 5, pp. 1201-1237, 2013. 
[205] D. Eroshenko, I. Morozov, and V. Korobov, "The Role of Plasma, Albumin, and Fibronectin in Staphylococcus epidermidis Adhesion to Polystyrene Surface," Curr. Microbiol., vol. 70, no. 6, pp. 846-853, 2015.

[206] H. Maleki, A. Rai, S. Pinto, M. Evangelista, R. M. S. Cardoso, C. Paulo, T. Carvalheiro, A. Paiva, M. Imani, A. Simchi, L. Durães, A. Portugal, and L. Ferreira, "High Antimicrobial Activity and Low Human Cell Cytotoxicity of Core-Shell Magnetic Nanoparticles Functionalized with an Antimicrobial Peptide.," ACS Appl. Mater. Interfaces, 2016. 